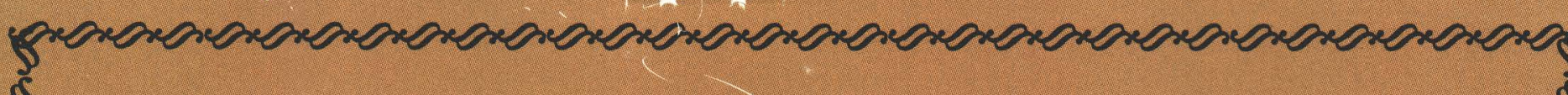

\title{
,
}

है

(1)

(1)

(1)

(5) \section{Surface-Water Contamination and Remediation in the Area from Denver to Idaho Springs, Colorado}

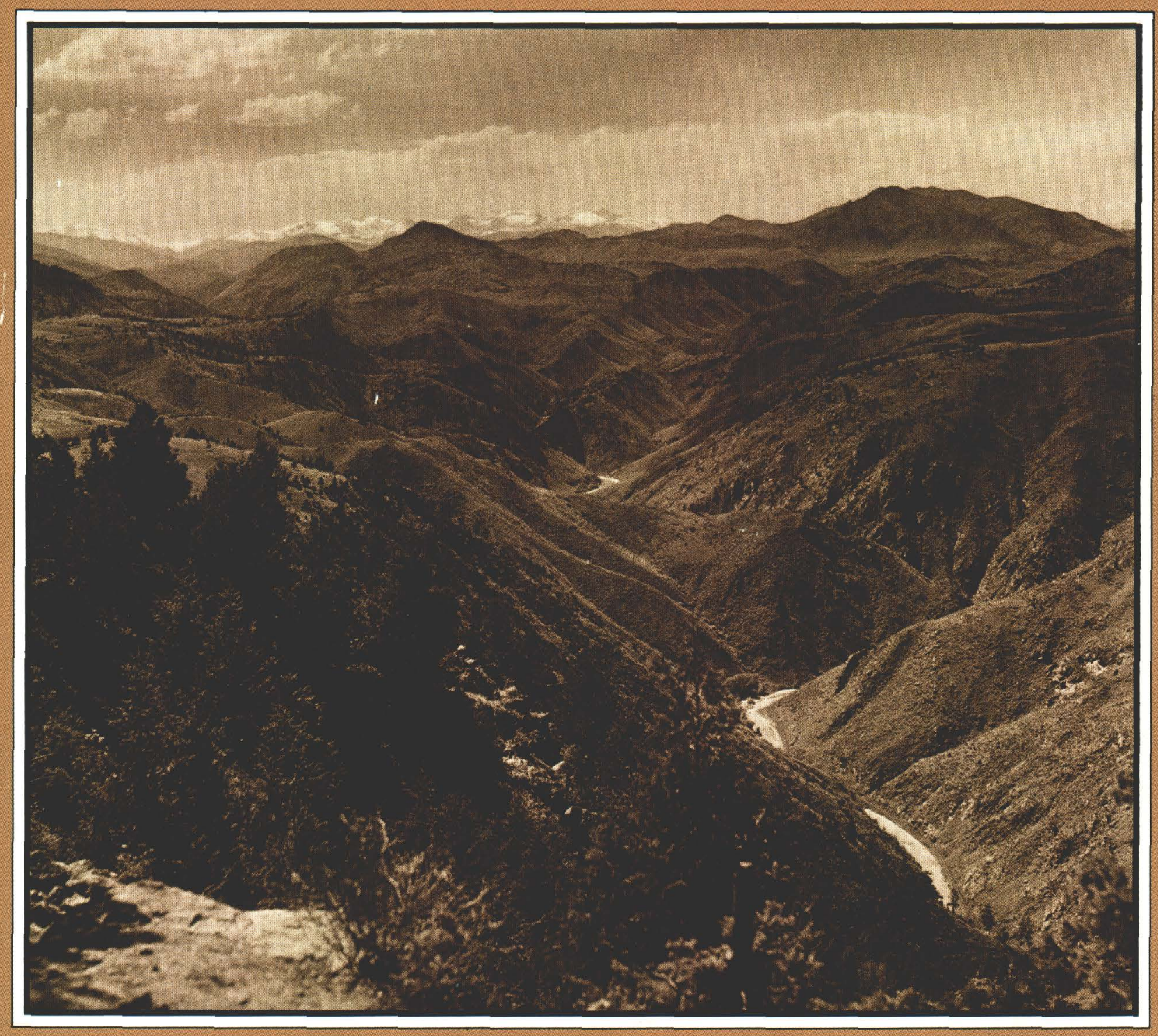

U.S. GEOLOGICAL SURVEY CIRCULAR 1097 
Cover:

View of Clear Creek Canyon prior to 1935 from Lookout Mountain. Railroad tracks are visible alongside the creek. Photograph by L. C. McClure, Denver Public Library Western History Collection (printed with permission). 


\section{Guidebook on the Geology, History, and Surface-Water Contamination and Remediation in the Area from Denver to Idaho Springs, Colorado}

Edited by K.C. Stewart and R.C. Severson

Written contributions by

\author{
U.S. Geological Survey \\ Walter H. Ficklin \\ Helen W. Folger \\ Wallace R. Hansen \\ Ralph R. Shroba \\ Kathleen S. Smith \\ Kathleen C. Stewart
}

Photographic contributions by

John M. Epperson

Larry P. Gough

Thomas Kohnen

Geoffrey S. Plumlee

Richard B. Tripp

\author{
Colorado School of Mines \\ Ronald R. Cohen \\ John C. Emerick \\ Ronald W. Klusman \\ Thomas R. Wildeman
}

Graphics by Michael F. Duncan, Margo L. Johnson, Shawn K. Smith, and Richard P. Walker Editorial assistance by Thomas Kohnen.

U.S. Geological Survey Circular 1097

\author{
Colorado School of Mines \\ Colorado Department of Transportation \\ Denver Post \\ Denver Public Library \\ Idaho Springs Historical Society \\ U.S. Geological Survey
}

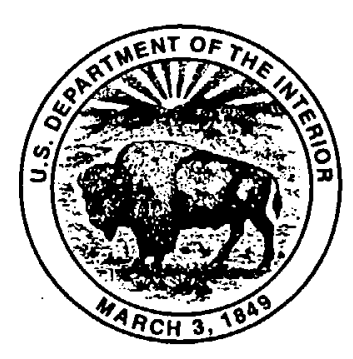




\title{
U.S. DEPARTMENT OF THE INTERIOR \\ BRUCE BABBITT, Secretary
}

\author{
U.S. GEOLOGICAL SURVEY
}

Gordon P. Eaton, Director

\author{
Free on application to U.S. Geological Survey, Map Distribution \\ Box 25286, MS 306, Federal Center \\ Denver, CO 80225
}

\begin{abstract}
Any use of trade, product, or firm names in this publication is for descriptive purposes only and does not imply endorsement by the U.S. Government
\end{abstract}

\section{Library of Congress Cataloging-in-Publication Data}
Guidebook on the geology, history, and surface-water contamination and remediation in the area from Denver to Idaho Springs, Colorado / edited by K.C. Stewart and
R.C. Severson ; written contributions by Walter H. Ficklin ... [et al.] ; photographic contributions by John M. Epperson ... [et al.] ; graphics by Michael F. Duncan ... [et al.] ; editorial assistance by Thomas Kohnen.
p. cm.-(U.S. Geological Survey circular ; 1097)
Includes bibliographical references.
Supt. of Docs. no.: I 19.4/2:1097
1. Environmental gcology-Front Range (Colo. and Wyo.) 2. Environmental geology - Colorado-Denver Region. 3. Acid mine drainage-Front Range (Colo. and Wyo.) 4. Acid mine drainage-Colorado-Denver Region. I. Stewart,
Kathleen C. II. Severson, R.C. (Ronald Charles), 1945- . III. Series. QE92.F7G85 1994




\section{CONTENTS}

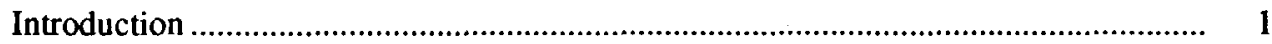

Tour Log-Denver to Idaho Springs and return, by Ralph R. Shroba,

Kathleen C. Stewart, and Wallace R. Hansen ............................................................ 3

Historical notes, by Kathleen C. Stewart .................................................................. 23

Geology and mineralization of the Idaho Springs and Central City Mining

Districts, by Helen W. Folger............................................................................. 33

Generation and interactions of mine drainage at the Argo Tunnel, by Kathleen S. Smith

Influence of acid-mine drainage on Clear Creek, Colorado, by Walter H. Ficklin and Kathleen S. Smith...

Constructed wetland treatment of acid mine discharge at Idaho Springs, Colorado, by John C. Emerick, Thomas R. Wildeman, Ronald R. Cohen, and Ronald W. Klusman

\section{ILLUSTRATIONS}

Figure 1. Map of guidebook route...

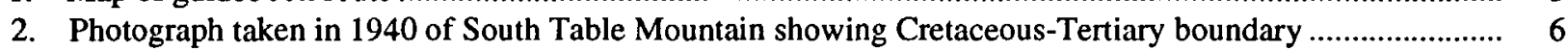

3. Stylized oblique areal view of the Colorado Front Range looking west from Denver toward Central City and Idaho Springs

4-7. Photographs showing:

4. Landslide with prominent tension fractures that disrupted a portion of the eastbound lanes of I-70 in 1984 ...

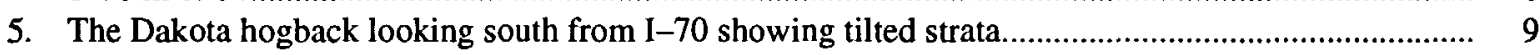

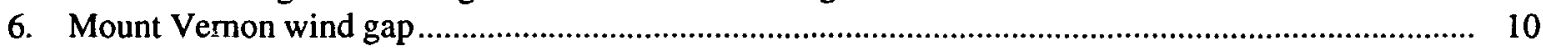

7. Roadcut exposing Precambrian gneiss and pegmatite in Mount Vernon Canyon................................ 12

8. Map showing the major northwest-trending faults that occur in the Front Range uplift between

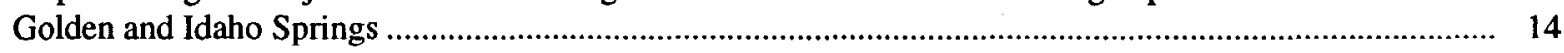

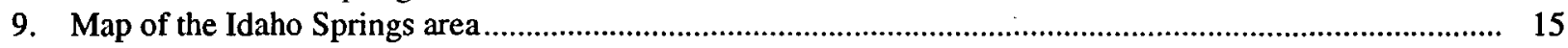

10-13. Photographs showing:

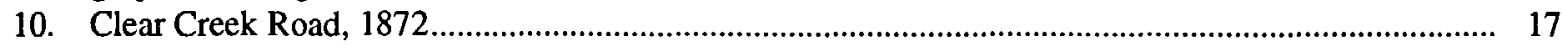

11. Narrow gauge railroad tracks at the junction of Clear Creek and North Clear Creek.......................... 18

12. Seven-ton rock that fell on U.S. Highway 6 in May 1991...................................................... 19

13. 'Beaver Creek railroad station and dance pavilion in the late 1800 's ......................................... 20

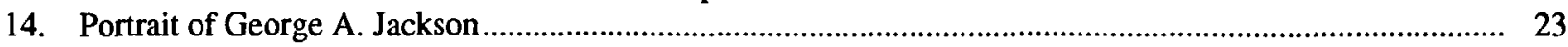

15. Map showing Argo and Big Five Tunnels in relation to Idaho Springs and Central City.

16-21. Photographs showing:

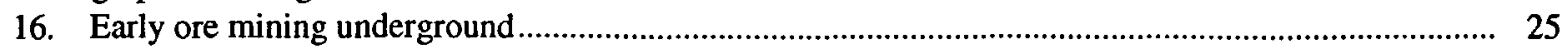

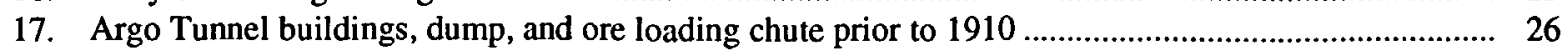

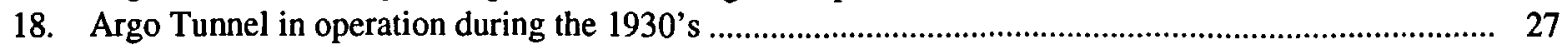

19. Ore cars of the Big Five Tunnel on their way to the mill .......................................................... 28

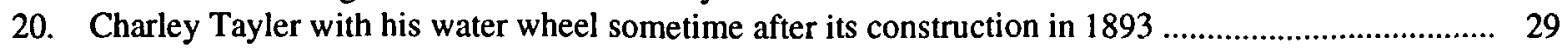

21. The Idaho Springs Natatorium in the early 1900's................................................................ 30

22. Map outlining the Front Range in Colorado and showing the location of the Central City and Idaho Springs Mining Districts in the Colorado Mineral Belt . 
23-25. Photographs showing:

23. Location of an ore vein marked by a hammer.

24. Unusual occurrence of a gold crystal resting on the edge of a galena crystal .....................................

25. Hydraulic dredge mining placer deposits along Clear Creek sometime after 1930 .............................. 36

26. Map outlining principal zones of ore mineralization according to Sims (1989) ......................................... 37

27. Diagrammatic representation of mine drainage reactions .................................................................... 40

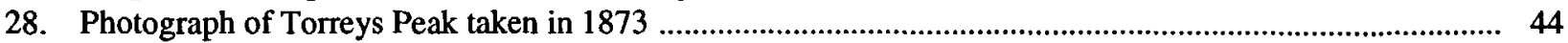

29. Map of location of sample collection sites along Clear Creek ................................................................ 44

30. Photograph of research chemist measuring $\mathrm{pH}$ with a portable meter ................................................. 45

31. Photograph of typical filter apparatus for water samples ................................................................... 45

32-35. Graphs showing:

32. Influence of various inflows on the dissolved and total concentrations of iron, manganese, copper, and zinc in water collected from Clear Creek in June 1986............................................................. 46

33. Influence of various inflows on the dissolved and total concentrations of iron, manganese, copper,

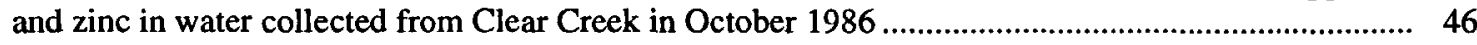

34. Proportion of suspended load of copper and zinc versus stream water $\mathrm{pH}$ downstream of the Argo Tunnel drainage into Clear Creek in June and October 1986

35. Distribution of loosely bound arsenic in Clear Creek sediment from near the Continental Divide to its mouth on the South Platte River.

36. Plan view and cross section of the Big Five Tunnel constructed wetland looking west .................. Photograph showing view toward the west of cattails growing in cells $\mathrm{A}, \mathrm{B}$, and $\mathrm{C}$ of the
37. Photo constructed wetland

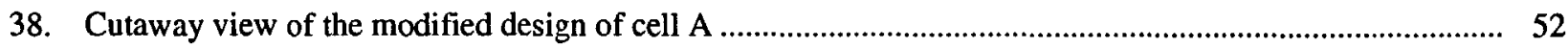

39. Cutaway view of the modified design of a cell B subcell ............................................................ 52

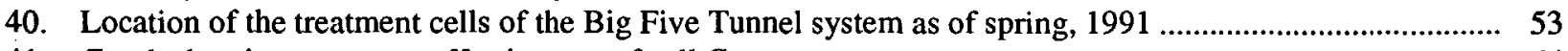

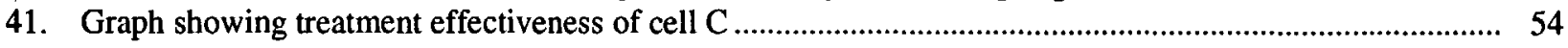

\section{TABLES}

1. Stratigraphic units in the Greater Denver area

2. Dissolved constituents in Argo Tunnel water, August 1985, and Clear Creek, October 1985 ................................. 47

3. Average concentrations and daily output for selected metals in the Big Five Tunnel effluent.................................. 50

4. Treatment effectiveness of all cells at the Big Five Tunnel constructed wetland site for selected metals .................... 53 


\section{Guidebook on the Geology, History, and Surface-Water Contamination and Remediation in the Area from Denver to Idaho Springs, Colorado}

\section{INTRODUCTION}

This guidebook for a 1-day drive in the Front Range west of Denver, Colorado, includes commentary on mountain landscapes, notes on the colorful mining history of the area, and discussions on the geology and some miningrelated environmental hazards in the Idaho Springs area. It was originally prepared as U.S. Geological Survey OpenFile Report $91-426$ for a field trip sponsored by Division A-5 (Environmental Quality) of the Soil Science Society of America on October 10, 1991. That original report has been revised and expanded to make this circular more useful as a self-contained guide. A pamphlet entitled "Mountains and Plains: Denver's Geologic Setting" is a complimentary general interest publication that is available free of charge from map sales in building 810 on the Denver Federal Center, Lakewood, Colorado. The pamphlet contains useful background information on the geologic setting of Denver and nearby portions of the Front Range.

A few precautions and suggestions are offered to make the trip safe and enjoyable. Idaho Springs is about 7,500 feet above sea level and the lower oxygen content of the air (about 50 percent that of sea level) may adversely affect people with heart or breathing problems. The wetlands are "wet" so use suitable footwear. The daily weather patterns are changeable. Mornings in Denver may be sunny and warm, but afternoons in Idaho Springs may be cloudy, windy, and cool with rain or snow; be prepared for all types of mountain weather.

As you travel westward from Denver into the mountains, successively older rocks are crossed. By studying the descriptions at the various mileage points and by taking time at each described STOP, you will get an excellent overview of the geologic events that shaped the Denver Basin and the mountains to the west. After traveling some 18 miles into the mountains, you will reach the old mining town of Idaho Springs. Here, you can learn about the two longest tunnels in the area-the Argo and Big Five Tunnels-and how the mine drainage affects the water of Clear Creek.

The Argo Tunnel near the east end of Idaho Springs drains part of the large Central City and Idaho Springs hardrock mining districts and is a source of acid water (which contains arsenic and other heavy metals) that drains into Clear Creek. At the west end of Idaho Springs is the Big Five Tunnel. Near the tunnel entrance an experimental constructed wetland demonstrates technology for the remediation of acid-mine drainage and removal of arsenic and heavy metals. Take an opportunity to view this experimental method for treatment of mine drainage. For access to the wetlands, prior arrangements must be made with the Department of Environmental Sciences and Engineering Ecology or Department of Chemistry and Geochemistry, Colorado School of Mines in Golden, Colorado. Otherwise, the wetlands may be viewed from the road. Permission to enter the Argo Tunnel property may be obtained from Jim Maxwell of Idaho Springs, who owns the hot springs resort. The tunnel may also be viewed from public roads.

After you leave Idaho Springs, the road log guides you down Clear Creek canyon, providing an opportunity to get a closer look at the various Precambrian rocks while traveling through one of Colorado's picturesque canyons. 


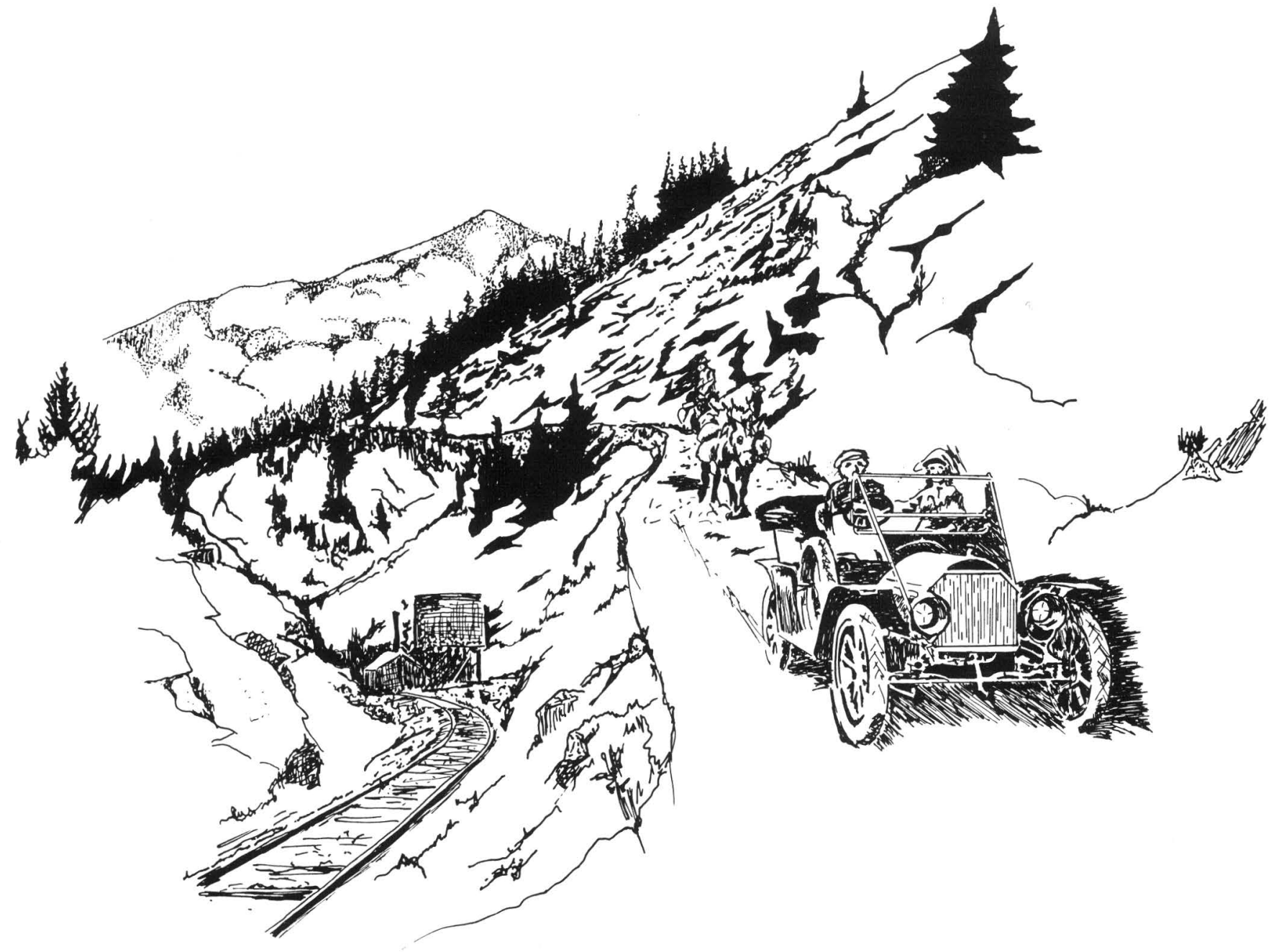




\title{
TOUR LOG-DENVER TO IDAHO SPRINGS AND RETURN
}

\author{
By Ralph R. Shroba, Kathleen C. Stewart, and Wallace R. Hansen
}

Begin at the Denver Metro Convention and Visitor's Bureau, corner of Colfax Avenue and Court Place (fig. 1). Denver stands on late Pleistocene terrace deposits composed of glacial outwash (Trimble and Machette, 1979). Building excavations in these deposits have sometimes uncovered mammoth bones and gold. Both Cherry Creek and the South Platte River (fig. 1) repeatedly flooded lower downtown Denver after it was founded in the late 1850's, but flood-control dams built about 100 years later have helped to reduce flooding. In this area Interstate 25 (I-25) is mostly on Holocene alluvium deposited by Cherry Creek and the South Platte River. The South Platte River has been extensively channelized by backfilling and restructuring to minimize flooding and improve land values. Consequently, the river no longer meanders freely across its floodplain here as it does northeast of Denver where it is not confined by flood control structures (Hansen and others, 1976).

Table 1 shows the stratigraphic units that are exposed in the Denver area and are mentioned in this log.

Proceed west on Colfax 3 blocks to Speer Boulevard (follow signs to I-25 north). Turn right and follow Speer Boulevard 1.2 miles and exit right onto I-25 northbound. Speer Boulevard parallels Cherry Creek. The overpass crosses railroad tracks, Holocene alluvium, and the Platte River.

Proceed 2 miles north on I-25. Take Exit 214B onto I-70 westbound. Proceed west on I-70.

At the present-day interchange of I-25 and I-70 stood the former Boston and Colorado Smelting Works. The smelter transferred operations from Black Hawk to Denver in 1879, where it processed ore from the Idaho Springs-Central City Mining Districts and other parts of the State (Hale, 1936).

The route of $\mathrm{I}-70$ is mostly on thin deposits of Holocene alluvium and eolian ${ }^{1}$ sand (Trimble and Machette, 1979).

${ }^{1}$ Windblown.

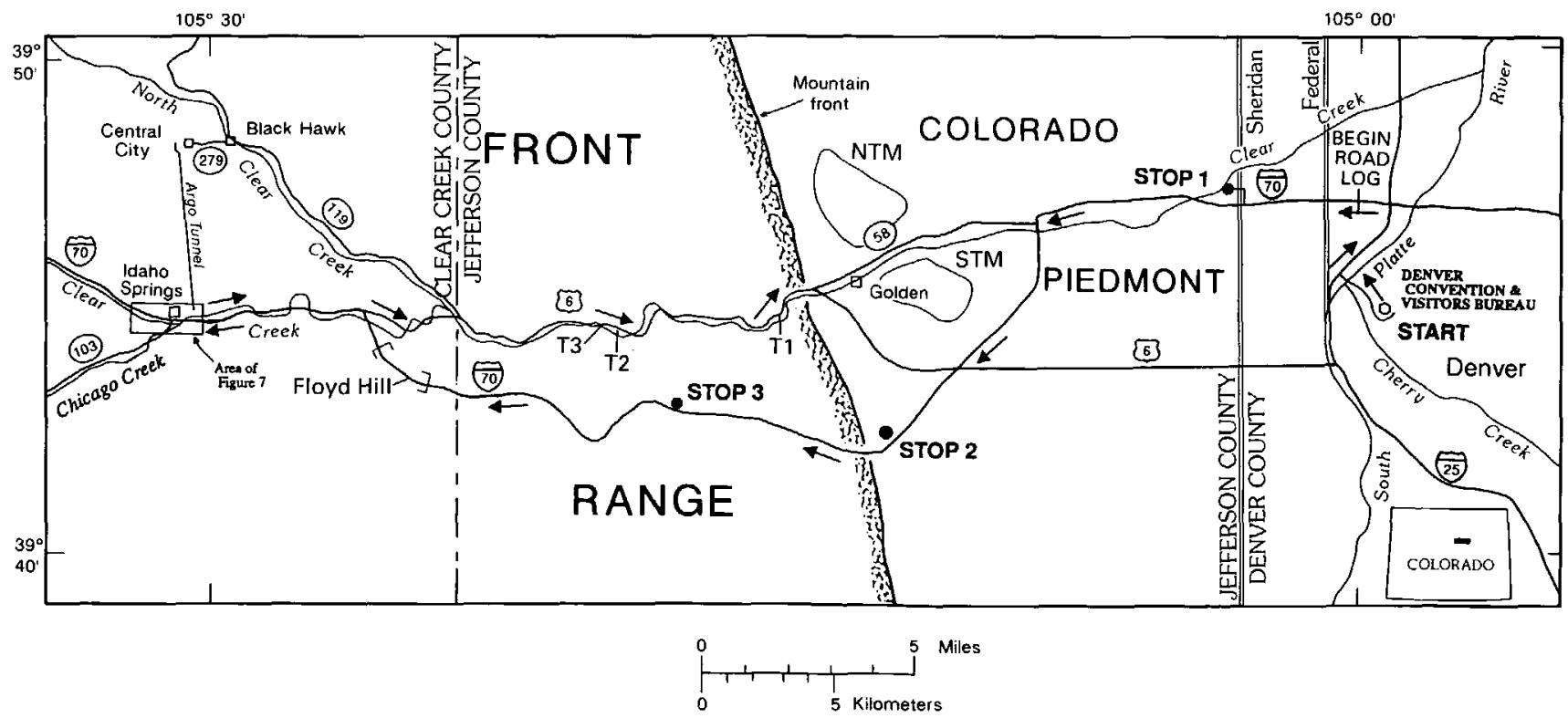

Figure 1. Map of guidebook route. Abbreviations: NTM, North Table Mountain; STM, South Table Mountain; T1, T2, T3, Tunnels 1,2 , and 3 . 
Table 1. Stratigraphic units in the Greater Denver area (modificd from Hansen and Crosby, 1982).

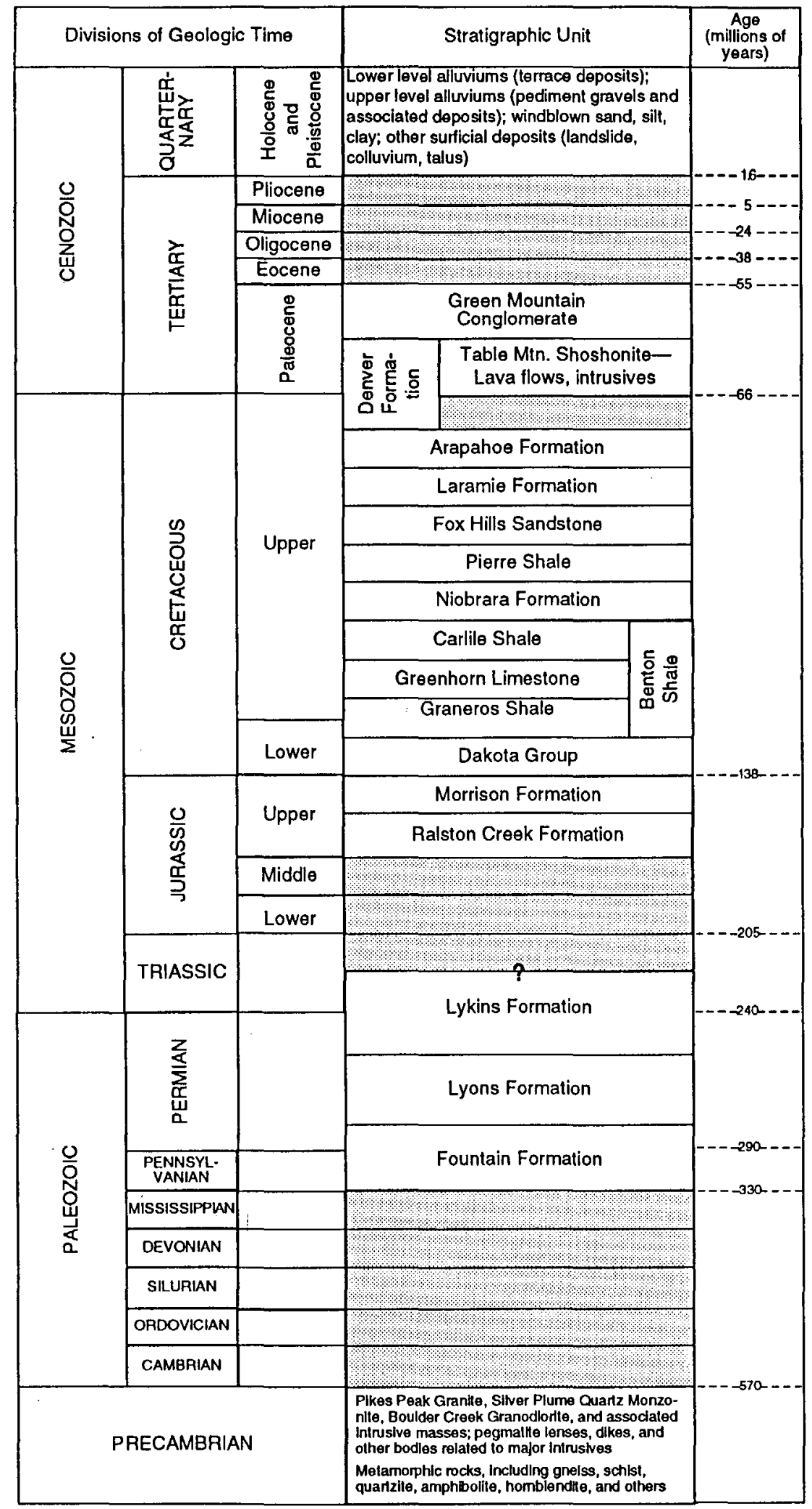




\section{Mileage}

0.0 Road log begins. Look for exit sign of Federal Boulevard attached to Pecos St. overpass. Just beyond the overpass, the highway route cuts into the underlying Denver Formation (table 1) (Hansen and others, 1976).

2.4 Exit I-70 at Exit 271A and Sheridan Boulevard. Turn right (north) at exit, proceed north on Sheridan Boulevard (Colorado Highway 95) for half a block and turn left (west) into Inspiration Point Park (at Ames Way and Benton Way). Follow left road (Ames Way) to parking area and walk west about $1 / 4$ mile to the overlook.

2.5 STOP 1. Inspiration Point Park overlook has outstanding views of Denver and the Front Range. Although now sheathed in concrete and asphalt, Inspiration Point is capped by a small remnant of middle Pleistocene alluvium that was deposited on a pediment ${ }^{2}$ surface eroded on the Denver Formation (Upper Cretaceous and Paleocene). The alluvium protected the underlying pediment surface as erosion proceeded to remove the surrounding, unprotected pediment; now this remnant alluvium is preserved well above modern stream levels. The valley of Clear Creek to the north and west of Inspiration Point contains late Pleistocene and Holocene alluvial gravel as much as 30 feet thick.

Much of the urban development visible from Inspiration Point postdates World War II. The valley of Clear Creek once contained extensive vegetable farms, but in the past 40 years they have largely been displaced by gravel pits, homes, and commercial establishments. A few farms are still visible from I-70. Some of the lakes produced by the gravel mining have been converted to recreational uses; other gravel pits have been backfilled with solid waste. Much of the gravel along Clear Creek still remains but is not likely to be mined because of urban growth (Hansen and others, 1976).

The flat tops of North and South Table Mountains to the west (fig. 1), near Golden, are capped by Paleocene lava flows (shoshonite). The shoshonite flows are interbedded with and, locally, overlie the Denver Formation. Above and far west of the Table Mountains are Mount Evans and the Continental Divide. Rolling topography in the middle distance cuts into a very broad but dissected late Eocene erosion surface (Scott and Taylor, 1986). Both Table Mountains and the late Eocene surface have a southward tilt, perhaps caused by middle Tertiary warping. On a clear day, Pikes Peak is visible 60 miles to the south and Longs Peak is visible 45 miles to the northwest (Hansen and others, 1976).

Follow path around to the right to historic marker. In 1850 Cherokee Indians en route to California and led by Louis Ralston discovered gold in Ralston Creek gravel near its confluence with Clear Creek. The discovery site is out of view north of the highway bridge that crosses the small visible portion of Clear Creek. Fur traders in the early 1800's referred to Clear Creek as "Vasquez" Fork after trader Louis Vasquez. Vasquez built a fur-trading fort in 1835 on the South Platte River about 40 miles northeast of Denver (Hafen, 1964).

3.1 Leave Inspiration Point Park, turn right (south) onto Sheridan Boulevard, go one block to $W$. 48th Avenue, turn right (west), and follow signs for I-70 west along W. 48th Avenue to Harlan Street.

\footnotetext{
${ }^{2}$ Broad, gently sloping erosion surface formed on bedrock near the base of a mountain front.
} 
3.8 Re-enter westbound I-70 at the intersection of Harlan Street and W. 48th Avenue. For about the next 5.5 miles the route traverses mostly late Pleistocene and Holocene alluvium of Clear Creek (Trimble and Machette, 1979).

\subsection{Cross Clear Creek.}

4.9 Cross over Wadsworth Boulevard. On the left (south), middle Pleistocene alluvium overlies bluffs formed in the Denver Formation (Hansen and others, 1976).

\subsection{Cross Clear Creek.}

8.6 North and South Table Mountains and a large gravel pit on the right. Since World War II, gold haś been recovered as a byproduct of these gravelmining operations (Van Horn, 1976).

10.6 South Table Mountain on the right. Near the southeast corner of South Table Mountain, the Cretaceous-Tertiary boundary (table 1) is exposed below a sequence of gray beds in the Denver Formation, about 150 feet below the base of the lava flow (fig. 2) (Brown, 1943; Van Horn, 1976). Brown found remains of Paleocene flora above the boundary and fragments of dinosaur bones below it. The boundary thus marks the end of the age of dinosaurs in this area.

12.7 Cross U.S. Highway 6. On the left, Green Mountain is capped by Green Mountain Conglomerate (Paleocene).
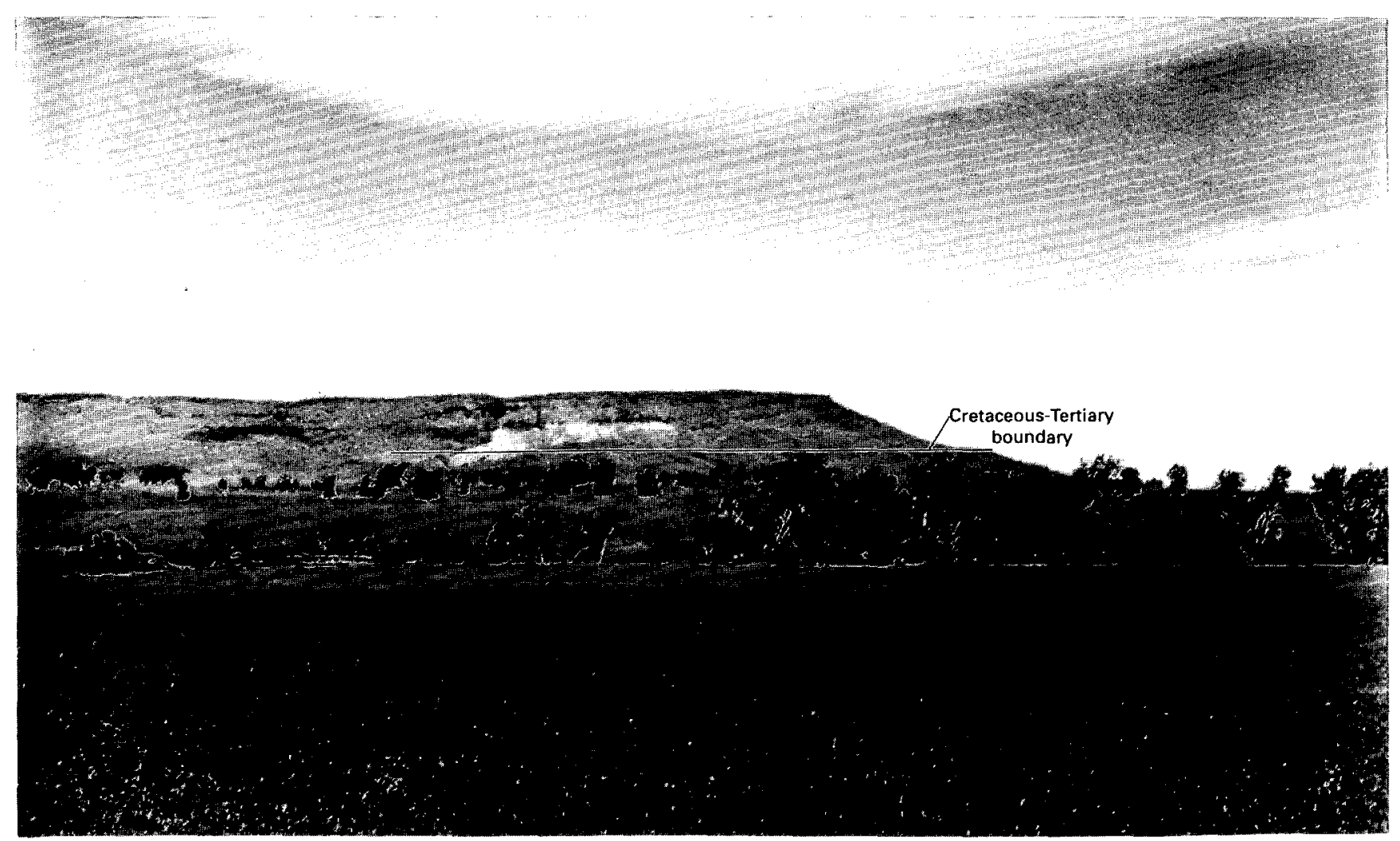

Figure 2. Photograph taken in 1940 of South Table Mountain showing Cretaceous-Tertiary boundary (U.S. Geological Survey photograph by R.W. Brown, in Brown, 1943). Vicw is to the north of southeast side of the mountain. 
13.6 Two-lane exit for $\mathrm{C}-470$. Note clay pit scars along the prominent ridge (Dakota hogback) to the west and some remnants of clay mining in the valley between Green Mountain and the ridge.

14.3 The Golden Fault dips beneath the mountain front. It is one of the major faults involved in uplift of the Front Range (fig. 3).

\subsection{Stay in right lane to take Morrison Exit 259.}

14.5 Approximate location of 1984 landslide that disrupted a short portion of the eastbound lanes of I-70 (fig. 4).

14.7 Take Morrison Exit 259 to Colorado Highway 26. Turn right at traffic light and park in lot north of I-70.

STOP 2. The roadcut through the hogback exposes a sequence of east-dipping sedimentary rocks of the Dakota Group, Morrison Formation, and Ralston Creek Formation (fig. 5; table 1) (Trimble and Machette, 1979). Steep dips in these rocks

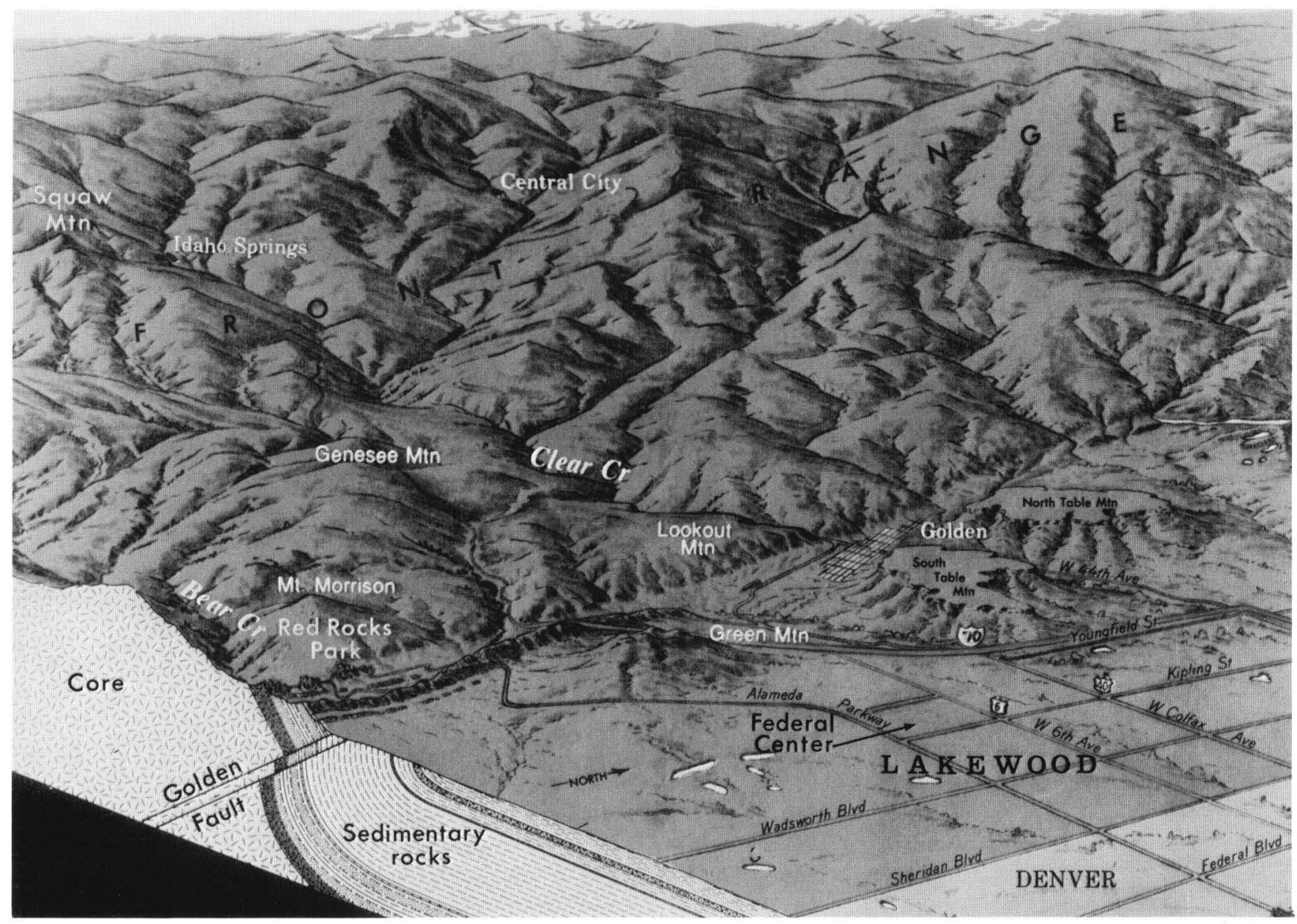

Figure 3. Stylized oblique areal view of the Colorado Front Range looking west from Denver toward Central City and Idaho Springs. Cross section in lower left-hand corner shows approximate location of the Golden Fault. Major faulting during Laramide time uplifted the crystalline rocks of the Precambrian core and subsequent erosion left only remnants of the overlying Paleozoic and Mesozoic sedimentary rocks along its eastern flank. Travel route of I-70 can be seen. 


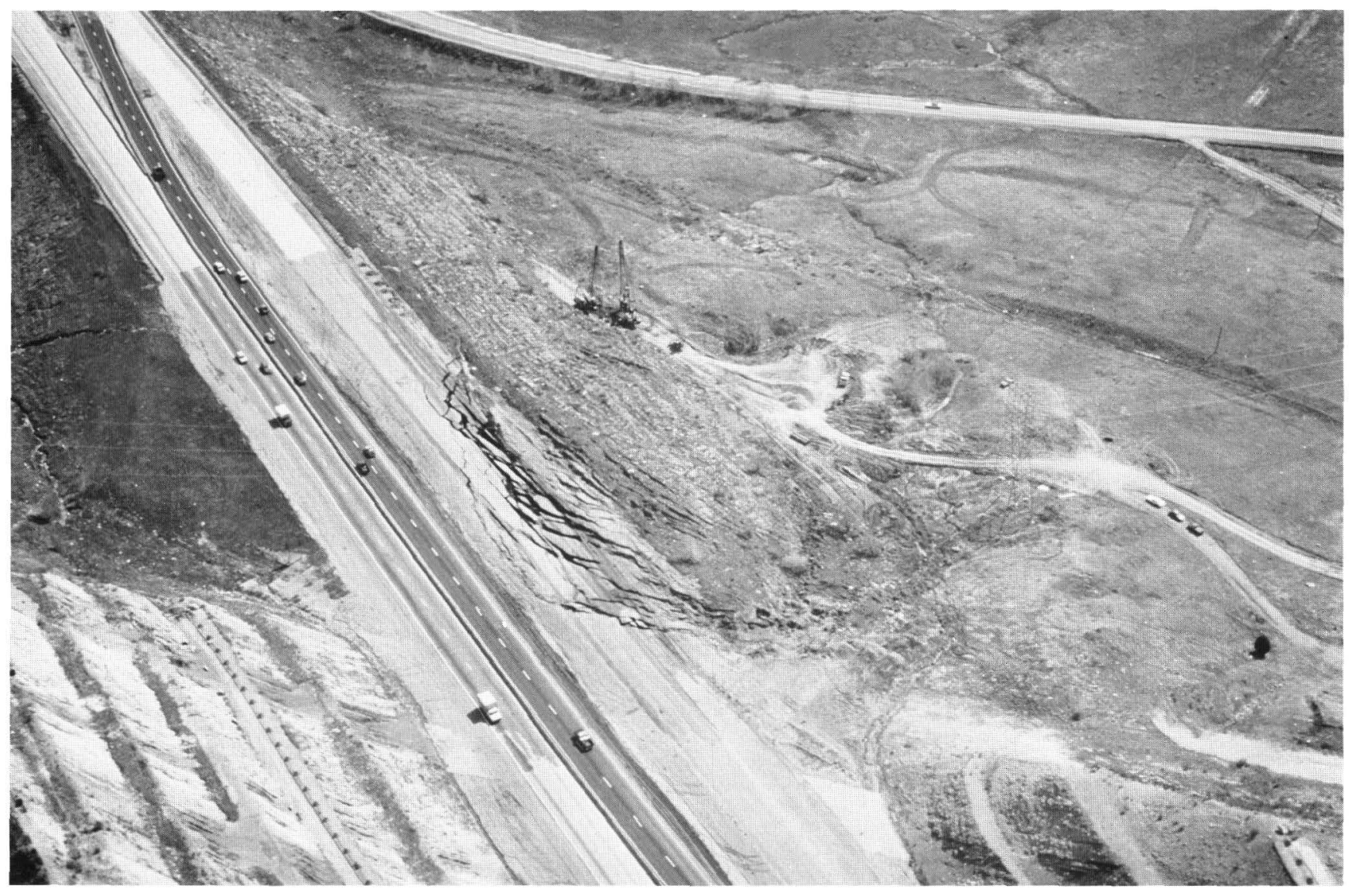

Figure 4. Landslide with prominent tension fractures that disrupted a portion of the eastbound lanes of $I-70$ in 1984 . Colorado Department of Transportation photograph (printed with permission).

are caused by sharp folding along the east flank of the Front Range uplift and resulting drag along the Golden Fault (fig. 3). Rocks on both sides are sharply flexed, even overturned. The major faulting occurred during Laramide time $^{3}$ but seismic instruments in Golden detect mild on-going activity (Kirkham and Rogers, 1978). The rocks with descriptive markers can be viewed in detail from the foot path that starts at the parking area.

Green Mountain is visible to the east. Below the conglomerate cap, unstable colluvial $^{4}$ slopes and expansive soils derived from the Denver Formation have posed problems for housing developments on Green Mountain (Robinson and others, 1976). Expansive soils are widespread in those parts of the Denver area that are underlain by the Pierre Shale and the Denver Formation (table 1). They contain clay that swells or expands when the mineral lattice absorbs water. This swelling may cause severe damage to light structures, such as houses and highways, unless adequate precautions are taken during construction. Builders and engineers commonly call the clay "bentonite," but to soil scientists it is "smectite." The landslide in figure 4 resulted from failure of roadfill placed on expansive shale and mine tailings (Larry McKenzie, Colorado Department of Transportation, oral commun., 1991).

\footnotetext{
${ }^{3}$ Late Cretaceous to Eocene time (Tweto, 1975).

${ }^{4}$ Composed of loose rock or unconsolidated material deposited by rainwash or gravity at the base of gentle slopes or hillsides.
} 


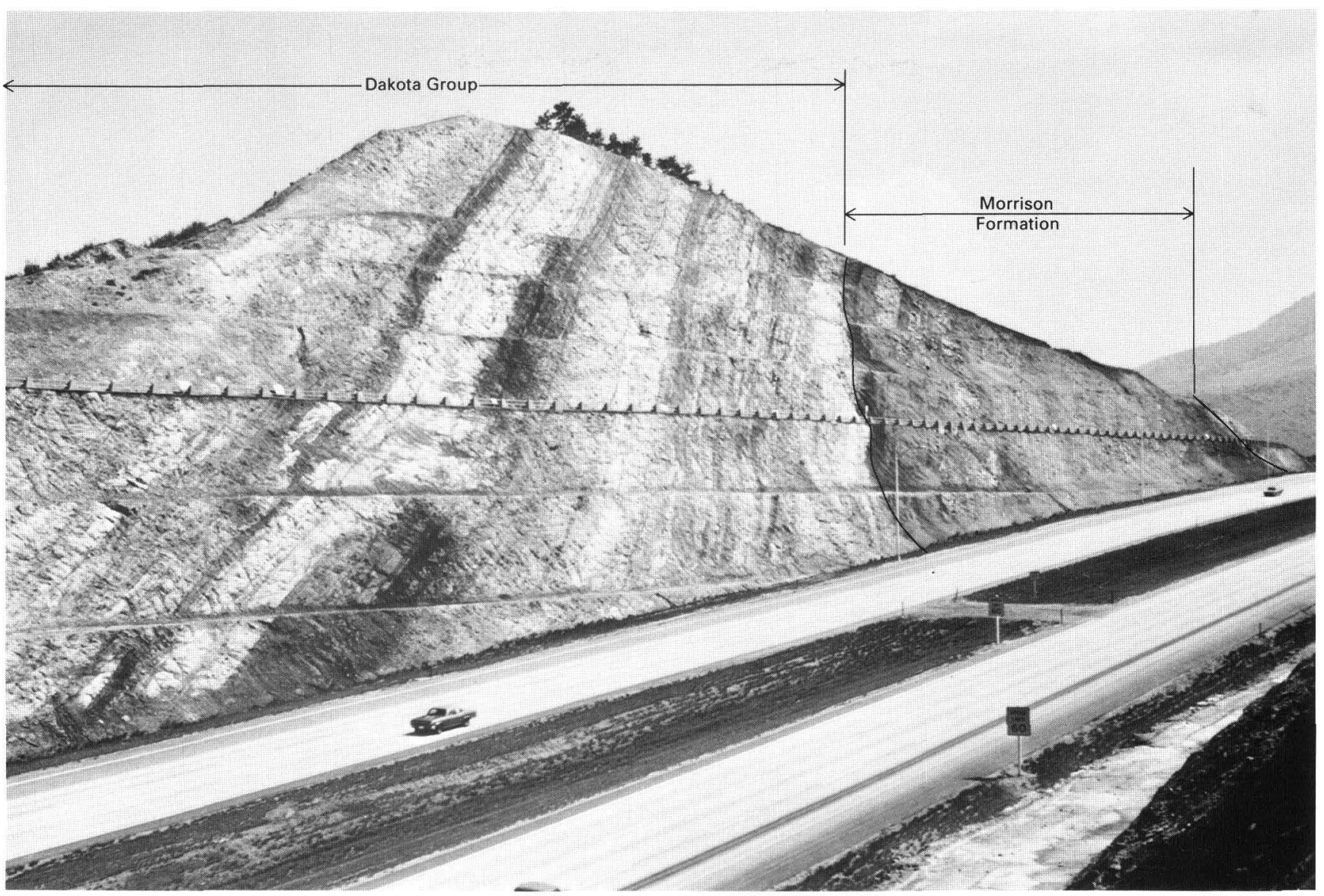

Figure 5. The Dakota hogback looking south from I-70 showing tilted strata. Lines demark the Dakota Group and the Morrison Formation (U.S. Geological Survey photograph by W.R. Hansen, July, 1972; Hansen and Crosby, 1982).

The clay pits that were visible from I-70 in the Dakota Group are near the top of the hogback. Non-expansive clays have been mined along the foothills of the Front Range for over 100 years. These non-expansive clays are suitable to make brick, tile, sewer pipe, and pottery. Clays were obtained chiefly from the Laramie Formation, but also from the Arapahoe Formation, Dakota Group, and Benton and Pierre Shales (table 1). Pits in the Dakota Group previously supplied refractory (ceramic) clays, but industrial ceramics manufactured in the Golden area today (figs. 1 and 3) use clay blends mostly from out of state (Waag, 1952; Hansen and Crosby, 1982).

From the west end of the roadcut to the entrance of Mount Vernon Canyon, I-70 crosses Jurassic to Pennsylvanian sedimentary rocks-the oldest exposed sedimentary rocks in the Denver area (Reed and others, 1987). Dinosaur bones are abundant in Mesozoic rocks in the Denver area. They were first discovered in 1877 in the Morrison Formation (Upper Jurassic) about 2 miles south of here (Lockley, 1988). The Morrison Formation is visible on the west end of the roadcut (fig. 5).

The steeply tilted red rocks south of I-70 and west of the hogback are resistant conglomeratic sandstones of the Fountain Formation (Pennsylvanian and Lower Permian). These sandstones are well exposed in Red Rocks Park about 2 miles to the south (fig. 3). Between this formation and the underlying Precambrian rocks there is a gap in geologic time of about 240 million years (table 1). 
Colorado Highway 26, which passes under I-70, was the route of the Denver, Auraria, and Colorado Wagon Road. Entrepreneurs built this freight road up Mount Vernon Canyon in 1859 to transport supplies for miners in Central City (Scott, 1976).

About a half mile to the southeast (not visible from here) is a large notch in the hogback. This notch is the Mount Vernon wind gap (fig. 6). The gap will be visible to the east (to the left) just after you re-enter I-70.

As the Rocky Mountains rose over the last 67 million years, many creeks and rivers gradually cut through Paleozoic and Mesozoic rocks into the underlying Precambrian rocks, following ancient eastward-flowing stream courses. During the Eocene (38-55 million years ago; table 1), the uplift slowed or stopped. As a result, a broad, sloping plain or pediment developed on what was then mountains of low relief- - a late Eocene erosion surface. Starting about 28 million years ago (Oligocene) the rate of uplift increased (Scott and Taylor, 1986). From the Miocene through Pliocene (24-1.6 million years), the Rockies continued to rise. Between 1 and 2 million years ago, the creek of MountVernon Canyon still flowed across the hogback through the wind gap. To the south, however, Bear Creek, with its larger drainage basin, was downcutting at a much faster rate. One of the minor tributaries of Bear Creek relatively quickly cut its way northward through the siltstones and claystones of the Morrison, Ralston Creek, and Lykins Formations until it reached Mount Vernon Creek. Mount Vernon Creek was then diverted. As

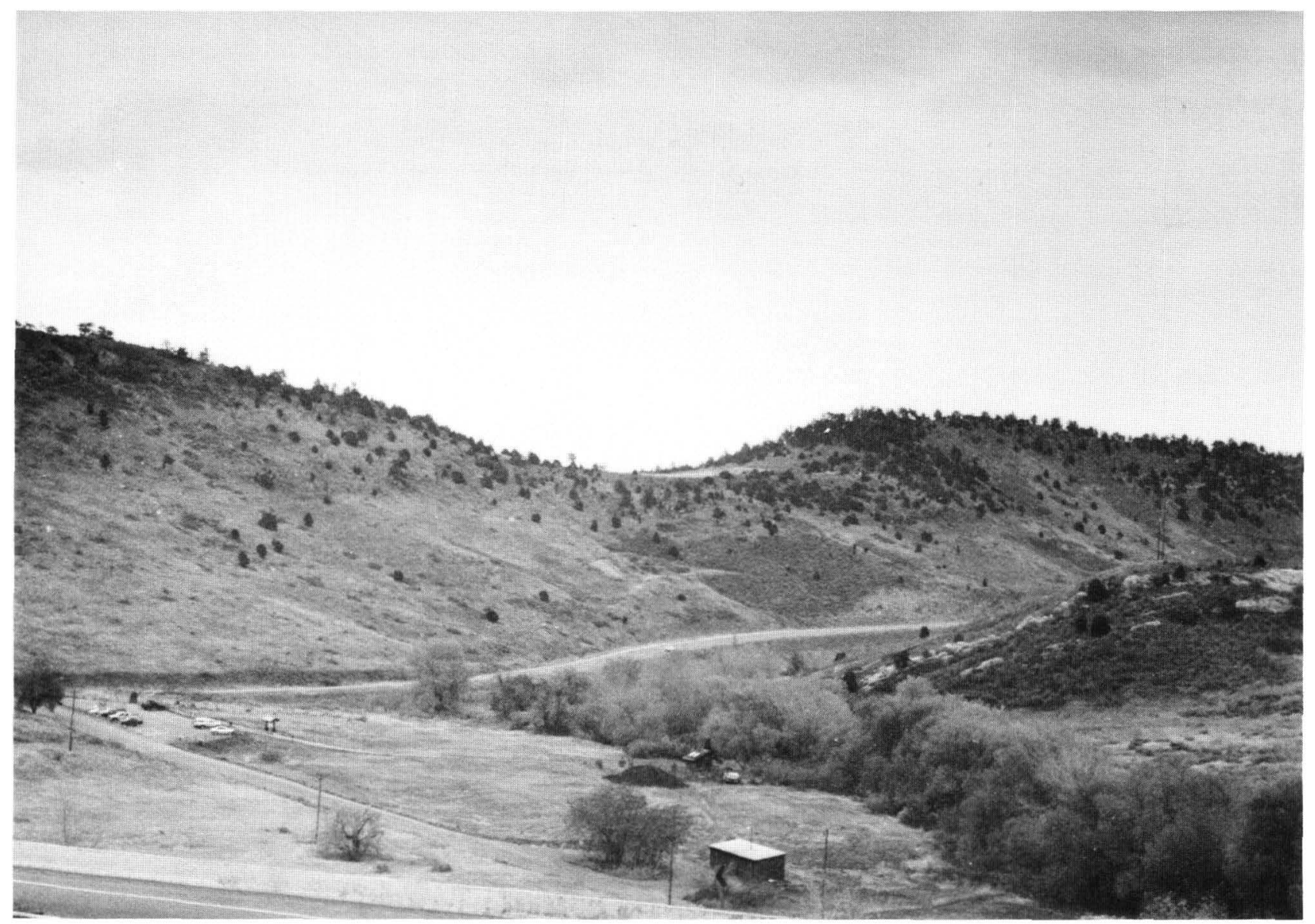

Figure 6. View to the southeast of the Mount Vernon wind gap. Mount Vernon Creek flowed eastward cutting through the hogback until a quickly downcutting tributary of Bear Creek diverted the streamflow southward (photograph by Thomas Kohnen). 
downcutting continued in response to further uplift, the notch you see today was left (fig. 6). This action of one stream capturing the waters of another is called stream piracy (Scott, 1972).

\section{Exit parking lot, turn left onto Highway 26 and right at traffic light.}

\subsection{Re-enter I-70 westbound.}

15.5 Look back to the left to see the Mount Vernon wind gap.

15.6 Highway enters the mouth of Mount Vernon Canyon. Rocks exposed along the route between the canyon mouth and Idaho Springs are mostly felsic ${ }^{5}$ gneiss, biotite gneiss, hornblende gneiss ${ }^{6}$, and amphibolite ${ }^{7}$ of Precambrian age (Bryant and others, 1981). At the mountain front these Precambrian rocks are oxidized to great depths, perhaps from extensive weathering before the overlying Pennsylvanian rocks were deposited, but farther up the canyon, near-vertical roadcuts expose fresh, unweathered rock.

17.2 Roadcut exposing unweathered Precambrian rock and pegmatite ${ }^{8}$ dikes (fig. 7). Notice vertical drill-hole scars made during highway construction.

Low terraces visible along Mount Vernon Creek and its tributaries were entrenched by flood waters after intense thunderstorms dropped 8.5 inches of rain in 3 hours at the head of Mount Vernon Canyon on September 2, 1938 (Follansbee and Sawyer, 1948; Hansen and others, 1978).

20.4 The head of Mount Vernon Canyon is near Exit 254.

20.5 Exit $1-70$ just west of Exit 254 at the Buffalo Herd Overlook and park.

STOP 3. Panoramic View. In 1912, the City of Denver acquired land on both sides of the highway here for additions to the Denver Mountain Parks System. Bison were imported in 1913 from Yellowstone National Park and their descendants still graze here in addition to elk and deer.

Victory Pass on the old wagon road lies just to the east. The Patrick House, a former stage stop built in 1860 , stands in the trees on the hill to the southwest, and the old wagon road parallels I-70 in the trees. A barn to shelter horses after the ascent of Mt. Vernon Canyon once stood where the windmill is today (Marty Homola, Denver Mountain Parks, oral commun., 1991).

To the west is a view of the late Eocene erosion surface (Scott and Taylor, 1986) and the high peaks along the Continental Divide. For the next 7 miles, I-70 crosses rolling topography of the dissected late Eocene erosion surface. Remnants of the surface north of Clear Creek Canyon are locally visible from several points along I-70. Most of the bedrock here is deeply weathered, making it easy to excavate for mountain homesites, roads, and utility corridors (Schmidt and Pierce, 1976). Ridges capped by Pliocene or Miocene gravels that were deposited in the ancestral channel of Clear Creek are

\footnotetext{
${ }^{5}$ A light-colored igneous rock composed mostly of light-colored feldspars and silica (quartz).

${ }^{6}$ Banded metamorphic rock formed by high temperature and pressure. Mineral names, such as biotite and homblende, are used to describe major components or a distinctive composition of a gneiss.

${ }^{7}$ Amphibole-rich rock.

${ }^{8}$ Very coarse grained igneous rocks that forms veins and dikes in older igneous rocks.
} 


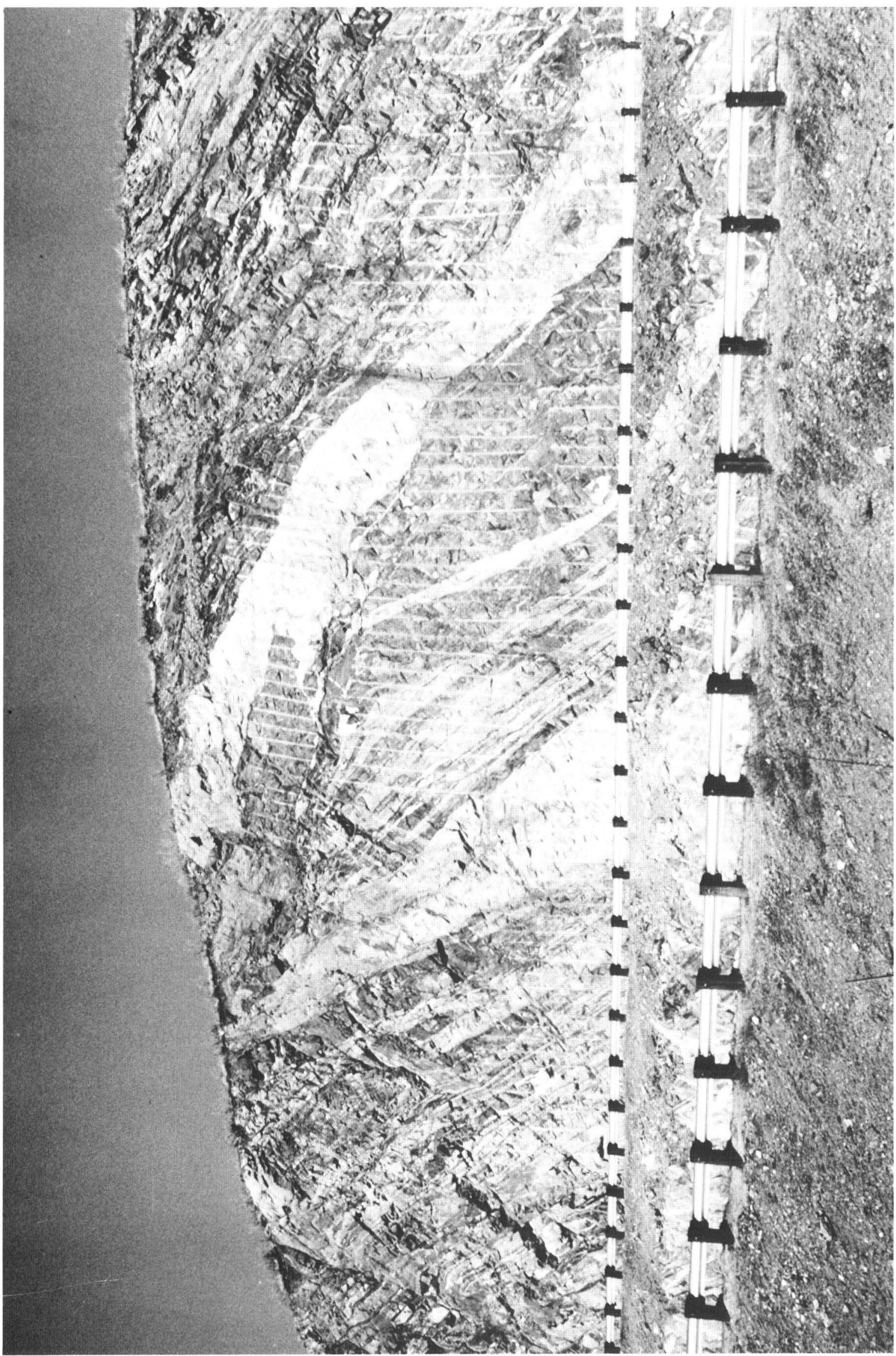

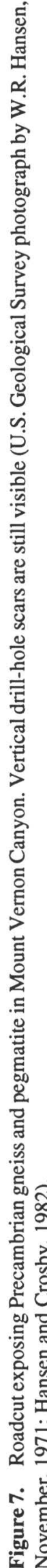


occasionally visible. The ancient channel is several hundred feet below the late Eocene erosion surface and 400 to 600 feet above the present stream. Remnants of the gravel extend discontinuously eastward almost to the mouth of the canyon, where they lie several hundred feet above the projection of the highest Pleistocene pediment surfaces in the Colorado Piedmont (fig. 1) (Reed and others, 1987). Roadcuts in the bedrock expose interlayered felsic gneiss, amphibolite, and hornblende gneiss cut by dikes of pink granite ${ }^{9}$ and pegmatite (Reed and others, 1987).

\section{Proceed west and re-enter westbound I-70.}

21.3 View to the right, just before the Chief Hosa Exit (Exit 253), of Pliocene or Miocene gravel in the ancestral channel of Clear Creek, below the late Eocene erosion surface, forms the large east-west trending ridge.

26.2 Cross county line into Clear Creek County, just beyond Exit 248.

Large subdivision on the left. Residential developments in the foothills of the Front Range commonly experience problems obtaining adequate water for drinking and waste disposal (Hansen and Crosby, 1982).

27.5 Overpass, Floyd Hill summit is just ahead. The northwest-trending Floyd Hill fault occupies the saddle at the summit (fig. 8). It is one of many northwesttrending faults in Colorado that have had recurrent movement since Precambrian time (Tweto, 1979; Kirkham and Rogers, 1978; Hansen and Crosby, 1982).

27.8 Descend Floyd Hill into Clear Creek Canyon. Across the canyon, the ridge north of Clear Creek is capped by Pliocene or Miocene gravel. Roadcuts below the summit of Floyd Hill expose the same interlayered gneiss, amphibolite, pink granite dikes and pegmatite mentioned previously (Reed and others, 1987).

29.6 Large rockslide on the south side (left) of Clear Creek just above the junction of I-70 and U.S. Highway 6 . It is moving along foliation ${ }^{10}$ in the biotite gneiss bedrock (Robinson and others, 1976).

29.8 Across Clear Creek, large roadcuts on the right expose migmatitic ${ }^{11}$ biotite gneiss and schist, ${ }^{12}$ which contain pods ${ }^{13}$ and deformed layers of pegmatite (Reed and others, 1987).

32.0 East portal of the highway tunnel. Well-exposed felsic gneiss and amphibolites crop out to the right of the tunnel (Reed and others, 1987).

32.5 Roadcut exposes late Pleistocene glacial outwash gravel.

33.0 Exit 1-70 at Exit 241A toward Idaho Springs. Follow Business 70 about 1 mile west to a small municipal park on the south side of Clear Creek across from the Argo Mill (fig. 9).-[Refer to the section by Stewart in this report entitled "Historical Notes" for information on the Idaho Springs area. (p. 23)]

\footnotetext{
${ }^{9} \mathrm{~A}$ light-colored, coarse-grained intrusive rock consisting primarily of quartz and feldspar.

${ }^{10}$ Planes formed by the flattening and alignment of minerals in metamorphic rock.

"Composite of igncous and metamorphic rock whose crystallinc struclure can be dislinguished with the unaided cye or a hand lens.

${ }^{12}$ Layered crystalline rock formed by low-grade metamorphism.

${ }^{13}$ Elongate bodies enclosed in schist and parallel to the lines of deformation.
} 


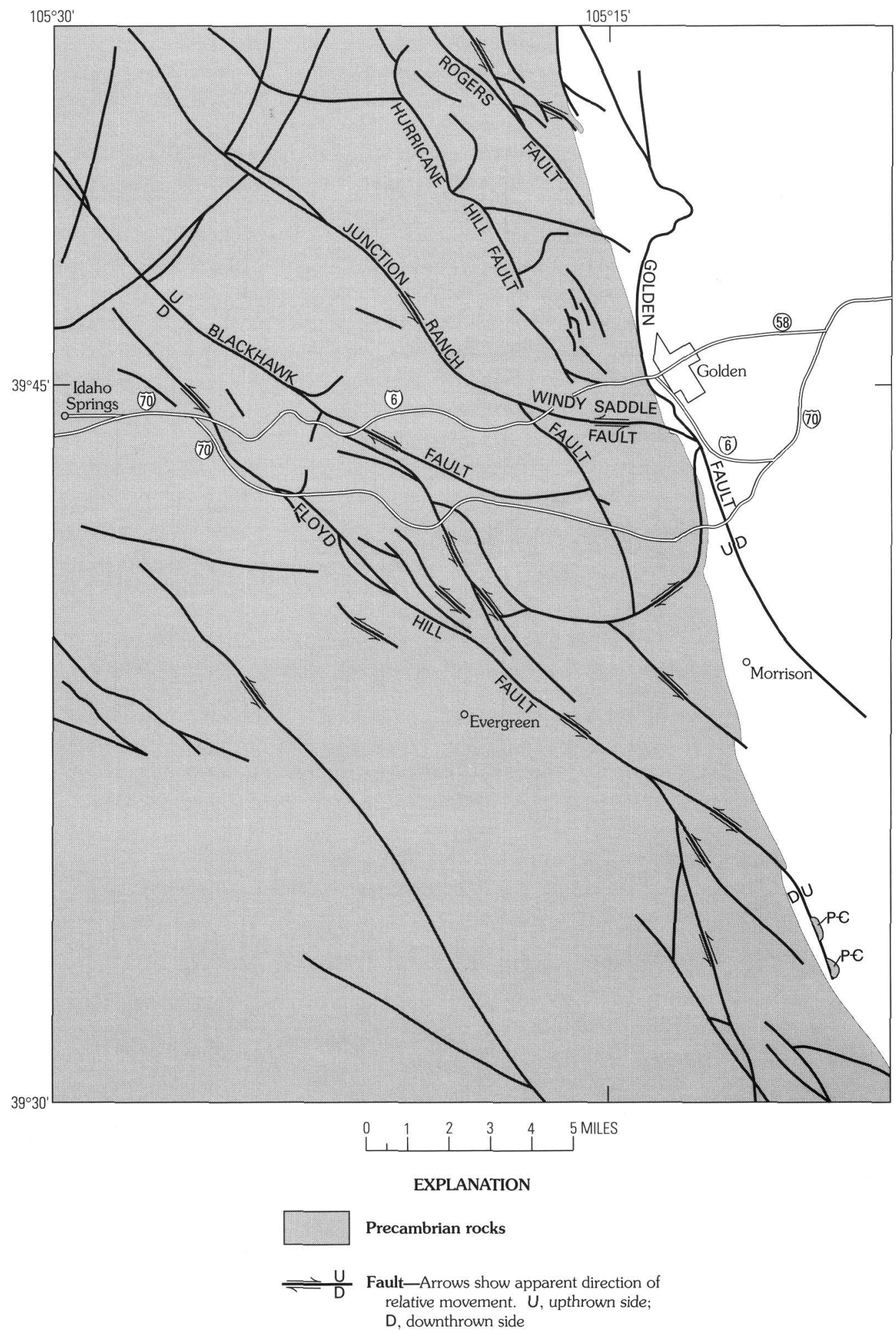

Figure 8. Map showing the major northwest-trending faults that occur in the Front Range uplift between Golden and Idaho Springs (adapted from Sheridan and others, 1972). 
33.9 STOP 4A. Argo Tunnel. - - [Refer to the sections in this report on the economic geology of the area by Folger (p. 33), chemistry of acid mine drainage by Smith (p. 39), and the tunnel effluent by Ficklin and Smith (p. 43).] The tunnel drainage may be viewed by walking across the bridge and along the road toward the mill.

Leave municipal park and proceed west on Business 70. Virginia Canyon can be seen to the right [See section by Stewart entitled "Historical Notes" that discusses Idaho Springs (p. 23).]

34.2 Cross Clear Creek. - Much of downtown Idaho Springs is built on late Pleistocene outwash gravel. The lower limit of Pleistocene glaciation in the valley of Clear Creek is marked by subdued moraines near Lawson about 6 miles west of Idaho Springs (Bryant and others, 1981).

35.2 Turn left (south) onto 1st Avenue. Park on right (west) side of the street.

STOP 4B. - If arrangements have not been made to view the wetlands with Colorado School of Mines personnel, walk back to Business 70, turn left, and walk toward the I-70 overpass to observe the constructed wetlands and the portal of the Big Five Tunnel on the left within the fenced enclosure. [Refer to the sections in this report by Emerick and others entitled "Constructed wetland treatment of acid mine discharge at Idaho Springs." (p. 49) and by Stewart entitled "Historical Notes, Big Five Tunnel” (p. 26).]

Leave the wetland. Turn left (east) onto Miner Street and left (north) onto 2nd Avenue. Proceed north on 2nd Avenue to Business 70.

\subsection{Turn right (east) onto Business 70 (Colorado Boulevard) and proceed east.}

36.0 Turn right (south) onto 13th Avenue and proceed south.

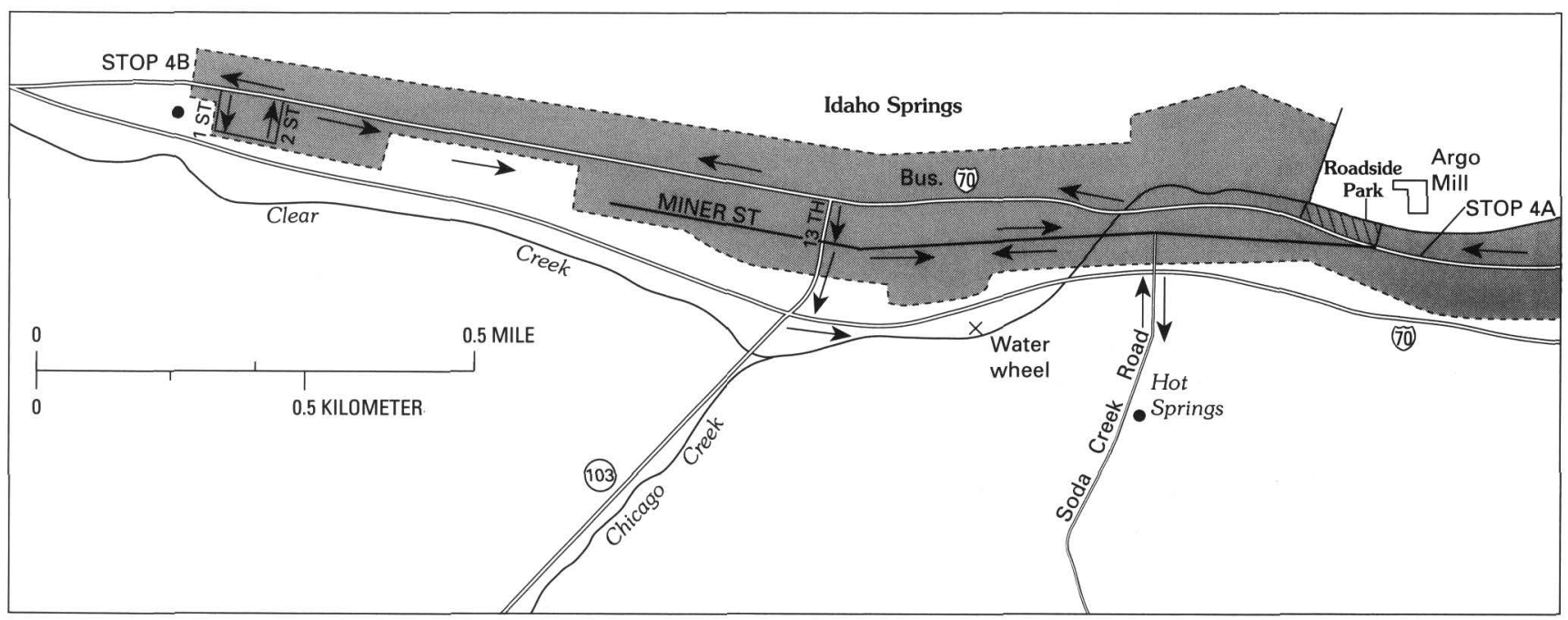

Figure 9. Map of the Idaho Springs area. 
36.1 Turn left (east) onto Miner Street and proceed east on Miner Street. (You can turn right onto 17th Avenue and park. Follow the footpath under I-70 to see the Charley Tayler Water Wheel. [Refer to the section in this report by Stewart entitled "Historical Notes, Charley Tayler Water Wheel" (p. 28).] Remember to adjust your mileage for this stop.)

36.4 Cross Clear Creek.

36.5 Turn right (south) orto Soda Creek Road. Proceed south on Soda Creek Road.

36.7 Hot springs resort. - [Refer to the section in this report by Stewart entitled "Historical Notes" concerning "Hot Springs." (p. 29)]

Retrace route to the intersection of Soda Creek Road and Miner Street.

37.0 Turn left (west) onto Miner Street and proceed west.

37.3 Intersection of Miner Street and 14th Avenue. - Note the stone mill (arrastre) on the left in front of the library on the northwest corner of Miner Street and 14th Avenue. (Depicted on p. 32.) This Spanish-style mill was used to grind gold ore in the Idaho Springs area (Cox, 1989).

37.4 Intersection of Miner Street and 13th Avenue. Turn left (south) onto 13th Avenue (Colorado State Highway 103), cross bridge, and turn left to enter eastbound I-70. - Straight ahead (south) is the valley of Chicago Creek where George Jackson made his gold discovery in 1859.

37.7 Waterwheel on the right. - To the left (north), across the valley, Virginia Canyon can be seen.

42.0 Exit I-70 left at Exit 244 and follow U.S. Highway 6 down Clear Creek Canyon.

42.4 Rock quarry on the left. - As gravel resources along Clear Creek in and near Denver have been depleted or converted to other use, entrepreneurs have been able to develop quarries like this one for crushed rock.

42.6 Just east of the junction of I-70 and U.S. Highway 6 , the road passes from migmatitic biotite schist and gneiss through a sequence of interlayered calc-silicate ${ }^{14}$ gneiss, hornblende gneiss, and amphibolite, and into a large body of amphibolite.

43.3 Bed of the narrow-gauge Colorado Central Railroad on the opposite side of Clear Creek. The bed is frequently visible throughout the canyon (Reed and others, 1987). The Colorado Central Railroad built this route to Black Hawk along the former route of the Clear Creek Road in 1872 (fig. 10) (Scott, 1976; Hauck, 1972). The Colorado and Southern Railroad bought the route in 1899 and abandoned it in 1941 (Morgan, 1974).

43.4 Cinder block building on the south side of Clear Creek is the site of a former radium baths resort. dolomite. 


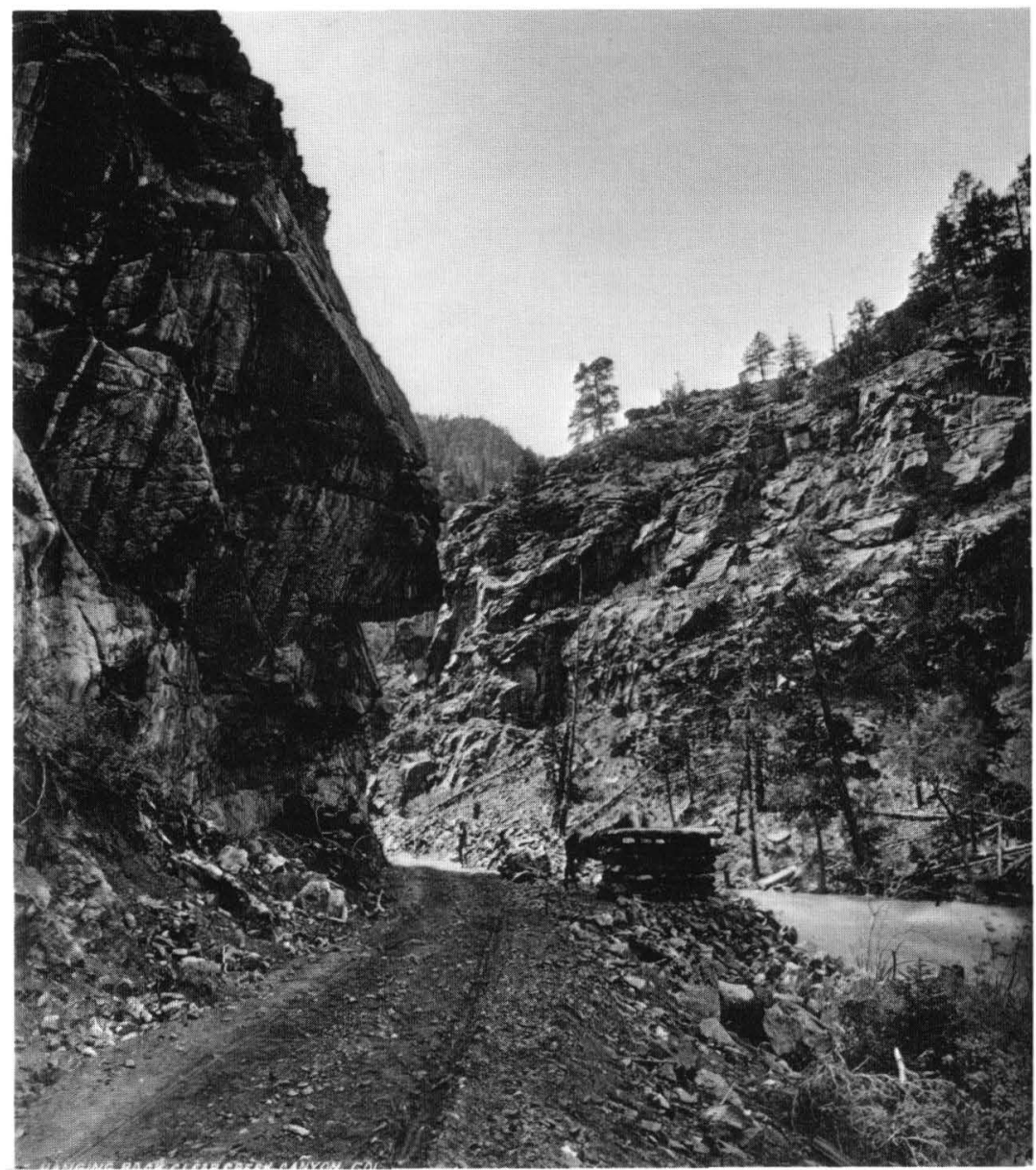

Figure 10. Clear Creek Road, 1872. Ties to be laid for railroad are at edge of the embankment (U.S. Geological Survey photograph by W.H. Jackson).

45.0 Intersection with Colorado Highway 119. - - Highway 119 heads northwest to Black Hawk. Area along this curve to the right is a landslide that has been slipping down the bedrock intermittently and crowding the road for many years.

45.1 Cross county line into Jefferson County. - Confluence of North Clear Creek with Clear Creek. The Colorado Central Railroad built a water tower and station at this location (fig. 11). Tracks from mining areas on both forks of Clear Creek joined here and continued eastward to Golden (Hauck, 1972). Just downstream from the road intersection is one of four sites proposed for dams on Clear Creek (Colorado Water Resources and Power Development Authority, oral commun., 1991). Continue east on U.S. Highway 6.

To the left, along Highway 119, can be seen interlayered amphibolite and biotite-quartz-plagioclase ${ }^{15}$ gneiss cut by a prominent light tan pegmatite just above the road (about 6 to 10 feet) (Hutchinson and others, 1976).

45.7 Dredge tailings are conspicuous here and there for the next 2 miles downstream. Steep canyon walls give way in places to broader, gentler slopes along fault zones that are more easily weathered and eroded than the adjacent bedrock. The dominant bedrock in the canyon is quartz ${ }^{16}$ plagioclase gneiss interlayered with hornblende gneiss. Pegmatites that are locally exposed in the canyon walls are readily distinguished by their very light color.

\footnotetext{
${ }^{15} \mathrm{~A}$ feldspar with the general formula of $(\mathrm{Na}, \mathrm{Ca}) \mathrm{Al}(\mathrm{Si}, \mathrm{Al}) \mathrm{Si}_{2} \mathrm{O}_{8}$.

${ }^{16}$ Mineral composed of $\mathrm{SiO}_{2}$.
} 
46.5 Large pegmatite on north side of road.

46.6 Approximate location where a 7-ton boulder landed on the highway in May 1991 (fig. 12).

47.5 Clear Creek Canyon historical marker in pullout on the left. -Nearly 400 feet of Pliocene(?) or Miocene gravel, about 1,000 feet above present-day stream level, caps the ridge (to the southwest) on the south side of Clear Creek (to right) (Reed and others, 1987).

In back of and to the right of the marker is part of the fracture zone of the Blackhawk Fault. This fault is one of the major northwest-trending faults in the region (fig. 8). The fracture zone extends to the southeast and crosses road before the next curve to the east. The Blackhawk Fault can be traced for over 22 miles in the Front Range. Just northwest of here the fault begins bending toward a more easterly trend. To the southeast, the fault passes beneath the Pliocene(?) gravel capped ridge and can be traced along a portion of Mount Vernon Canyon (Sheridan and others, 1972).

49.7 Just before Tunnel 3 -note the cribbing along Clear Creek that supported the bed of the Colorado Central Railroad. Rocks exposed along here are still predominantly amphibolite and biotite-quartz-plagioclase gneiss.

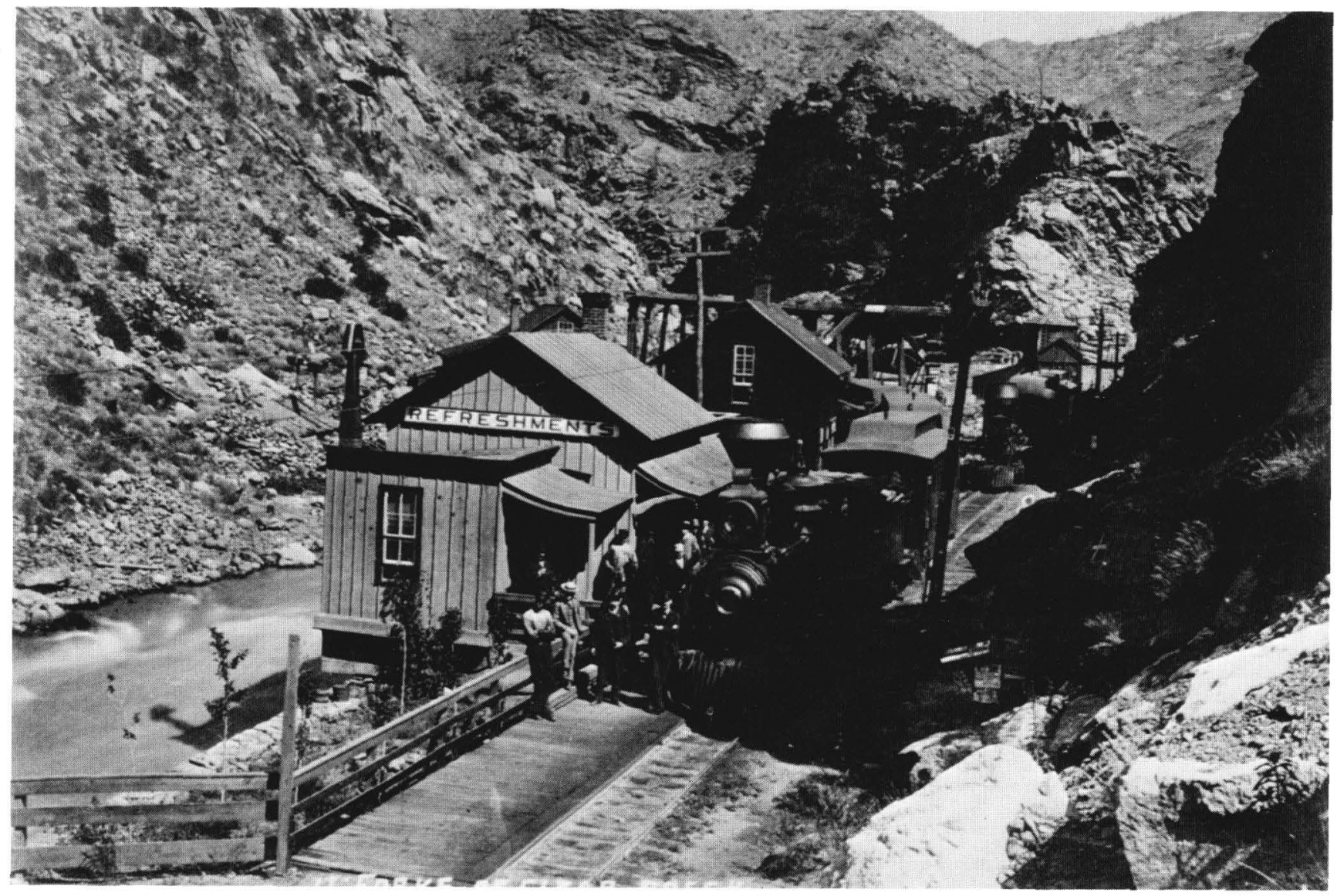

Figure 11. Narrow gauge railroad tracks at the junction of Clear Creek and North Clear Creek. Photograph by Collier. Printed courtesy of Denver Public Library Western History Collection. 


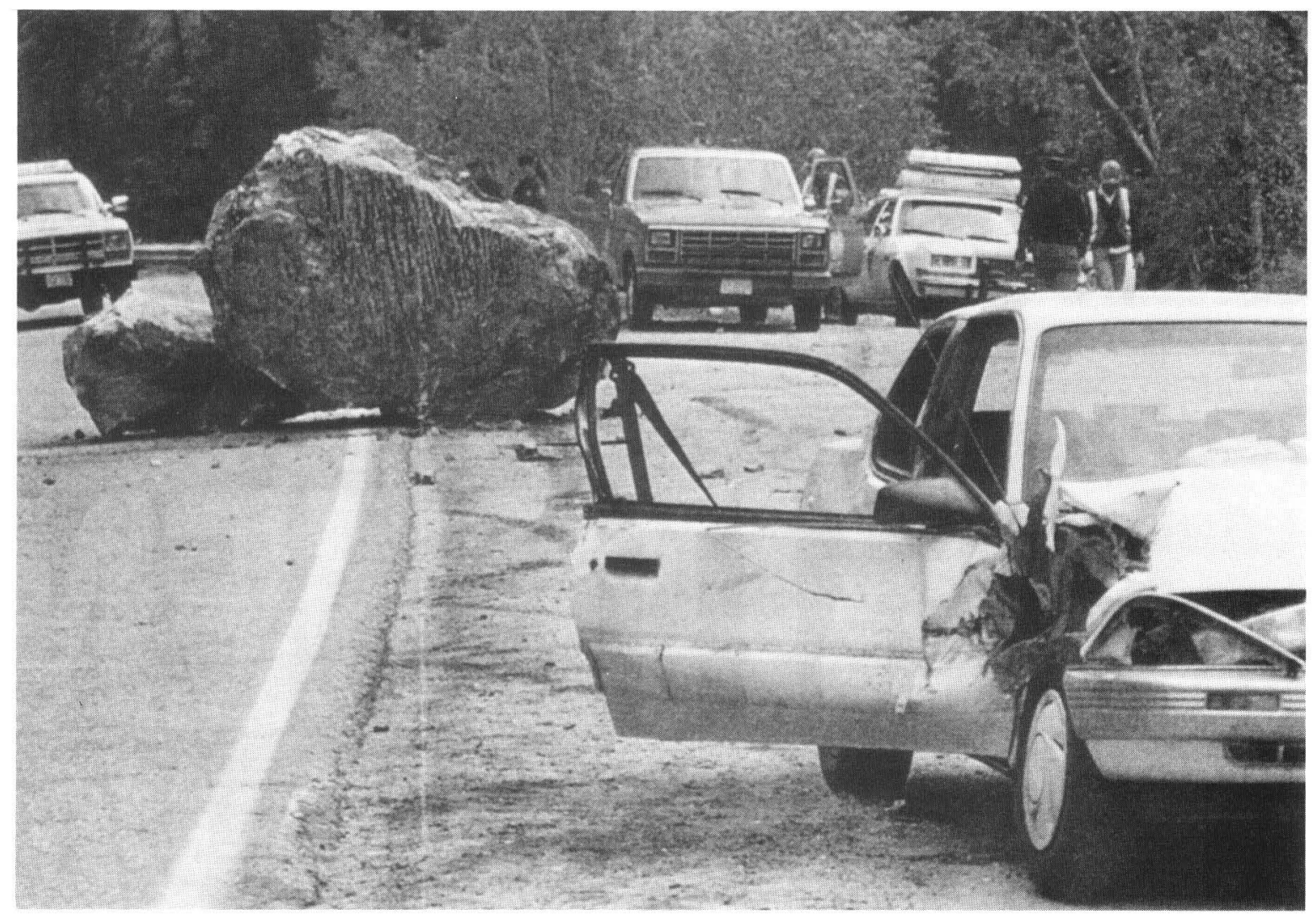

Figure 12. Seven-ton rock that fell on U.S. Highway 6 in May 1991. Denver Post photograph by John Epperson (printed with permission).

50.2 Just upstream from the east portal of Tunnel 2, the music at the Beaver Brook dance pavilion entertained tourists on day excursions from Denver in the 1880's (fig. 13). The nearby railroad station supplied water for locomotives (Hauck, 1972). For about the next mile east of Tunnel 2 the rocks are predominantly the darker migmatites.

51.8 Small side valley on the left is the former site of the Guy Gulch railroad station that was built in 1885 . Just downstream from here is another proposed dam site. To the right can be seen gneissic granodiorite.

52.5 The Junction Ranch breccia ${ }^{17}$ reef system (another major northwest-trending fault) (fig. 8) passes beneath the road at this curve. The term "breccia reef" refers to the wide zone of broken rock that is found in these fault zones. - The quarry on the north side of the road - cuts into this breccia zone exposing the yellowish-brown staining of the rocks. Many fractures here have coatings of calcite. This fault, originating in the Precambrian time, can be traced for over 25 miles in the Front Range (Sheridan and others, 1972). North of Clear Creek, the Junction Ranch fault breccia zone has a maximum width of 200 feet, but to the south, between Clear Creek and Mount Vernon Canyon the breccia zone is over 1,100 feet wide.

\footnotetext{
${ }^{17}$ Coarse-grained rock composed of angular broken rock fragments held together by a fine-grained matrix.
} 


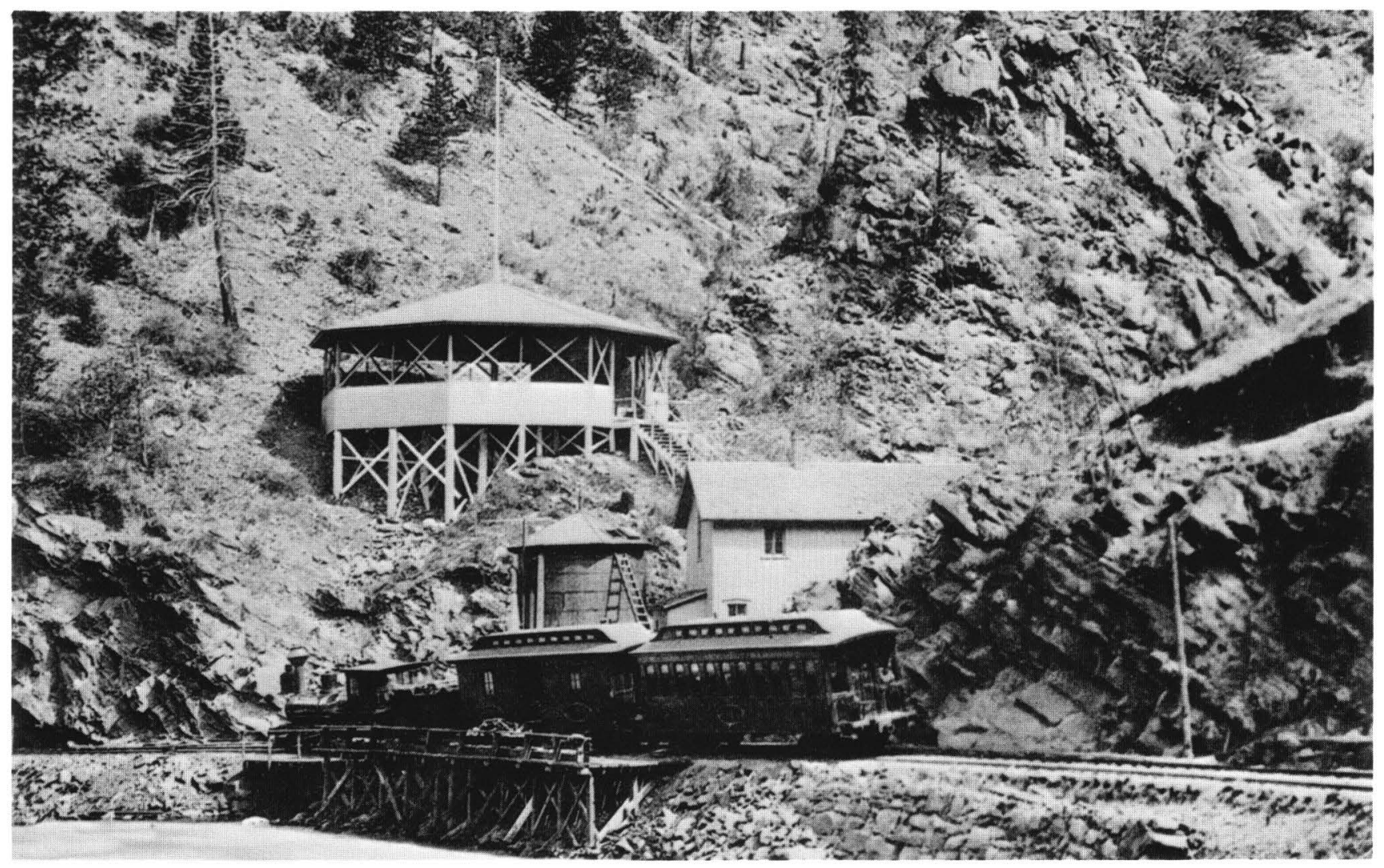

Figure 13. Beaver Creek railroad station and dance pavilion in the late 1800 's. Printed courtesy of Denver Public Library Western History Collection.

55.3 Diversion dam on the right supplies water to the Welsh ditch for irrigation of Denver's western suburbs. After passing through Tunnel 1, Welsh ditch is visible across Clear Creek.

56.6 Canyon mouth and end of road log. At the traffic light you can proceed straight ahead onto Highway 58 that returns you to eastbound I-70, or you can turn right onto U.S. Highway 6 (6th Avenue).

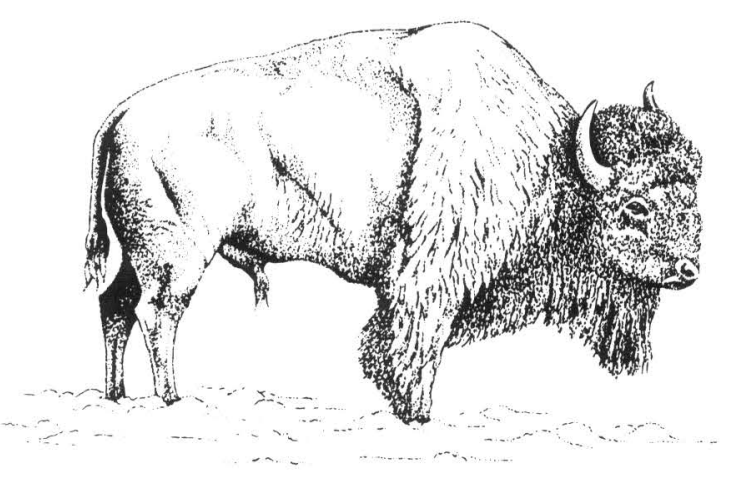




\section{REFERENCES}

Brown, R.W., 1943, Cretaceous-Tertiary boundary in the Denver Basin, Colorado: Geological Society of America Bulletin, v. 54, n. 1, p. $65-86$.

Bryant, Bruce, McGrew, L.W., and Wobus, R.A., 1981, Geologic map of the Denver $1^{\circ} \times 2^{\circ}$ quadrangle, north-central Colorado: U.S. Geological Survey Miscellaneous Investigations Series Map I-1163, scale 1:250,000.

Chronic, Halka, 1980, Roadside Geology of Colorado: Missoula, Montana, Mountain Press Publishing Co., 334 p.

Cox, Terry, 1989, Inside the Mountains: Boulder, Colorado, Pruett Publishing Company, 117 p.

Follansbee, Robert, and Sawyer, L.R., 1948, Floods in Colorado: U.S. Geological Survey Water-Supply Paper 997, 151 p.

Hafen, Leroy, 1964, Fort Vasquez: State Historical Society of Colorado, 14 p.

Hale, Jesse D., 1936, The first successful smelter in Colorado: The Colorado Magazine, v. 13, p. 161-167.

Hansen, W.R., Colton, R.B., Lindvall, R.M., and Rogers, W.P., 1976, Greater Denver urban geology field trip, in R.C. Epis, and R.J. Weimer, eds., Studies in Colorado field geology: Professional Contributions of Colorado School of Mines no. 8, p. 505-511.

Hansen, W.R., Chronic, John, and Matelock, John, 1978, Climatography of the Front Range Urban Corridor and vicinity, Colorado: U.S. Geological Survey Professional Paper 1019, 59 p.

Hansen, W.R., and Crosby, E.J., 1982, Environmental geology of the Front Range Urban Corridor and vicinity, Colorado with a section on Physical properties and performance characteristics of surficial deposits and rock units in the Greater Denver area by Ralph R. Shroba: U.S. Geological Survey Professional Paper 1230, 99 p.

Hauck, Cornelius W., 1972, Narrow gauge to Central and Silver Plume: Colorado Rail Annual Number Ten: Golden, Colorado, Colorado Railroad Museum, 224 p.

Hutchinson, R.M., White, W.H., Ward, A.D., and Ranta, D.E., 1976, Precambrian structure and early Tertiary ore deposits of the Central City-Idaho Springs mining district ( $\mathrm{Au}, \mathrm{Ag}, \mathrm{Pb}, \mathrm{Cu}$, $\mathrm{Zn}$ ) and the middle Tertiary intrusive complex at the Henderson mine (Mo, W), Front Range, Colrado, in Epis, R.C., and Weimer, R.J., eds., Studies in Colorado Field Geology: Professional Contributions of Colorado School of Mines, no. 8, p. $460-476$.

Kirkham, R.M., and Rogers, W.P., 1978, Earthquake potential in Colorado: Colorado Geological Survey Open-File Report, $131 \mathrm{p}$.

Lockley, M.G., 1988, Dinosaurs near Denver, in G.S. Holden and R.E. Tafoya, eds., Geological Society of America field trip guidebook 1988, Centennial Meeting, Denver, Colorado: Professional Contributions of Colorado School of Mines, no. 12, p. 288-299.
Morgan, Gary, 1974, Three foot rails: A quick history of the Colorado Central Railroad: Colorado Springs, Colorado, Little London Press, 38 p.

Reed, J.C., Jr., Bryant, Bruce, Grose, T.L.T., Sims, P.K., Bookstrom, A.A.. Beaty, D.W., and Mallory, W.W., 1987, Geology and mineral resources of central Colorado: Guidebook for a field trip sponsored by the Colorado Scientific Society for the Rocky Mountain Section, Geological Society of America, Boulder, Colorado, May 5 and 6, 1987, 33 p.

Robinson, C.S., Gallant, W.A., and Cochran, D.M., 1976, Land use and engineering geology of the Front Range Colorado, in R.C. Epis, and R.J. Weimer, eds., Studies in Colorado field geology: Professional Contributions of Colorado School of Mines no. 8, p. 486-504.

Schmidt, P.W., and Pierce, K.L., 1976, Mapping of Mountain soils west of Denver, Colorado, for land-use planning in Coates, O.R., ed., Geomorphology and engineering: Stroudsburg, Pa., Dowden, Hutchinson, and Ross, Inc., p. 43-54.

Scott, G. R., 1972, Geologic map of the Morrison Quadrangle, Jefferson County, Colorado: U.S. Geological Survey Miscellaneous Geologic Investigations Map I-790-A.

Scott, G.R., 1976, Historic trail map of the greater Denver area, Colorado: U.S. Geological Survey Miscellaneous Investigations Series Map I-856-G, scale 1:100,000.

Scott, G.R., and Taylor, R.B., 1986, Map showing late Eocene erosion surface, Oligocene-Miocene Paleovalleys, and Tertiary deposits in the Pueblo. Denver, and Greeley $1^{\circ} \times 2^{\circ}$ quadrangles, Colorado: U.S. Geological Survey Miscellaneous Investigations Series Map I-1626, scale 1:250,000.

Sheridan, D.M., Reed, J.C., and Bryant, Bruce, 1972, Geologic map of the Evergreen Quadrangle, Jefferson County, Colorado: U.S. Geological Survey Miscellaneous Investigations Map I-786-A.

Trimble, D.E., and Machette, M.N., 1979, Geology of the Greater Denver area, Front Range Urban Corridor, Colorado: U.S. Geological Survey Miscellaneous Investigations Series Map I-856-H, scale 1:100,000.

Trimble, D.E., Scott, G.R., and Hansen, W.R., 1992, Mountains and Plains: Denver's Geologic Setting: unnumbered U.S. Geological Survey special publication, $23 \mathrm{p}$.

Tweto, Ogden, 1975, Laramide (Late Cretaceous-early Tertiary) orogeny in the southern Rocky Mountains: in Curtis, B.F., ed, Cenozoic history of the Southern Rocky Mountains: Geological Society of America Memoir 144, p. 1-44.

1979, Geologic Map of Colorado, scale 1:500,000.

Van Horn, Richard, 1976, Geology of the Golden quadrangle, Colorado: U.S. Geological Survey Professional Paper 872, 116 p.

Waage, K.M., 1952, Clay deposits of the Denver-Golden area, Colorado: Colorado Scientific Society Proceedings, v. 15, no. 9, p. 373-390. 


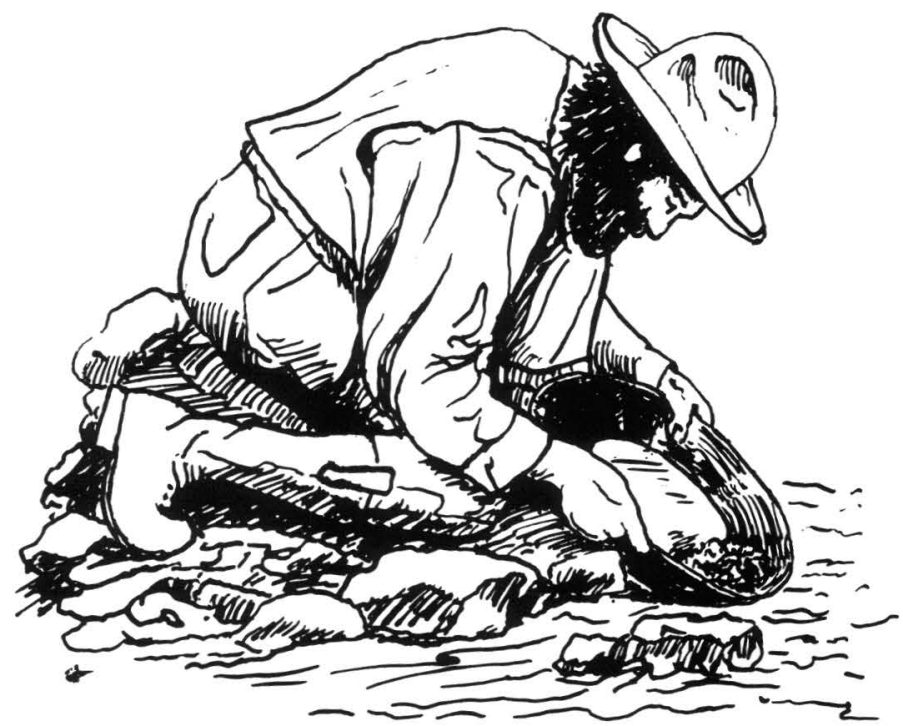




\title{
HISTORICAL NOTES
}

\author{
By Kathleen C. Stewart
}

\section{IDAHO SPRINGS}

Before the discovery of gold brought an influx of miners to the valley of Idaho Springs, abundant grass attracted herds of bighorn sheep to graze. George A. Jackson (fig. 14) could, therefore, survive by hunting as he sought placer gold in January 1859 . He camped at the mouth of Soda Creek (by Soda Creek Road, fig. 9) to take advantage of the hot springs, ate "plenty fat meat," and shot wolverines and mountain lions who also wanted his meat. After camping there several nights and exploring a few miles to the west, Jackson moved his camp one drainage upstream to Chicago Creek. He built a raging fire on the bar to thaw the gravel for panning and on January 7, 1859, he discovered gold. Five days later with an injured dog and moccasins shredded by Clear Creek ice, he limped into camp near present-day Golden and told his partner, Tom Golden, the news. Because of the winter conditions and the difficult accessibility of the area, they were unable to return until April (Hollister, 1867; Jackson, 1935).

Only a month after Jackson's return, news came from Denver of John Gregory's lode discovery near Central

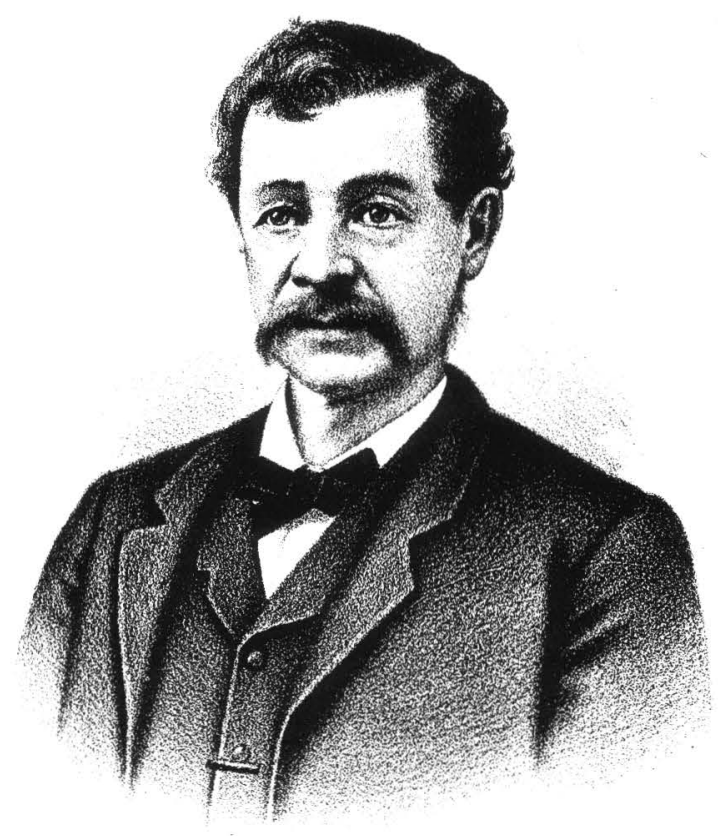

Figure 14. Portrait of George A. Jackson. Printed courtesy of Denver Public Library Western History Collection.
City-just over the mountains to the north. Men scrambled up Virginia Canyon, where the roads were later built (Virginia Canyon Road and Prospectors Trail), in a mad rush to reach and confirm the discoveries on the other side (fig. 15). Soon both valleys were filled with placer claims or "poor man's diggings." Around Idaho Springs every available gravel bar with room to stand was taken-Spanish Bar to the west, Illinois Bar, Payne's Bar and Idaho Bar in addition to Jackson's Bar (Hall, 1889; Hall, 1891; Mathews, 1940).

Over the next 2 years the individual camps blurred into one another. In 1860, F.W. Beebee moved from Illinois Bar to Idaho Bar and opened a hotel where some of the early bachelor miners could get out of their tent for a couple of days. People also came to "spectate" and see if all they had heard was true. Across the street was the log cabin saloon where miners "squandered their hard earned dust in fiery liquids, suggestive of insanity and murder" (Hall, 1891). The Colorado Territorial Legislature made "Idahoe" the county seat of newly formed Clear Creek County in 1861, but the seat was moved to Georgetown in 1867, after silver discoveries there an: in nearby Silver Plume (Hall, 1891; Bauer and others, 1990; Wright, 1986).

The placer mines survived until 1865 , but they were gradually replaced by ore mining (fig. 16). By 1861 several stamp mills for crushing ore were already in the area, including a "20-stamper" on Spanish Bar near the Stanley Mill west of Idaho Springs. The difficulty of recovering gold from ores increased, however, as the near-surface, weathered ores gave out and only the deeper sulfide ores or "sulfurets" remained. The more resistant ores were uneconomical to mine until Nathanial P. Hill built a smelter in Black Hawk in 1867-1868. Gold could be recovered by the new process, but ores had to be transported over the mountains by horses or mules (by the Virginia Canyon Road) - a very strenuous operation (fig. 15). After the railroad reached Idaho Springs in 1877 , ores could be carried by rail. Shortly afterward, Hill transferred his smelting operations to Denver in order to process ores from several areas and to benefit from lower transportation costs for coke (Cushman and Waterman, 1876; Hall, 1891; Hale, 1936).

\section{ARGO MILL AND TUNNEL}

By the 1890's many of the mines south of Central City had become so deep it was no longer economical to pump water or hoist blasted material to the surface (Cox, 1989). Because Clear Creek at Idaho Springs was nearly 1,000 feet 


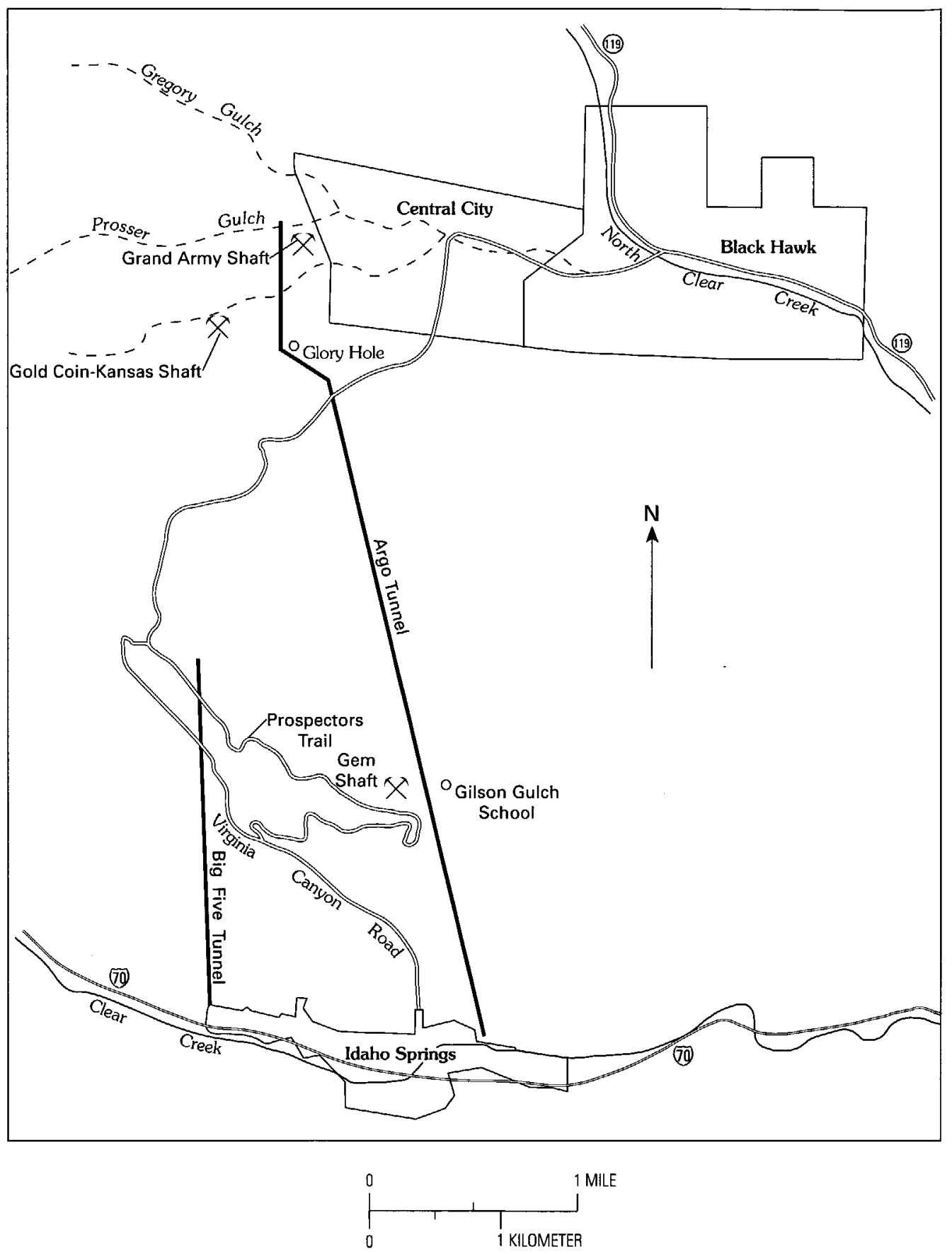

Figure 15. Map showing Argo and Big Five Tunncls in relation to Idaho Springs and Central City. Adapted from Terry Cox (printed with permission).

lower than Gregory Gulch by Central City, Samuel Newhouse and some associates had the idea of boring a tunnel through the mountains to drain mines and transport ores at the lower level. Articles of incorporation for the Argo Mining, Drainage, Transportation and Tunnel Company were filed with the Secretary of State in January 1893. The Idaho Springs News noted in October that a road had been built and that Newhouse was "preparing for work on the tunnel"
(Secretary of State Incorporation Recordings, 1893; Idaho Springs News, 1893). Locally, it was referred to simply as the Newhouse tunnel (fig. 17). Mines operating through the tunnel paid drainage and transportation fees to the company. The tunnel reached its maximum length of 4.16 miles and average depth of 1500 feet below the surface by 1910 , extending just north of Prosser Gulch west of Central City (fig. 15) (Bastin and Hill, 1917). 


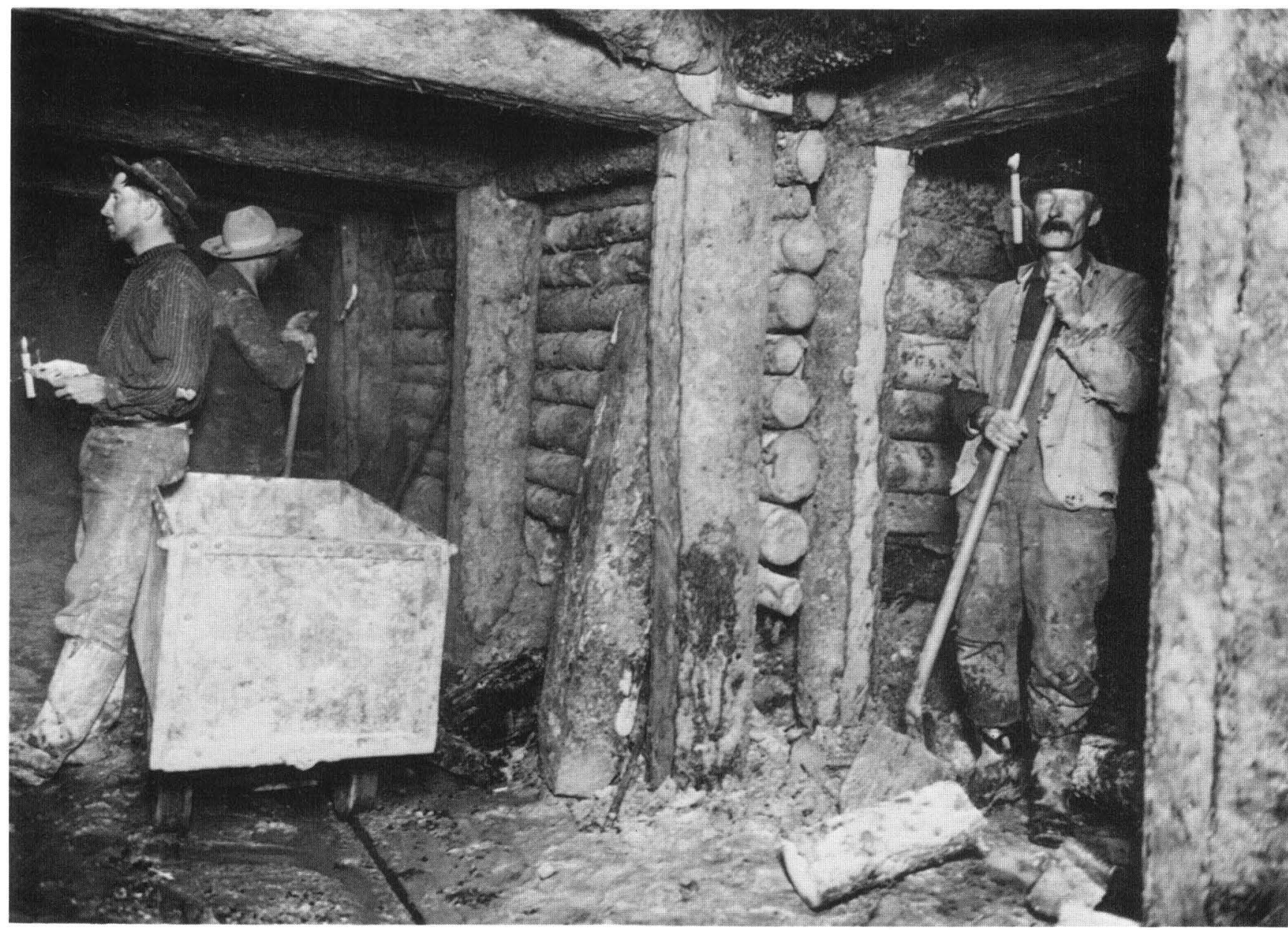

Figure 16. Early ore mining underground (probably before 1890 in Clear Creek, Gilpin, or Boulder County). These miners had only candles for light and no safety equipment. It was a cold, muddy occupation-note mud and water on miners and tunnel floor. This photograph also shows the amount of timbering necessary to support tunnel walls for access to deeper areas of the mine. Photograph by L.C. McClure, printed courtesy of Denver Public Library Western History Collection.

The company re-organized with new financing in 1899 and by 1910 the volume of ore being processed had become so large that stockholders decided to build their own mill. Articles of incorporation for the Argo Reduction and Ore Purchasing Company were filed with the Secretary of State in July 1912, and by 1913 the mill was in operation with special features to process the low-grade ores (The Denver Republican, 1899; Secretary of State Incorporation Recordings, 1912; The Idaho Springs Siftings-News, 1912, 1913).

The tunnel also benefited schools indirectly. Around 1905 , a young teacher, Beatrice Rule, rode the train slightly over a mile into the tunnel and took the platform hoist up the Gem shaft to her first job at the Gilson Gulch School (fig. 15) (History of Clear Creek County, 1986).

Business waned after World War I due to disputes with mine owners. The tunnel was cleaned and dewatered in 1926 (fig. 18) and was eventually acquired by George Collins, owner of some mines in Nevadaville. He continued to work the tunnel with the goal of intersecting the Kansas shaft (fig. 15), which had a good vein but had been allowed to flood since the 1880's and was therefore no longer mined. If he could drain the Kansas shaft through the Argo Tunnel, the vein would be his for the taking. The task of trying to intersect such deep workings was dangerous-it demanded work in dark, cold, wet conditions with foul air thrown in for good measure. Miners winced with every squirt of water when charges were set. They quit when they had a chance. When water pressure did not increase after working a stope (step-like excavation) for some weeks, Collins decided to use 10-minute fuses instead of the 30-minute fuses used previously. The decision was fatal to four men. On the afternoon of January 19, 1943, about 4 o'clock, power went out and a huge roar was heard. One man raced 200 yards to the entrance escaping in waist-deep water. According to Merle Sowell, after several minutes, water was flowing to the top and shooting across Clear Creek into downtown Idaho 


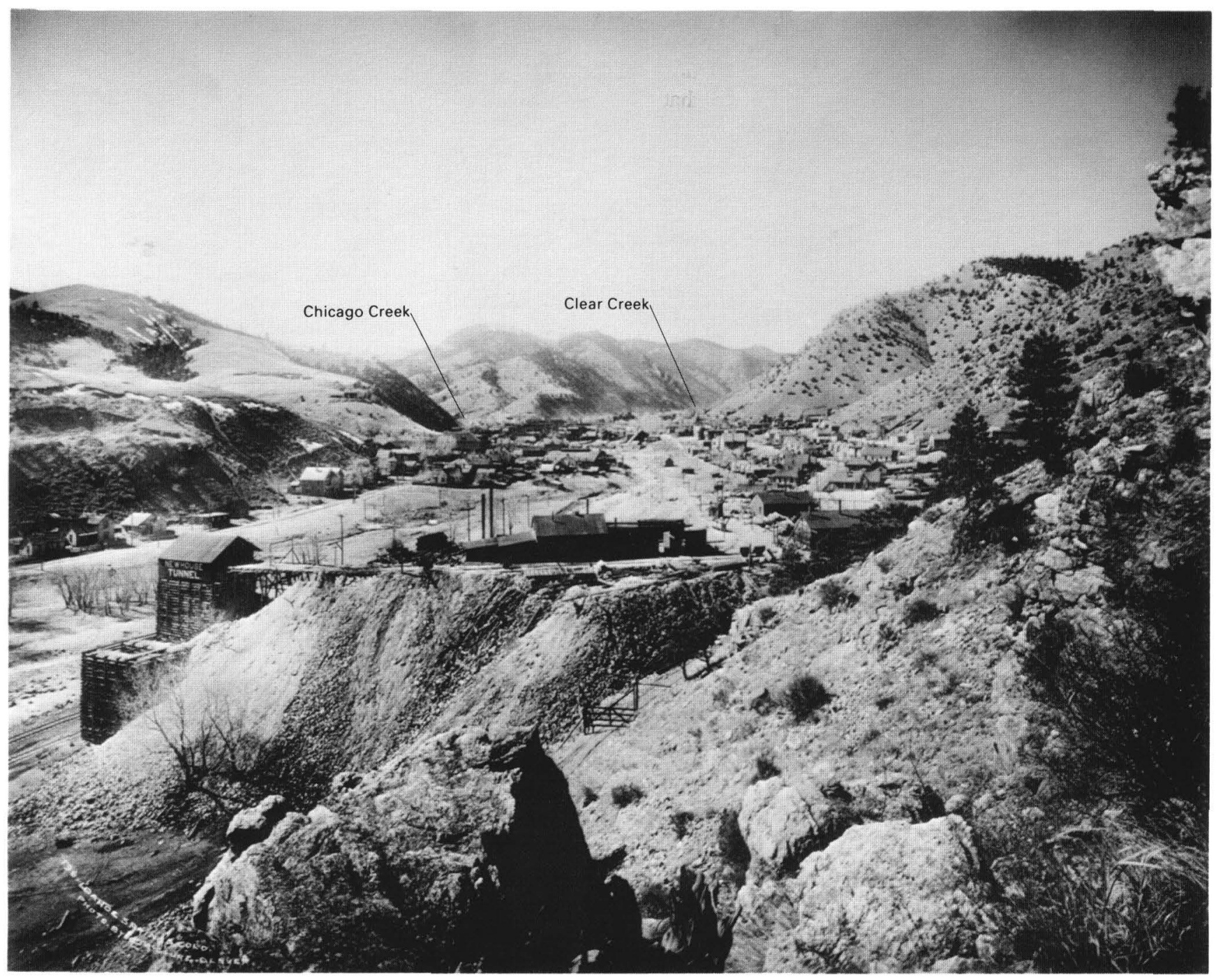

Figure 17. View of the Argo Tunnel buildings, dump, and ore loading chute. Its local designation as the "Newhouse Tunnel" is apparent from the sign on the side of the loading chute. Photograph was taken prior to 1910 looking west from the hillside behind the current mill location. The mine buildings and dump are gone today, but the dirt road (with wooden gate) still exists. The three houses

Springs. When the water subsided, the body of one miner was found covered with mud and gravel - three other bodies were found later. The tunnel was subsequently closed to mining because of lawsuits, and it has not been used for mining since, although attempts have been made to clean it out (The Denver Post, 1943; Sowell, 1974).

\section{BIG FIVE TUNNEL}

The origin of the "Big Five" is shrouded in mysterymen and companies become confused. The minutes of the Dew Drop Mine in Boulder County taken on September 2, just above and to the left of the loading chute still stand just south of Miner Street. The valley of Chicago Creek, site of Jackson's gold discovery, can be seen on the left in the distance. The valley of Clear Creek can also be seen on the right. Photograph by L.C. McClure, printed courtesy of Denver Public Library Western History Collection.

1892, state that a certificate of organization for the Orphan Boy Extension Mining and Milling Company, also in Boulder County, was filed with the Secretary of State in 1892. The incorporators were five men-N.C. Merrill, Sidney Williams, Charles H. West, Frank C. Smith, and Edwin E. Ives; but their board of directors included four additional people (one of them the sister-in-law of Merrill). By 1893, the name of William P. Daniels appears on the board of directors and on letterheads for the two companies. A letterhead mailed in February 1898, shows five companies listed under "The Big Five"-The Dew Drop Mining Company, The Dew Drop Mill Company, the Adit Mining Company, The Adit Tunnel Company, and The Ni Wot 
Mining Company, all in Boulder County. Minutes for the Big Five Tunnel, Ore Reduction and Transportation Company state that the charter was filed with the Secretary of State of Colorado in August 1900. The first shovelful of dirt was thrown for their "Central Tunnel" in December of that year, 7 years after the start of the Argo Tunnel (The Denver Times, 1900; Big Five Tunnel, 1906).

Negotiations had been rather secretive, but the tunnel was to be excavated in direct competition with the Argo (fig. 15). According to advertising, the "Big Five" had acquired ownership of all mining claims to be intersected, thereby circumventing the bookwork needed to keep track of fees and handling charges used by the Argo (fig. 18). They also advertised they would encounter ore within half a mile, in contrast to the Argo, which had blasted for a mile and a half before cutting into a good vein (The Big Five in Pen and Pencil, 1901).

By 1901, the Big Five consisted of seven or eight major stockholding companies and several minor ones. In addition to tunnels in Boulder, Gilpin, and Clear Creek Counties, they operated several in the San Juan Mountains in southern
Colorado. The names of Merrill and Daniels continually appear on letterheads, minutes, and boards of directors, in various combinations with other names that appear and disappear (Big Five Tunnel, 1906).

Despite grandiose claims to stockholders, the Big Five evidently had an image problem. In a letter dated July 1901, N. C. Merrill admonishes Wm. P. Daniels to erect billboards in addition to the big " 5 " carved in the stone over the tunnel. He says, "When they receive it (advertising circular) they have never heard of the Big Five" (Merrill, 1901). It seems that even the mine dump of the Argo was better publicity than the Big Five's small, inconspicuous bore.

They also had legal problems. A stockholder from Boston sued the company in February 1904 to prevent incorporation of yet another company and to be allowed to examine the books of the Big Five. A receiver was appointed and mining operations ceased. In March, the Colorado Supreme Court issued an injunction to allow operations to continue, but news of the Big Five disappeared from mining journals after November 1904 (Mining Reporter, 1904 a, b, c). The tunnel was extended to about 9000 feet in the 1930's and was

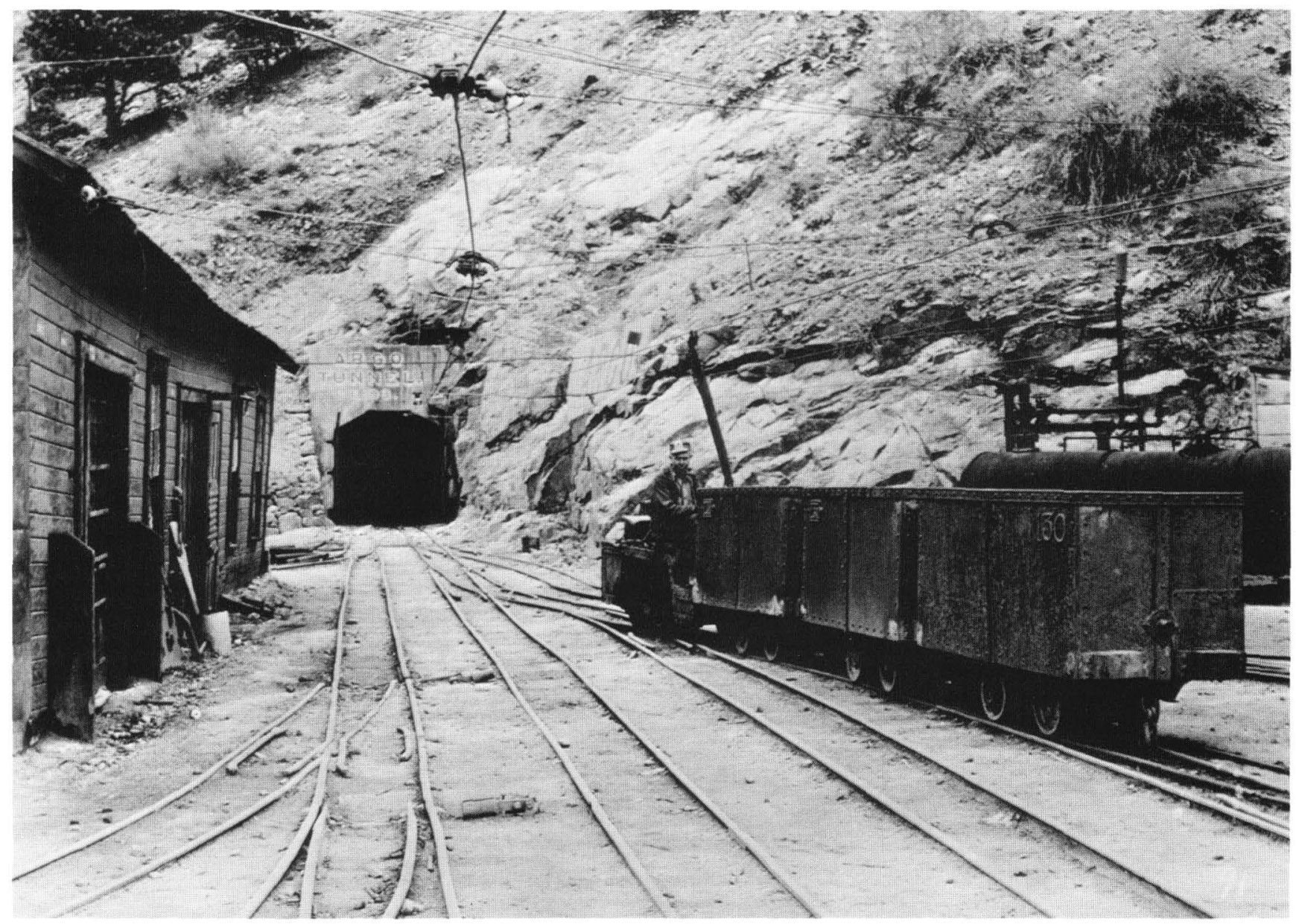

Figure 18. Argo Tunnel in operation during the 1930's. Printed courtesy of Denver Public Library Western History Collection. 
mined some in the 1960's. It is now owned by George Groves, Jr., who lives in New York City. The Big Five is scarcely referred to in historical accounts of Idaho Springs and mostly in reference only to the hot springs, another of Merrill's ventures. Although fire destroyed the remnants of Big Five properties in Boulder County at Ward in 1970, some buildings and rails from the Big Five Tunnel are still in place in Idaho Springs (fig. 19) (Al Hoyl, Clear Creek Mining Company, oral commun., 1991; Rocky Mountain News, 1970).

\section{CHARLEY TAYLER WATER WHEEL}

Charley Tayler built his original wheel in 1893 (fig. 20) to power a stamp mill on Ute Creek, a small drainage that empties into Chicago Creek about 4 miles southwest of Idaho Springs on the way to Mount Evans.

In 1945, the wheel was donated to the town of Idaho Springs. It was dismantled and reassembled in its present location by the Chamber of Commerce as a tourist attraction. In 1973, the Henderson Mine made drawings of the individual pieces and rebuilt the wheel using much of the old structure. By this time the wheel had deteriorated badly, and the partial reconstruction ended up serving only as a temporary measure, because it soon ground to a halt again. In 1988, Idaho Springs residents started a major reconstruction effort. Using donated time, materials, and expertise, massive concrete foundations were poured, new supports were constructed, and the hub and axle were hoisted into place. On the basis of drawings from the previous reconstruction, new wooden components were attached to the hub with many of the original metal parts. The hub and axle constitute fully one-quarter of the total weight of 6000 pounds. Because of its tremendous weight, the wheel is furnished with solderlike bearings that prevent wear of the axle and can be poured in place when replacement is needed. The wheel is also equipped with special fittings for greasing from ground level.

Water flowing to the wheel and the waterfall to its left come from an overflow pipe of the water supply to Idaho Springs. The water is diverted from its natural path either to the falls, the wheel, or both. During the winter, all water flow is diverted to the falls to prevent ice damage to the wheel (Wendell Upright, Colorado Department of

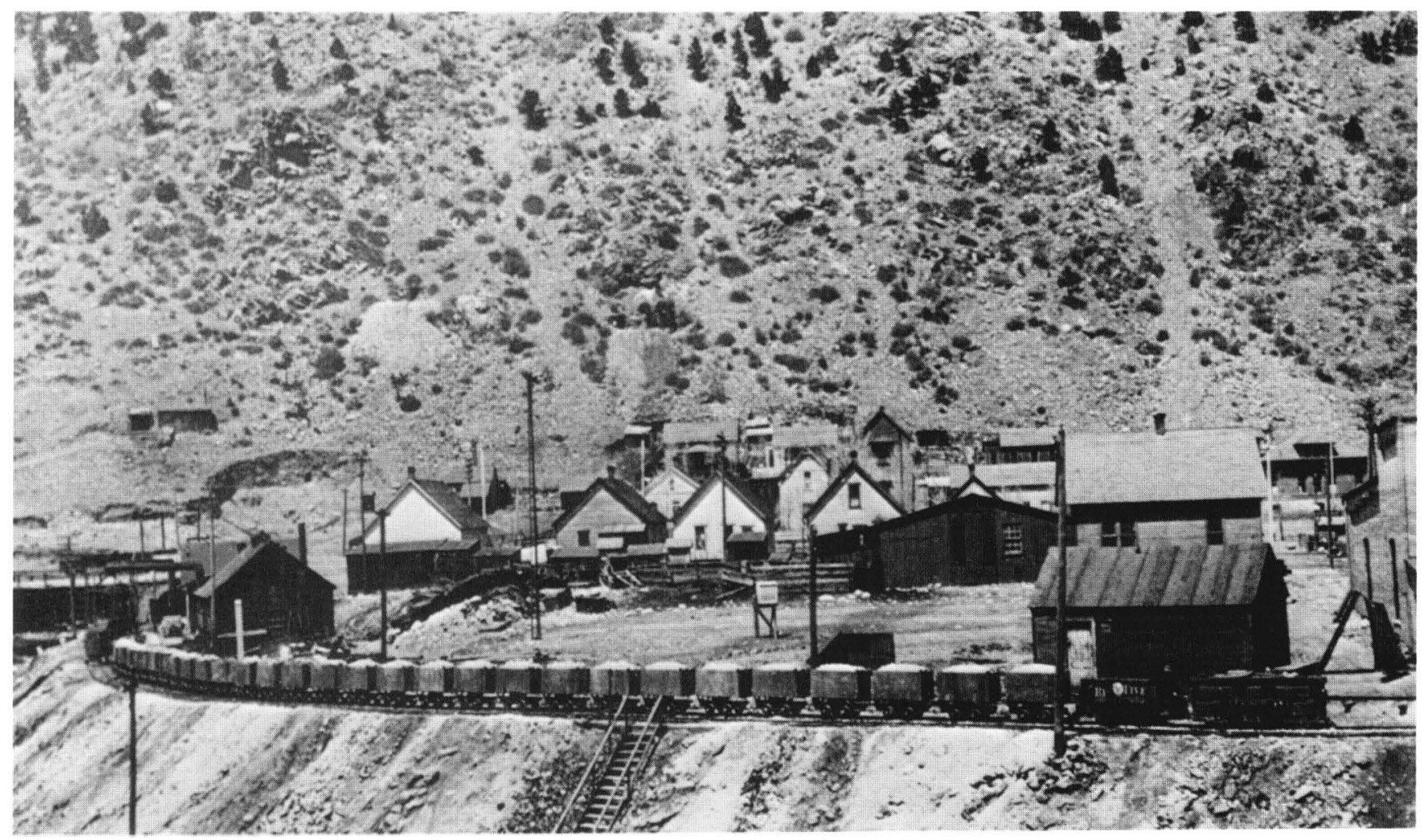

Figure 19. Ore cars of the Big Five Tunnel on their way to the mill. Adit is barely visible behind building on the left. Photograph is taken between 1900 and 1910 from the south side of Clear Creek looking north. I-70 now obscures this view, crossing the tracks above the stairway at the level of the road in the background. Shed visible at far left no longer exists, but one behind it and the four houses still stand. Denver Public Library Western History Collection (printed with permission). 


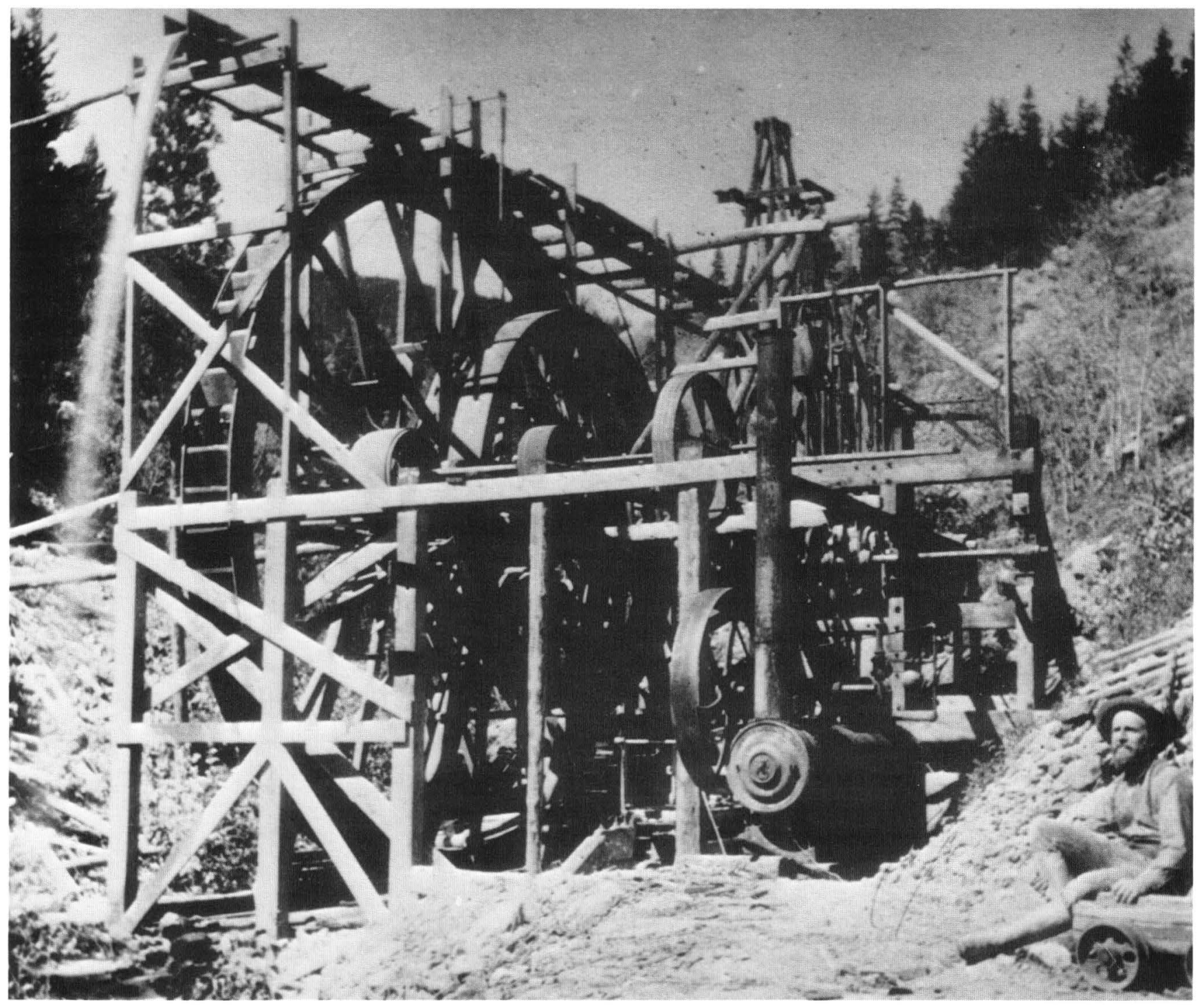

Figure 20. Charley Tayler (far right) with his water wheel sometime after its construction in 1893. Printed courtesy of Idaho Springs Historical Society.

Transportation, and Bruce Bell, Idaho Springs Historical Society, written commun., 1991).

\section{HOT SPRINGS}

The hot springs Jackson used were known to Ute, Arapahoe, Apache, Kiowa, and Comanche In dians because possession of the territory had changed hands many times prior to its discovery by gold seekers. The best theories of the origin of the name "Idaho" are based on corruption of Indian words. In 1861, the area was "ceded" to the United States by the Arapahoe and Cheyenne Indians and soon thereafter became part of Colorado Territory (Mathews, 1940; Dawson, 1954; Erickson and Smith, 1985). The first attempt to commercialize the springs came 2 years later when Dr. E.M. Cummings acquired the land and built a wooden bathhouse. From that time forward people paid to use the springs but at least they were indoors and out of the cold. In 1866, Harrison Montague bought the property and built a more substantial stone structure. Montague's son-in-law replaced the bathhouse in 1899 with the "natatorium" (fig. 21). In this era it became popular for tourists to stop and drink the mineral water (Hall, 1891; The Denver Times, 1899).

Operators of the Big Five Tunnel bought the property in early 1900 and excavated a tunnel network in the mountain to further commercialize the hot springs. That network is still present today. About 1910, a property-holding company acquired the operation and in the 1920's attempted to develop it as a sanitarium for polio called "The Radium 


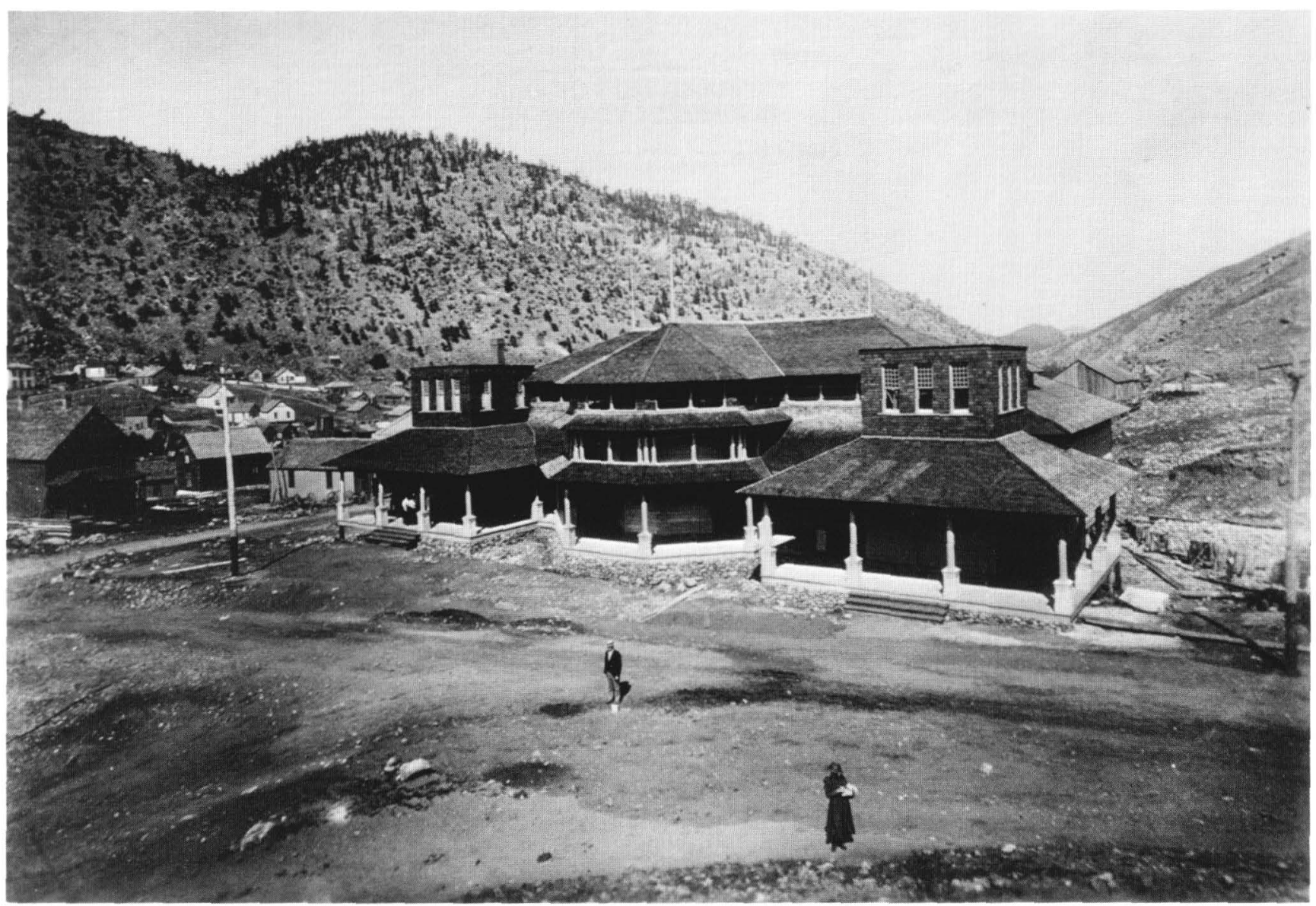

Figure 21. The Idaho Springs Natatorium in the early 1900's. Printed courtesy of Denver Public Library Western History Collection.

Hot Springs" (N.C. Merrill was still on the board). Advertising stated, "Come and Drink the Water. It is FREE. The Radium Water, taken internally, radiates outward, as if the sun were shining out from inside" (Radium Hot Springs Records, 1924-1930).

During this time the main hotel was built. The names of many celebrities have appeared in guest books over the years-Frank and Jesse James, H.A.W. Tabor, and Walt Whitman, to mention a few (History of Clear Creek County, 1986; Radium Hot Springs Records, 1924-1930). Today the hot springs is still a commercial resort.

\section{ACKNOWLEDGMENTS}

I would like to thank the following for their help with this history: Marjorie Bell of Idaho Springs was a very patient initial and continuing source of information; Mary Jane Loevlie, also of Idaho Springs, kindly obtained the print of Charlie Tayler; the entire staff of the Denver Public Library's Western History Collection was generous with their help to obtain documentation and photographs; the staff of the U.S. Geological Survey and Bureau of Mines
Libraries helped obtain and reproduce photographs and documentation; the staff of the Colorado State Archives assisted with document verification; and my sister Mary Stewart edited the first draft.

\section{REFERENCES}

Bastin, Edson S., and Hill, James T., 1917, Economic Geology of Gilpin County and Adjacent Parts of Clear Creek and Boulder Counties, Colorado: U.S. Geological Survey Professional Paper 94, 379 p.

Bauer, William, H., Ozment, James L., and Willard, John H., 1990, Colorado Post Offices 1859-1989: Golden, Colorado, Colorado Railroad Museum, $280 \mathrm{p}$.

Big Five Tunnel, 1906, Ore Reduction and Transportation Company Records, 1892-1906: Western History Collection, Denver Public Library. [Collection of records and correspondence]

Cox, Terry, 1989, Inside the Mountains: Boulder, Colorado, Pruett Publishing Company, $117 \mathrm{p}$.

Cushman, Samuel and Waterman, J.P., 1876, The Gold Mines of Gilpin County, Colorado: Historical, Descriptive and Statistical: Central City, Colorado, Register Steam Printing House, $136 \mathrm{p}$. 
Dawson, J. Frank, 1954, Place names in Colorado: Denver, Colorado, Golden Bell Press, 72 p.

Erickson, Kenneth A. and Smith, Albert W., 1985, Atlas of Colorado: Boulder, Colorado, Colorado Associated University Press, 73 p.

Hale, Jesse D., 1936, The first successful smelter in Colorado: The Colorado Magazine, v. 13, p. 161-167.

Hall, Frank, 1889, History of the State of Colorado: Chicago, Illinois, Blakely Printing Company, v. 1, 564 p.

-1891, History of the State of Colorado: Chicago, Illinois, Blakely Printing Company, v. 3, 518 p.

History of Clear Creek County-Tailings, Tracks, and Tommyknockers, 1986: Denver, Colorado, Specialty Publications, Inc., $451 \mathrm{p}$.

Hollister, Ovando J., 1867, The Mines of Colorado: Springfield, Massachusetts, Samuel Bowles and Company, $450 \mathrm{p}$.

Idaho Springs News, 1893, Mining and Milling: Idaho Springs News, October 13, 1893, p. 4.

Jackson, George A., 1935, Diary 1858-1859, in L.R. Hafen (ed.): The Colorado Magazine, v. 12, p. 202-214.

Mathews, Ruth Estelle, 1940, A Study of Colorado Place Names: Masters Thesis, Stanford University, 473 p.

Merrill, N.C., July 25, 1901, personal letter to Wm. P. Daniels: Denver Public Library, Western History Collection [collection of records and correspondence].

Mining Reporter, 1904a, The Big Five litigation: Denver, Colorado, Mining Reporter Publishing Company, February 11, 1904, p. 138.

1904b, Receiver appointed for Big Five Mining Co.: Denver, Colorado, Mining Reporter Publishing Company, February 25, 1904. p. 195. 1904c, Mining News, Clear Creek County: Denver, Colorado, Mining Reporter Publishing Company, November 17, 1904, p. 533.

Radium Hot Springs Records, 1924-1930, Idaho Springs, Colorado: Denver Public Library, Western History Collection [collection of records and correspondence].

Rocky Mountain News, 1970, Big Five mine at Ward destroyed in fire: Rocky Mountain News, August 8, 1970, p. 44C.

Secretary of State Incorporation Recordings, 1893: Colorado State Archives, v. 33, p. 474.

1912, Colorado State Archives, v. 157, p. 477.

Sowell, Merle, 1974, Four men drowned on Saturday in January 1943: Front Range Journal, August 12, p.12.

The Big Five in Pen and Pencil, "V," October, 1901: Denver, Colorado, Carson-Harper Company, (unpaged).

The Denver Post, 1943, Argo tunnel flood traps four and one body is recovered: The Denver Post, January 19, 1943, p. 1.

The Denver Republican, 1899, Re-organization of the Newhouse Tunnel Company: The Denver Republican, April 14, 1899, p. 8 , col. 3 .

The Denver Times, 1899, Idaho Springs, a health resort and mining center: The Denver Times, May 21, 1899. p. 17.

1900, The Big Five at Idaho Springs: The Denver Times, December 30, 1900, pt. 2, p. 3, col. 5.

The Idaho Springs Siftings-News, 1912, The mining outlook for 1913: The Idaho Springs Siftings-News, December 28, 1912, no page.

1913, Purchase of ores F.O.B. Argo Mill: The Idaho Springs Siftings-News, February 8, 1913, no page.

Wright, Jim, 1986, Clear Creek County in History of Clear Creek County: Tailings, Tracks and Tommyknockers: Denver, Colorado, Specialty Publications, Inc., 451 p.

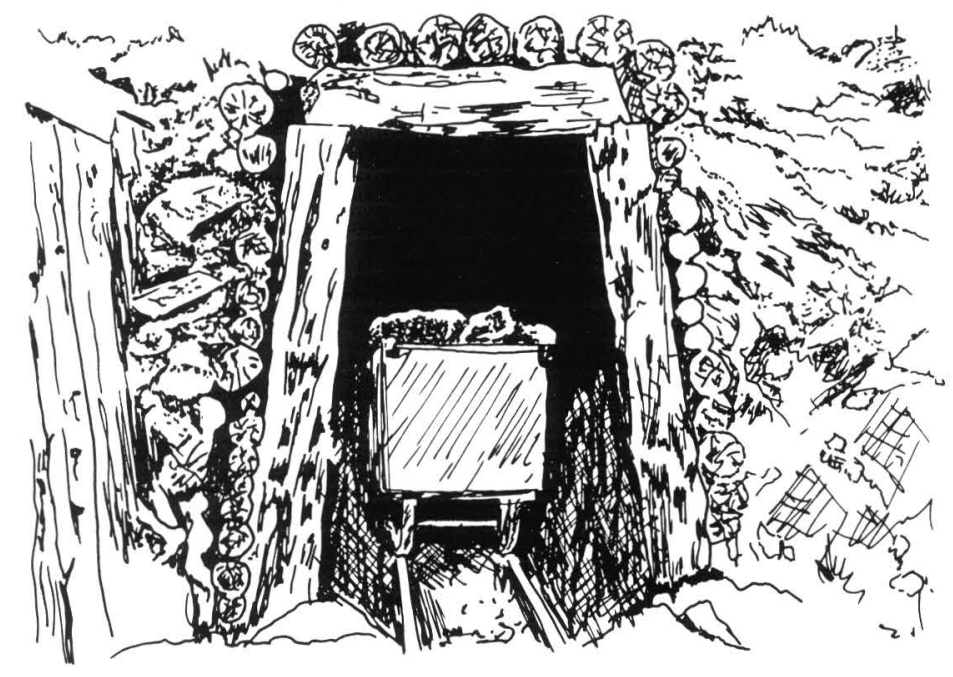




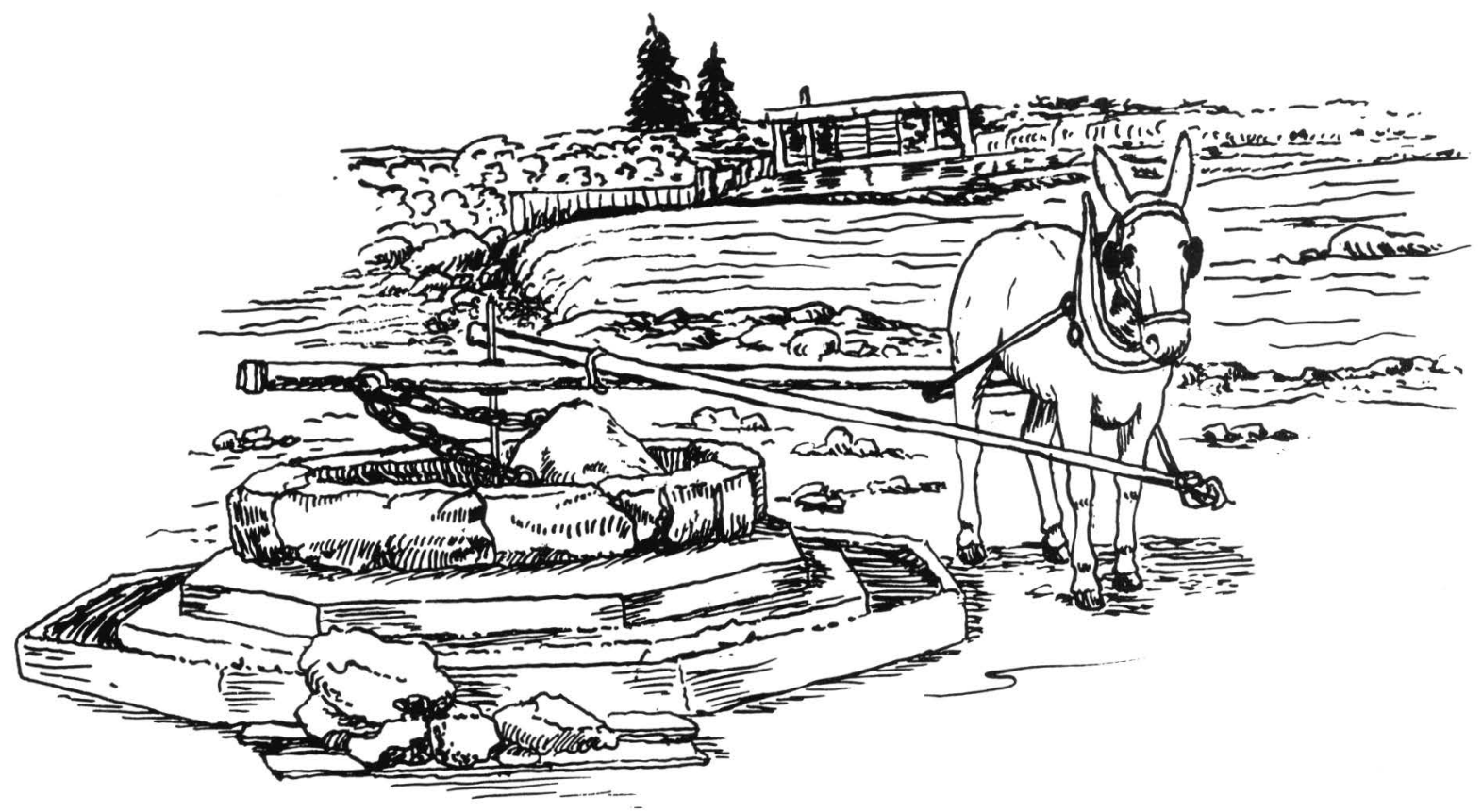

Arrastre 


\title{
GEOLOGY AND MINERALIZATION OF THE IDAHO SPRINGS AND CENTRAL CITY MINING DISTRICTS
}

\author{
By Helen W. Folger
}

In the years between 1860 and 1950 , the Central City and Idaho Springs Mining Districts produced much gold and silver from sulfide ores. The ore deposits formed principally along fault fissures in Precambrian granites, gneiss, and schist, during Tertiary time.

\section{IDAHO SPRINGS AND CENTRAL CITY MINING DISTRICTS}

The mining towns of Idaho Springs and Central City are located approximately 30 miles due west of Denver in the Front Range of the Rocky Mountains. The Front Range includes the area from the Wet Mountains on the south, northward along the Arkansas River to the Laramie Range, and from the Park, Mosquito, and Sawatch Ranges on the west, eastward to the Denver Basin and Great Plains (fig. 22). The core of the Front Range is composed of Precambrian granites, gneiss, and schist that were uplifted during Late Cretaceous time along a north-south-trending anticline. The overlying Paleozoic and Mesozoic sedimentary rocks have since been eroded away along the crest leaving steeply dipping beds along its flanks (fig. 3). The Idaho Springs and Central City Mining Districts lie in the Colorado Mineral Belt- a zone of mineralization that runs northeast to southwest from Boulder through Breckenridge to the San Juan Mountains in southwest Colorado.

The most favorable host rocks for mineral deposition were the Precambrian migmatites ${ }^{18}$ (including the Idaho Springs Formation), hornblende gneiss, and the Boulder Creek Granodiorite, Silver Plume, and Pikes Peak Granites (table 1). Openings and fissures formed by the faulting (fig. 8) became ideal sites for mineral deposition by fluids ascending from deep magma ${ }^{19}$ sources. Sulfide-bearing quartz veins and stockwork ${ }^{20}$ formed along east and northeast-trending faults near intersections with northwesttrending faults. In most instances the northwest-trending

\footnotetext{
${ }^{18} \mathrm{~A}$ composite rock composed of igneous and metamorphic materials.

${ }^{19}$ Molten rock.

${ }^{20}$ Ore composed of closely spaced irregular-shaped veinlets in a host rock. The whole rock is milled as opposed to just the vein material.
}

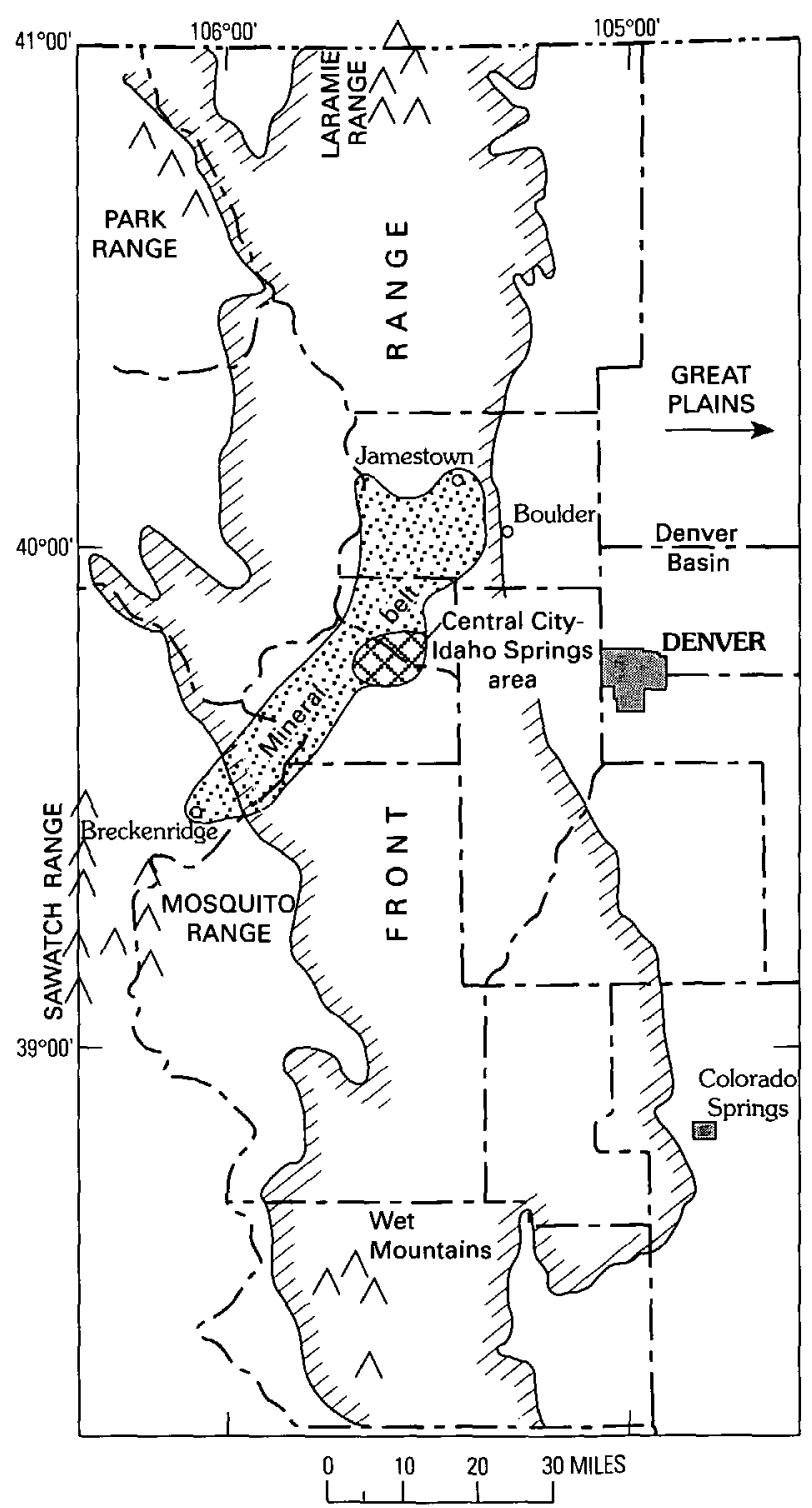

Figure 22. Map outlining the Front Range in Colorado and showing the location of the Central City and Idaho Springs Mining Districts in the Colorado Mineral Belt (modified from Sims, 1960).

faults influenced the ore-fluid movement through the area, but are themselves unmineralized (Lovering and Goddard, 1950). 


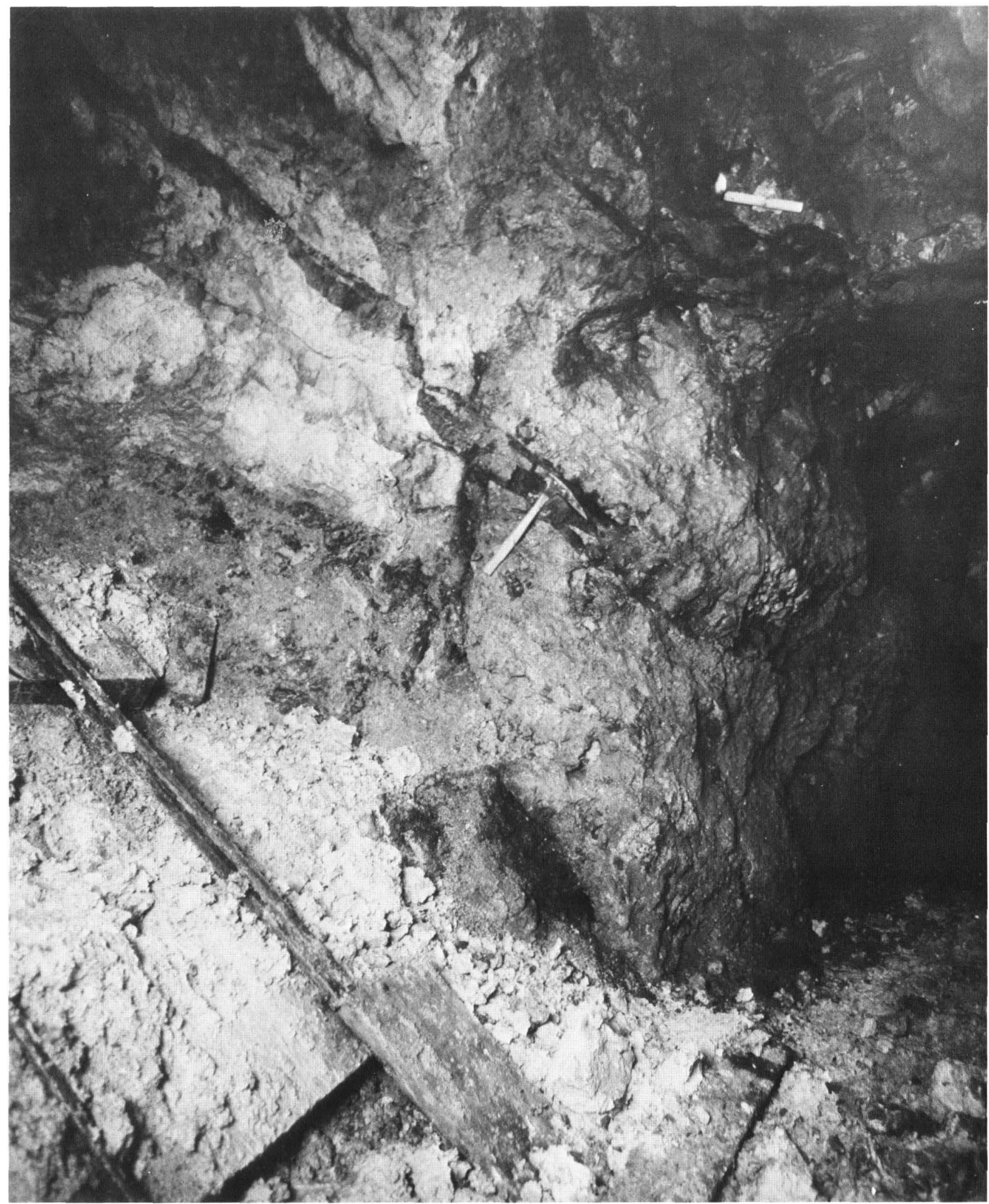

Figure 23. Location of an ore vein marked by a hammer. This is probably a pyritic ore vein in Clear Creek or Gilpin County. Photograph was taken in the mid-nineteenth century-note flame of burning candle that was used for light. Printed courtesy of Denver Public Library Western History Collection. 


\section{PRIMARY ORES}

Ores of the Central City and Idaho Springs Mining Districts were mined principally for gold and silver, although substantial amounts of copper, lead, zinc, and uranium were also recovered. In 1917, Bastin and Hill published the first comprehensive report on the two districts. Their report described the geology and production and gave detailed descriptions of the ores mined in the district. They classified the ores according to mineralogy into six types (from oldest to youngest): uranium ores, pyritic ores ${ }^{21}$, galena-sphalerite ores ${ }^{22}$, composite ores, telluride ores ${ }^{23}$, and placer deposits.

The primary uranium ore mineral is uraninite ${ }^{24}\left(\mathrm{UO}_{2}\right)$. Uraninite is found in a gray-quartz gangue ${ }^{25}$ with smaller amounts of chalcopyrite $\left(\mathrm{CuFeS}_{2}\right)$ and pyrite $\left(\mathrm{FeS}_{2}\right)$. Both pyritic and galena-sphalerite ores frequently contain recoverable amounts of uraninite. Sims and others (1963) believe that uranium mineralization took place prior the main sulfide (pyritic) mineralization. It occurs sporadically with other sulfides throughout the districts.

Pyritic ores are the most widely distributed in the district (fig. 23). Their main constituents are pyrite $\left(\mathrm{FeS}_{2}\right)$ and gangue with smaller amounts of chalcopyrite $\left(\mathrm{CuFeS}_{2}\right)$, tennantite $\left(\mathrm{Cu}_{12} \mathrm{As}_{4} \mathrm{~S}_{13}\right)$, gold $(\mathrm{Au})$, and occasionally enargite $\left(\mathrm{Cu}_{3} \mathrm{AsS}_{4}\right)$. Small amounts of galena $(\mathrm{PbS})$, sphalerite $(\mathrm{ZnS})$, molybdenite $\left(\mathrm{MoS}_{2}\right)$, and native bismuth $(\mathrm{Bi})$ also occurred in some deposits. Gold and silver are most often associated with the chalcopyrite and enargite minerals (Lovering and Goddard, 1950).

The galena-sphalerite ores were deposited later than the pyritic ores. These ores are composed predominantly of galena, sphalerite, and smaller amounts of pyrite. Some chalcopyrite, tennantite, and bornite $\left(\mathrm{Cu}_{5} \mathrm{FeS}_{4}\right)$ are also present. Similar to pyritic ores, the gold is associated more with chalcopyrite and tennantite than with pyrite (fig. 24). In contrast to the pyritic ores, the galena-sphalerite ores are poorer in gold and copper but richer in silver. Quartz $\left(\mathrm{SiO}_{2}\right)$, calcite $\left(\mathrm{CaCO}_{3}\right)$, and siderite $\left(\mathrm{FeCO}_{3}\right)$ are the most common gangue minerals, but rhodochrosite $\left(\mathrm{MnCO}_{3}\right)$ and barite $\left(\mathrm{BaSO}_{4}\right)$ are abundant in some veins.

The composite ores are composed of both the pyritic ores and the galena-sphalerite ores. Composite ores are thought to be the result of double mineralization along a fracture or vein where renewed fault movement created new space for later ore deposition (Lovering and Goddard, 1950). As faults were reactivated, pyritic ores were broken and overlain by the galena-sphalerite ores. In some veins signif-

\footnotetext{
${ }^{21}$ Ores that contain a large percentage of pyrite $\left(\mathrm{FeS}_{2}\right)$.

${ }^{22}$ Ores that contain abundant galena $(\mathrm{PbS})$ and sphalerite $(\mathrm{ZnS})$.

${ }^{23}$ Ores that contain the element tellurium.

${ }^{24}$ Also known as pitchblende.

${ }^{25}$ The valueless mineral or rock associated with ores.
}

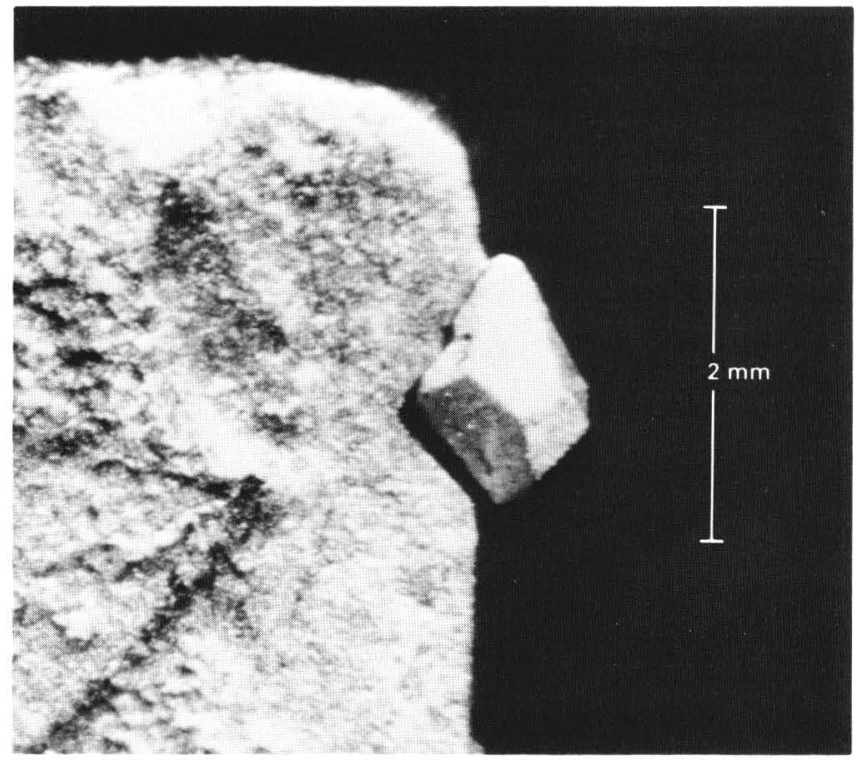

Figure 24. Unusual occurrence of a gold crystal resting on the edge of a galena crystal. Specimen idnetified as coming from the Leadville Mining District. Photograph by Richard B. Tripp, U.S. Geological Survey.

icant brecciation ${ }^{26}$ of the pyritic ores occurred prior to the galena-sphalerite ore deposition. The gold plus silver content of these ores varies considerably from deposit to deposit.

Telluride ores are composed of gold, silver, and tellurium in a gangue of quartz, fluorite $\left(\mathrm{CaF}_{2}\right)$, calcite, and fine-grained pyrite. They are a later stage of mineralization than the pyritic and galena-sphalerite type ores and formed networks along fractures and in the adjacent wall rock. Only a few telluride-bearing veins that occur along a narrow fault zone northeast of Central City are found in this district. Lovering and Goddard (1950) suggested that they were rare because only a few faults tapped the source of the gold-telluride enriched ore fluids. Some of the tellurides identified include altaite $(\mathrm{PbTe})$, krennerite $\left(\mathrm{AuTe}_{2}\right)$, petzite $\left(\mathrm{Au}_{3} \mathrm{AgTe}_{2}\right)$, and sylvanite $\left((\mathrm{Au}, \mathrm{Ag})_{2} \mathrm{Te}_{4}\right)$.

Placer deposits were formed by the weathering of pyritic gold ores and were the first deposits to be discovered and worked by early miners. Surface exposures of goldbearing sulfides disintegrated because of weathering processes, thereby freeing the gold. Flowing water concentrated the free gold into pockets or bars of gravel along stream bottoms. Large-scale placer mining did not become economically important until the 1930's, when the first dry dredge worked on Clear Creek east of Idaho Springs and later on North Clear Creek (fig. 25). It is estimated that more than 100,000 fine ounces of gold and 158 fine ounces of silver were recovered from placers in these districts.

\footnotetext{
${ }^{26}$ Breaking and crushing into angular fragments.
} 


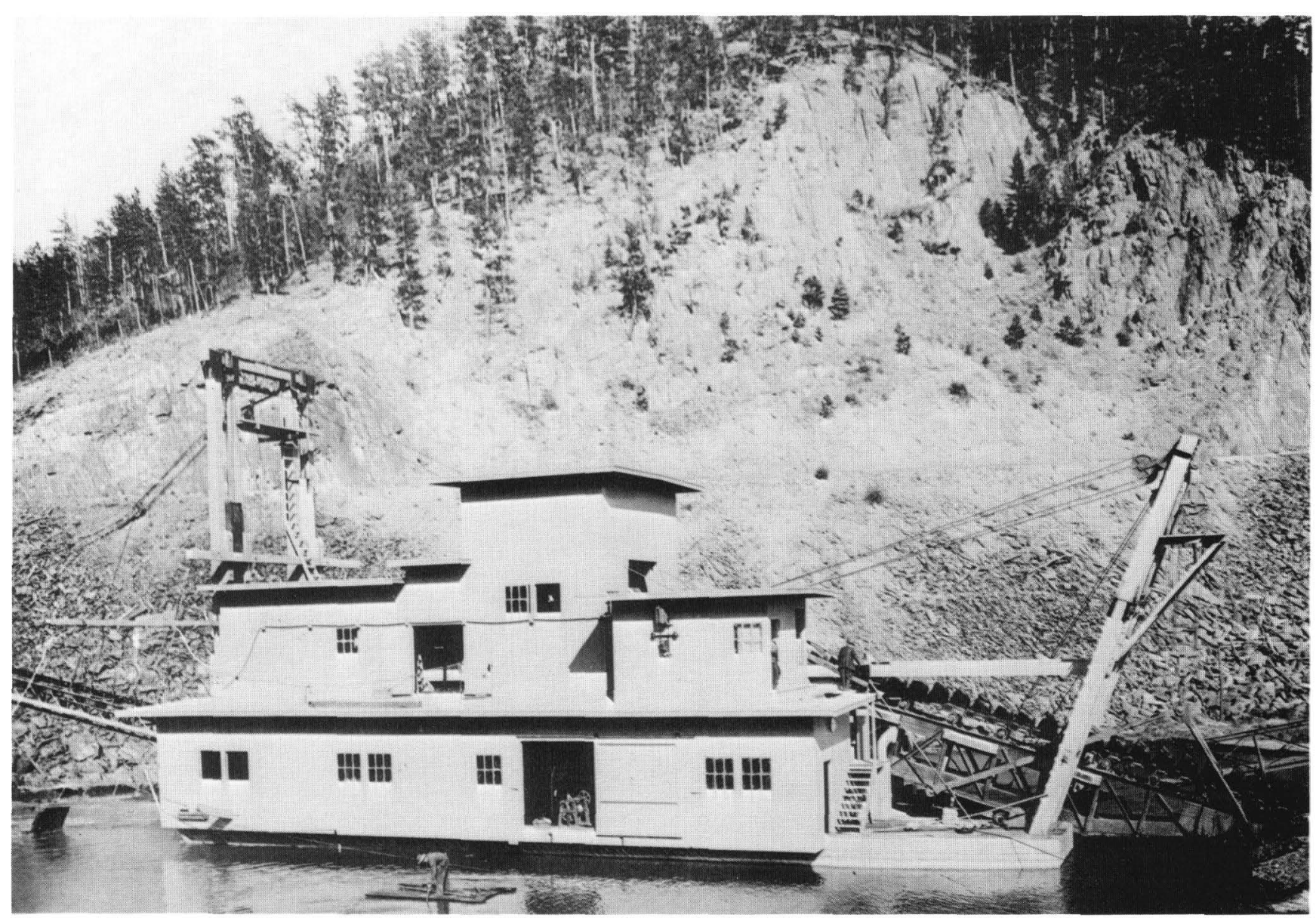

Figure 25. Hydraulic dredge mining placer deposits along Clear Creek sometime between 1930 and 1941. Printed courtesy of Denver Public Library Western History Collection.

\section{RECENT STUDIES}

In 1950, Lovering and Goddard studied the paragenetic sequence $^{27}$ of mineralization in the Idaho Springs and Central City Districts and described how it related to other deposits in the Mineral Belt. They found a close association between the mineralization of these two districts. In 1963, Sims and others, recognized that certain sulfide minerals formed concentric zones around the mining districts (fig. 26). The zonal pattern is believed to have resulted from the upward and outward movement of hydrothermal fluids ${ }^{28}$ from a source beneath the central zone (Sims and others, 1963). The different zones reflect the transitions from a core deficient in base-metals ${ }^{29}$ and rich in pyrite to a peripheral

\footnotetext{
${ }^{27}$ The sequential ordering of mineral deposition in an ore deposit.

${ }^{28}$ Heated watery fluids that carry elevated concentrations of some elements. Ore deposits form by precipitation of these elements as minerals.

${ }^{29}$ Base-metals generally refers to the transition elements in the periodic chart, in particular $\mathrm{Cu}, \mathrm{Pb}$, and $\mathrm{Zn}$.
}

zone where base-metal sulfides predominate and pyrite is absent. Gold occurs mostly in and near the intermediate zone, and silver increases outward from the intermediate zone to the peripheral zone (Sims and Barton, 1962).

\section{ORE ENRICHMENT}

After the hydrothermal system waned, lower temperature ground waters further enriched ores in gold and silver. These hydrochemical processes were less important for copper and negligible for lead and zinc. Oxidized surface waters dissolved the sulfides and carried the metals downward to the water table. Gold enrichment, therefore, occurred mostly in the areas directly above and below the water table. This resulted in a dramatic increase in the content of native (elemental) gold in ores of the oxidized zone (Bastin and Hill, 1917).

Secondary silver enrichment occurred mostly in the galena-sphalerite ores at or below the level of the water 
table. Enrichment may extend 100-200 feet below groundwater level with silver concentrations decreasing with increasing depth. In the oxidized zone above the water table the ores were somewhat depleted in silver. The silver was deposited mostly as proustite $\left(\mathrm{Ag}_{3} \mathrm{AsS}_{3}\right)$-rarely as native silver.

Copper enrichment was confined entirely to the ground-water zone of the pyritic ores (Bastin and Hill, 1917). Ores in the oxidized zone were somewhat depleted in copper. The principle secondary copper mineral formed beneath the water table is chalcocite $\left(\mathrm{Cu}_{2} \mathrm{~S}\right)$.

\section{THE ARGO AND BIG FIVE TUNNELS}

The hills around Idaho Springs and Central City are honey-combed with adits, shafts, and tunnels. Most are longabandoned because of the low quality of the remaining ores. Two of these tunnels are the focus of this field trip-the Argo and the Big Five (fig. 15).

The Argo Tunnel (or Newhouse Tunnel) was designed to intersect at depth many of the veins that outcropped on the surface (Bastin and Hill, 1917), to drain the Central City mine workings, and to provide an easier and cheaper way to

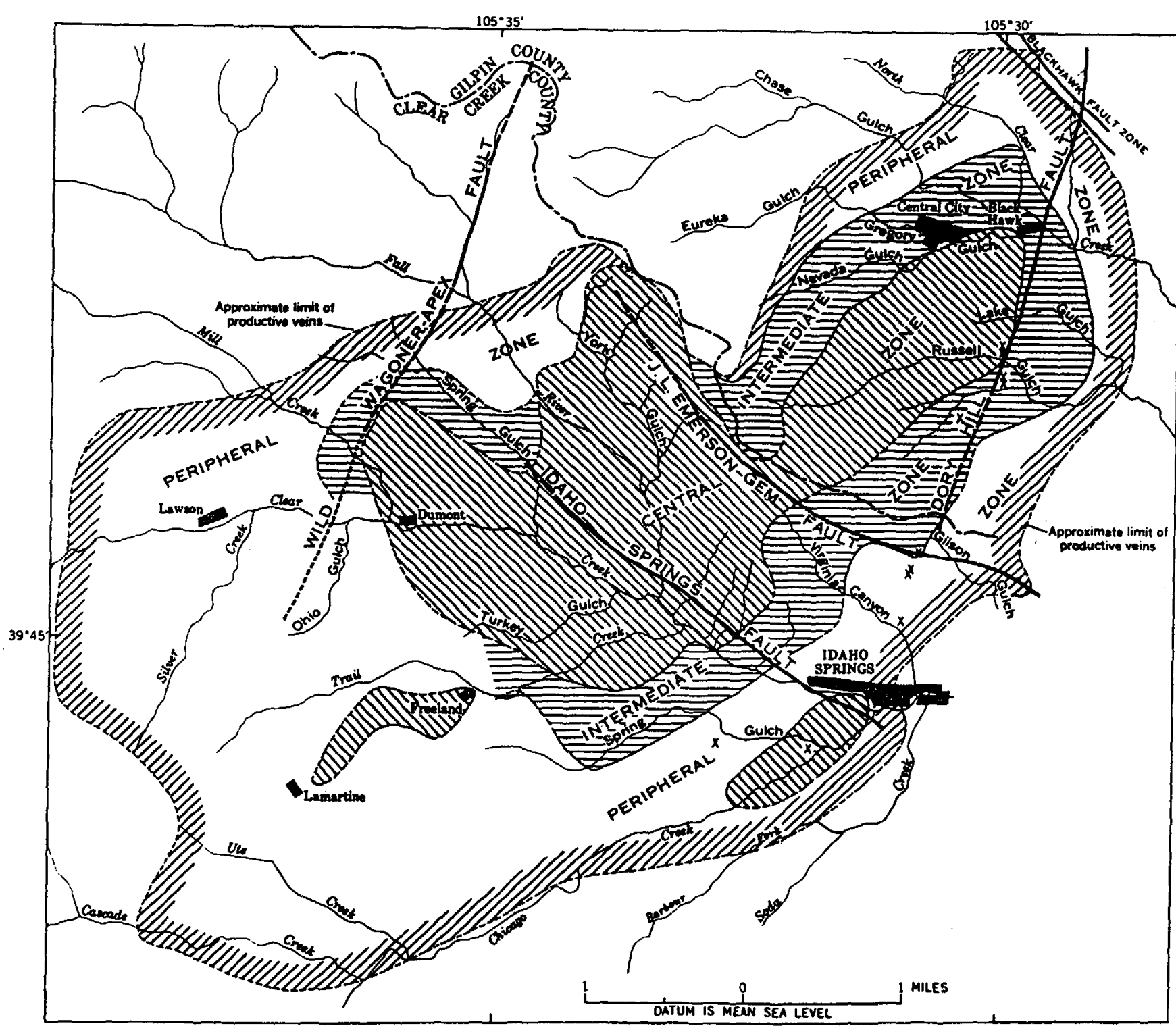

Figure 26. Map outlining principal zones of ore mineralization according to Sims (1989). Ore veins are classificd based on their content of base metals (lead, zinc, and copper). The central zone contains pyrite veins without base metals that grade into veins with abundant copper minerals. Veins of the intermediate zonc contain more lead and zinc and less copper. The peripheral zone contains mostly lead and zinc sulfides without pyrite. Gold and silver are most abundant in veins of the core and intermediate zones (adapted from Sims, 1989). 
transport ores to the mills. Most veins were of low grade where they were cut by the tunnel, although several profitable ones were found. The feeling persists today that the tunnel proved the deep veins were of poor quality and disappointing grade (Lovering and Goddard, 1950). The Argo Tunnel cuts schist of the Idaho Springs Formation, Precambrian granite gneiss, and Tertiary bostonite and monzonite ${ }^{30}$ porphyry ${ }^{31}$ dikes. The Argo also intercepts veins of pyritic, galena-sphalerite, composite, and telluride ores. According to the zonal configuration of Sims and others (1963), the tunnel cuts both the pyrite-rich central zone and the basemetal-rich intermediate zones.

The Big Five Tunnel cuts mostly schist of the Idaho Springs Formation, and some granite pegmatite and dikes of monzonite and bostonite. Most mineralization contains small amounts of finely disseminated pyrite or quartz, galena, and sphalerite. The tunnel cuts the Shafter vein with abundant composite ores, and the Bellman and Lake veins with abundant pyritic ores. Quartz and sericite ${ }^{32}$ are common alteration minerals found in the wall rocks (Idaho Springs schist). Quartz, pyrite, galena, sphalerite, chalcopyrite, tennantite, and various carbonate minerals are common in these veins. The tunnel cut ores of the peripheral, interme-

\footnotetext{
${ }^{30}$ Bostonite and monzonite are both types of igneous rocks formed below the Earth's surface. They differ from each other in their grain sizes and feldspar contents.

${ }^{31}$ Igneous rock with larger crystals set in smaller groundmass.

${ }^{32} \mathrm{~A}$ white, fine-grained, high-potassium mica occurring in small scales and flakes.
}

diate, and central zones as described by Sims and others (1963).

\section{REFERENCES}

Bastin, Edson S., and Hill, James M., 1917, Economic geology of Gilpin County and adjacent part of Clear Creek and Boulder Counties, Colorado: U.S. Geological Survey Professional Papcr 94, 379 p.

Lovering, T.S., and Goddard, E.N., 1950, Geology and ore deposits of the Front Range, Colorado: U.S. Geological Survey Professional Paper 223, 319 p.

Sims, Paul K., 1960, Geology of Central City-Idaho Springs area, Front Range, Colorado, in Weimer, Robert J., and Haun, John D., eds., Guide to the Geology of Colorado: Denver, Geological Society of America, Rocky Mountain Association of Geologists, and the Colorado Scientific Society, p. 279-285.

Sims, P.K., 1989, Central City and Idaho Springs Districts, Front Range, Colorado, in Bryant, Bruce, Beaty, David W., Mineral deposits and geology of Central Colorado: 28th International Geological Congress, Field Trip Guidebook T129, p. 15-19.

Sims, P.K. and Barton, P.B., 1962, Hypogene zoning and ore genesis, Central City District, Colorado, in Engel, A.E., James, H.L., and Leonard, B.F., eds., Petrologic studies; Buddington volume: Boulder, Colorado, Geological Society of America, p. 373-395.

Sims, P.K., Drake, A.A., Jr., and Tooker, E.W., 1963, Economic geology of the Central City District, Gilpin County, Colorado: U.S. Geological Survey Professional Paper 359, 231 p.
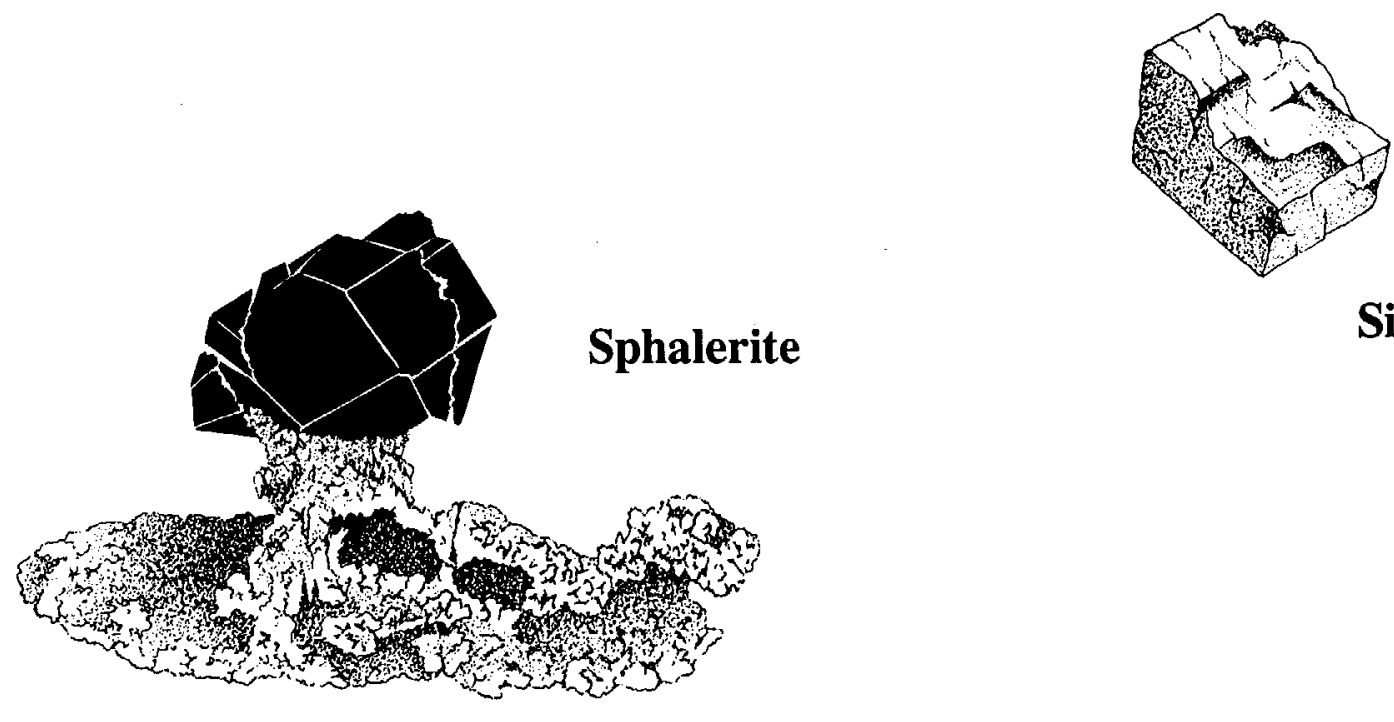

Siderite 


\title{
GENERATION AND INTERACTIONS OF MINE DRAINAGE AT THE ARGO TUNNEL
}

\author{
By Kathleen S. Smith
}

The ores of many mining districts, such as those around Idaho Springs, contain abundant sulfide (sulfur-bearing) minerals. When mining exposes these minerals to water, dissolved oxygen, and ferric $\left(\mathrm{Fe}^{3+}\right.$ ) iron, chemical reactions take place that can produce high concentrations of dissolved metals (such as zinc, copper, and lead), ferrous $\left(\mathrm{Fe}^{2+}\right.$ ) iron, sulfate, and acid $\left(\mathrm{H}^{+}\right)$(fig. 27, reaction $\mathrm{A}$ ). Certain kinds of bacteria catalyze (and increase the rate of) these reactions. The acid produced can attack other minerals in surrounding rocks and dissolve elements, such as calcium, aluminum, silicon, and manganese. Water involved in these reactions can become more acidic than vinegar (acetic acid) or lemon juice (citric acid) ( $\mathrm{pH}<4)$. After migration, further reactions may form iron-rich precipitates and more acid (fig. 27, reaction B). A more detailed discussion of the generation and interactions of mine drainage is given in the following sections.

\section{GENERATION OF MINE DRAINAGE}

Although the solubility of sulfide minerals in water is generally low, they are unstable in the presence of dissolved oxygen and/or ferric iron. Both dissolved oxygen and ferric iron can oxidize sulfide minerals, such as pyrite (also known as fool's gold), as illustrated in the following reactions:

$$
\begin{gathered}
\mathrm{FeS}_{2(\mathrm{~s})}+3.5 \mathrm{O}_{2(\mathrm{aq})}+\mathrm{H}_{2} \mathrm{O} \rightarrow \mathrm{Fe}^{2+}+2 \mathrm{SO}_{4}{ }^{2-}+2 \mathrm{H}^{+} \\
\mathrm{FeS}_{2(\mathrm{~s})}+14 \mathrm{Fe}^{3+}+8 \mathrm{H}_{2} \mathrm{O} \rightarrow 15 \mathrm{Fe}^{2+}+2 \mathrm{SO}_{4}{ }^{2-}+16 \mathrm{H}^{+}
\end{gathered}
$$

where $\mathrm{FeS} 2(\mathrm{~s})$ is pyrite, $\mathrm{O}_{2(\mathrm{aq})}$ is dissolved oxygen, $\mathrm{H}_{2} \mathrm{O}$ is water, $\mathrm{Fe}^{2+}$ is dissolved ferrous iron, $\mathrm{SO}_{4}{ }^{2-}$ is dissolved sulfate, $\mathrm{H}^{+}$is dissolved proton (responsible for acidity), and $\mathrm{Fe}^{3+}$ is dissolved ferric iron (Garrels and Thompson, 1960). In the $\mathrm{pH}$ range from 2 to 7 , pyrite oxidation is favored by reaction 2 rather than reaction 1 (Moses and others, 1987; Moses and Herman, 1991). Note that eight times more acidity is produced when ferric iron oxidizes pyrite (reaction 2) than when dissolved oxygen serves as the oxidant (reaction 1) (16 moles compared to 2 moles of $\mathrm{H}^{+}$per mole of $\mathrm{FeS}_{2(\mathrm{~s})}$ ). When ferric iron is the oxidant (reaction 2), the role of dissolved oxygen in the system appears to be limited to the replenishment of ferric iron by the following reaction:

$$
\mathrm{Fe}^{2+}+0.25 \mathrm{O}_{2(\mathrm{aq})}+\mathrm{H}^{+} \rightarrow \mathrm{Fe}^{3+}+0.5 \mathrm{H}_{2} \mathrm{O}
$$

This reaction is the rate-limiting step in the generation of mine drainage in the $\mathrm{pH}$ range from 2 to 9 (Moses and others, 1987; Moses and Herman, 1991).

Certain kinds of bacteria, called Thiobacillus and Leptospirillum, are able to derive energy from the conversion of ferrous to ferric iron (Harrison, 1984). Reaction 3 proceeds slowly at $\mathrm{pH}$ values $<4$. However, in the presence of these bacteria, conversion of ferrous to ferric iron (reaction 3 ) can proceed a million times faster than in the absence of bacteria (Singer and Stumm, 1970). These bacteria can thrive in environments where mining has taken place as long as a minimal amount of oxygen is present. Therefore, the production of mine drainage can be a rapid, self-propagating process that continues as long as oxygen, water, and pyrite are available (Nordstrom and others, 1979). Several other factors can affect the oxidation rate; these include surface area of the sulfide minerals, type and composition of the sulfide minerals, the presence of acid-neutralizing minerals (especially calcite and dolomite), and temperature and salinity of the ground water.

The following diagram summarizes the chemical and biological factors involved in the self-propagating generation of mine drainage from pyrite oxidation.

replenished by bacteria

(in the presence of oxygen)

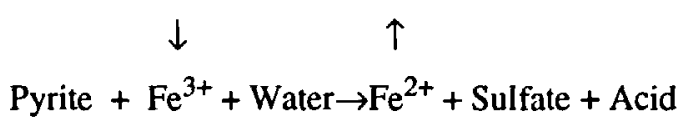

Dissolved oxygen and ferric iron can oxidize sulfide minerals that contain metals other than iron. In mines drained by the Argo Tunnel, oxidation of sphalerite ( $\mathrm{ZnS}$ ), chalcopyrite $\left(\mathrm{CuFeS}_{2}\right)$, and galena $(\mathrm{PbS})$ releases zinc $(\mathrm{Zn})$, copper $(\mathrm{Cu})$, and lead $(\mathrm{Pb})$ into the water.

The acid produced by some of the oxidation reactions discussed here can also attack minerals of surrounding rocks and dissolve their constituents. In the Argo Tunnel area, minerals in the rocks contain primarily aluminum, silicon, calcium, potassium, and manganese. Drainage from the tunnel, therefore, also contains elevated concentrations of these elements.

A more general term commonly used for the reactions discussed in this section is "rock drainage." 


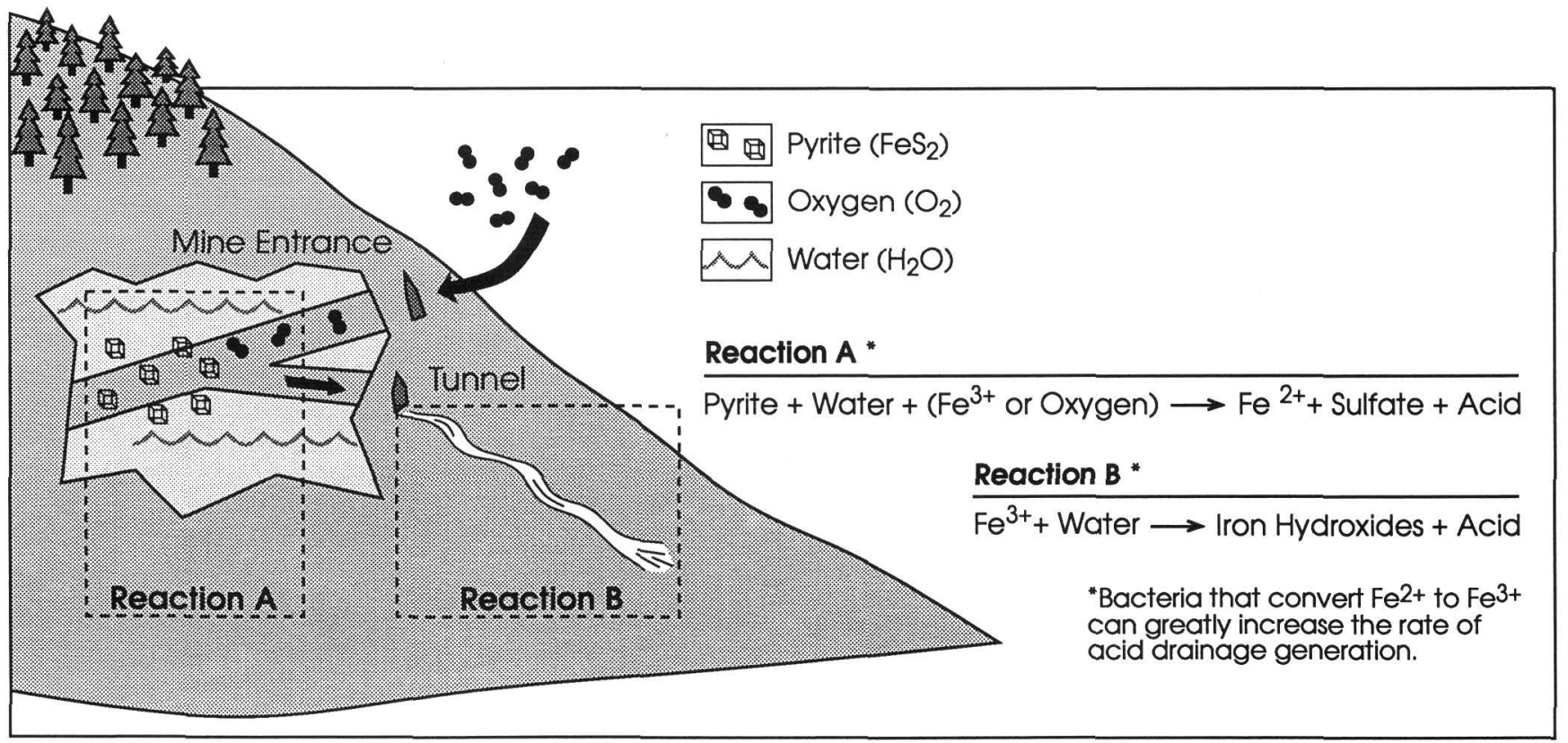

Figure 27. Diagrammatic representation of mine drainage reactions. Reactions begin as a result of mineral exposure to water and dissolved oxygen (diagram by Shawn Smith).

\section{INTERACTION OF MINE DRAINAGE DURING MIGRATION}

When mine-drainage waters migrate away from their site of generation, further reactions can take place. Moderate to highly acidic waters continue to dissolve constituents from most materials with which they make contact, thereby increasing the dissolved concentration of some elements. The dissolved concentration of other elements, however, decreases. For example, waters carrying elevated concentrations of iron frequently form iron-rich precipitates upon exposure to oxygen, or in response to a change in temperature, water chemistry, or increase in $\mathrm{pH}$ (Nordstrom, 1982). The following reactions demonstrate the formation of solid iron hydroxide from dissolved iron:

$$
\begin{gathered}
\mathrm{Fe}^{3+}+3 \mathrm{H}_{2} \mathrm{O} \rightarrow \mathrm{Fe}(\mathrm{OH})_{3(\mathrm{~s})}+3 \mathrm{H}^{+} \\
\mathrm{Fe}^{2+}+2.5 \mathrm{H}_{2} \mathrm{O}+0.25 \mathrm{O}_{2(\mathrm{aq})} \rightarrow \mathrm{Fe}(\mathrm{OH})_{3(\mathrm{~s})}+2 \mathrm{H}^{+}
\end{gathered}
$$

where $\mathrm{Fe}(\mathrm{OH})_{3(\mathrm{~s})}$ is solid iron hydroxide. Note that reactions 4 and 5 produce acidity. The precipitates may also sequester dissolved metals (such as copper) as they form.

In acidic drainages, such as that from the Argo Tunnel, iron-rich precipitates form red-orange-yellow coatings on the stream bottom and on the surface of bacteria, algae, and moss that live in the mine-drainage waters. The organisms here form long streamers on the bottom. It is thought that the precipitates are made up of a mixture of iron, hydroxide, oxygen, and sulfate. Geochemists call these precipitates "hydrous ferric oxides" or "ferric oxyhydroxysulfate" or "ferrihydrite" (Bigham and others, 1990); miners called them "yellow boy."

When relatively uncontaminated waters mix with and dilute mine-drainage waters changes take place. Some elements precipitate, some are sequestered by particulates in the water or on the stream bottom, and some remain dissolved. Where the Argo Tunnel drainage flows into Clear Creek, iron-rich precipitates (red-orange) form just downstream from the inflow. Manganese-rich precipitates (black) can often be observed a bit farther downstream (100 to $200 \mathrm{~m}$ ). Such elements and precipitates introduced into streams and rivers from mine drainage can adversely affect the quality, ecology, and chemistry of the receiving waters for many kilometers downstream (Moore and Luoma, 1990; Ficklin and Smith, 1993, this Circular).

\section{REFERENCES}

Bigham, J.M., Schwertmann, U., Carlson, L., and Murad, E., 1990, A poorly crystallized oxyhydroxysulfate of iron formed by bacterial oxidation of $\mathrm{Fe}$ (II) in acid mine waters: Geochimica et Cosmochimica Acta, v. 54, p. 2743-2758.

Ficklin, W.H., and Smith, K.S., 1993, Influence of mine drainage on Clear Creek, Colorado: U.S. Geological Survey Circular 1097, p. 43-48.

Garrels, R.M., and Thompson, M.E., 1960, Oxidation of pyrite in ferric sulfate solution: American Journal of Science, v. 258, p. 57-67. 
Harrison, A.P., Jr., 1984, The acidophilic thiobacilli and other acidophilic bacteria that share their habitat: Annual Reviews in Microbiology, v. 38, p. 265-292.

Moore, J.N., and Luoma, S.N., 1990, Hazardous wastes from largescale metal extraction-A case study: Environmental Science and Technology, v. 24, p. 1278-1285.

Moses, C.O., and Herman, J.S., 1991, Pyrite oxidation at circumneutral pH: Geochimica et Cosmochimica Acta, v. 55, p. $471-482$.

Moses, C.O., Nordstrom, D.K., Herman, J.S., and Mills, A.L., 1987, Aqueous pyrite oxidation by dissolved oxygen and by ferric iron: Geochimica et Cosmochimica Acta, v. 51, p. $1561-1571$.
Nordstrom, D.K., 1982, Aqueous pyrite oxidation and the consequent formation of secondary iron minerals, in J.A. Kittrick, D.S. Fanning, L.R. Hossner, eds., Acid Sulfate Weathering, SSSA Special Publication Number 10: Madison, Wisconsin, Soil Science Society of America, p. 37-56.

Nordstrom, D.K., Jenne, E.A., and Ball, J.W., 1979, Redox equilibria of iron in acid mine waters, in E.A. Jenne, ed., Chemical Modeling in Aqueous Systems-Speciation, Sorption, Solubility, and Kinetics, ACS Symposium Series 93: Washington, D.C., American Chemical Society, p. 51-79.

Singer, P.C., and Stumm, W., 1970, Acid mine drainage-The rate determining step: Science, v. 167, p. 1121-1123.

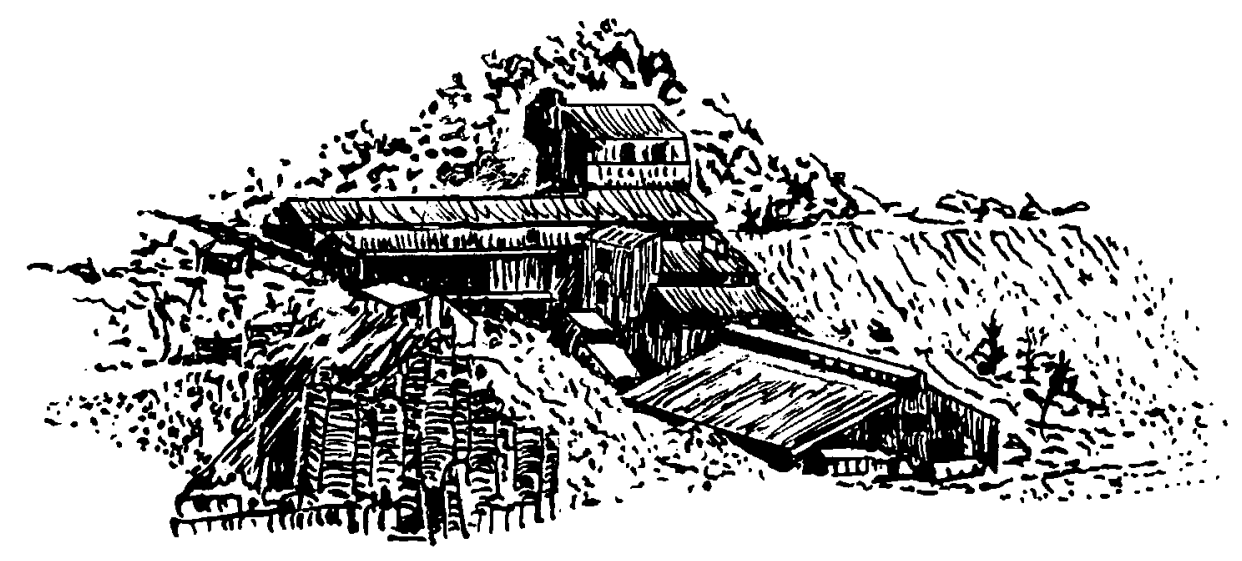

Argo Mill 

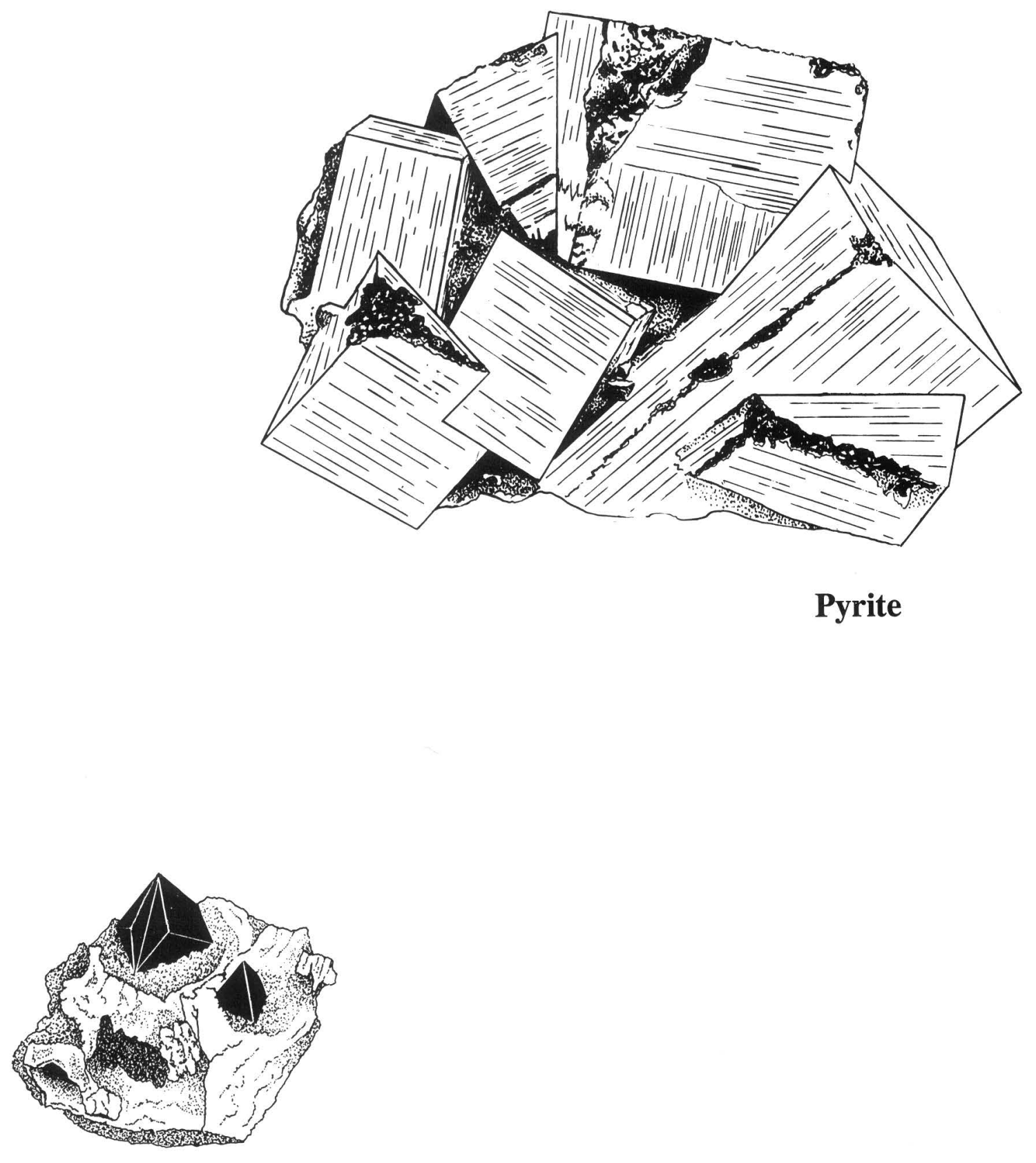

Tetrahedrite

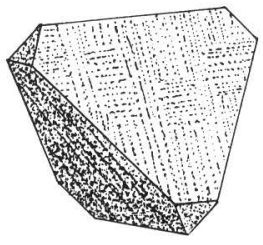

\section{Chalcopyrite}




\title{
INFLUENCE OF MINE DRAINAGE ON CLEAR CREEK, COLORADO
}

\author{
By Walter H. Ficklin ${ }^{\dagger}$ and Kathleen S. Smith
}

Mine drainage is a serious environmental problem in Colorado. The State of Colorado has determined that over 1,300 miles of its streams are impacted by metals as a result of drainage from mining areas. This mine drainage is often acidic and generally contains high concentrations of dissolved metals and metalloids. These high concentrations are caused both by the oxidation of metallic sulfides and by the acid dissolution of the country rock (see Smith, this Circular, p. 39). Oxidation of metallic sulfides can cause elevated concentrations of elements, such as iron ( $\mathrm{Fe})$, zinc $(\mathrm{Zn})$, copper $(\mathrm{Cu})$, lead $(\mathrm{Pb})$, cadmium $(\mathrm{Cd})$ and arsenic (As). Acid dissolution of the country rock can result in the release of the following elements: aluminum (Al), manganese $(\mathrm{Mn})$, silicon $(\mathrm{Si})$, calcium $(\mathrm{Ca})$, magnesium $(\mathrm{Mg})$, sodium $(\mathrm{Na})$, and potassium (K).

Additional information on the extent of contamination due to mine drainage in Colorado can be found in Wentz (1974). Kimball and Wetherbee (1988) reported on the instream chemical reactions of acidic mine water entering a neutral stream. A very technical discussion of the chemistry of natural waters can be found in Stumm and Morgan (1981). Ferguson and Gavis (1972) discussed the chemistry of arsenic in natural waters. Benjamin and Leckie (1981) discussed $\mathrm{pH}$-dependent adsorption of metals on hydrous iron oxide.

\section{CHARACTERIZATION OF WATER QUALITY IN CLEAR CREEK}

Amazingly, 13 different streams in Colorado are called Clear Creek. The particular Clear Creek that we are interested in originates at the Continental Divide west of Georgetown, Colorado, in the pristine alpine environment found at 11,000 feet of elevation near Torreys Peak (fig. 28). Along its path through the Front Range of the Rocky Mountains, Clear Creek traverses a section of the Colorado Mineral Belt. Many old mines and mine dumps can be seen along Interstate Highway 70, which follows the course of Clear Creek throughout most of Clear Creek County, Colorado. Eventually, Clear Creek empties into the South Platte River just north of Denver (fig. 1). During periods of low flow most of

\footnotetext{
$\dagger_{J a n u a r y} 13,1937$ to October 11, 1993.
}

the water is removed from the stream at Golden, Colorado, for domestic, agricultural, and industrial use.

Acidic metal-rich drainage from the Argo Tunnel in the City of Idaho Springs (fig. 29) enters Clear Creek and has a profound effect on the concentration of dissolved constituents, the amount of suspended sediment, and the concentration of metals in the streambed sediment. The concentration of several constituents found in the Argo Tunnel water is presented in table 2. The South Fork of Clear Creek receives waters draining the Argentine Mining District near the city of Georgetown. The West Fork of Clear Creek receives mine drainage from an area near the town of Empire. The North Fork of Clear Creek (North Clear Creek) passes through the Central City Mining District (figs. 1 and 29). The waters and sediments of the North Fork are particularly affected by mining and add additional metals to Clear Creek.

In June of 1986, during high flow, we collected 27 water and sediment samples from Clear Creek at about 2mile intervals from above Georgetown near Torreys Peak to its mouth on the South Platte River. Sample locations are shown in figure 29. The distribution of samples covered almost the entire length of the stream. In October of that same year, when low flow was re-established, we collected samples at the same locations (fig. 30). Field observations included $\mathrm{pH}$, temperature, and conductivity.

Metals and metalloids are transported in streams and rivers both as dissolved constituents and as suspended sediment. For this study, dissolved metal concentrations were determined from samples filtered through a 0.45 -micrometer filter (fig. 31); total metal concentrations were determined from unfiltered samples. Both filtered and unfiltered samples were acidified. The amount of an element carried in the suspended phase was calculated from the difference between concentrations in the unfiltered (total concentration) water and the filtered (dissolved concentration) water.

Graphical results for dissolved and total concentrations of iron, manganese, copper, and zinc are presented in figure 32 for June 1986 and in figure 33 for October 1986. The results demonstrate the addition of iron, manganese, copper, and zinc to the stream system by the acidic metal-rich water of the Argo Tunnel. Elevated concentrations of these metals are transported by Clear Creek to its confluence with the South Platte River, especially during high flow. The graphs also show the partitioning of these metals between the 


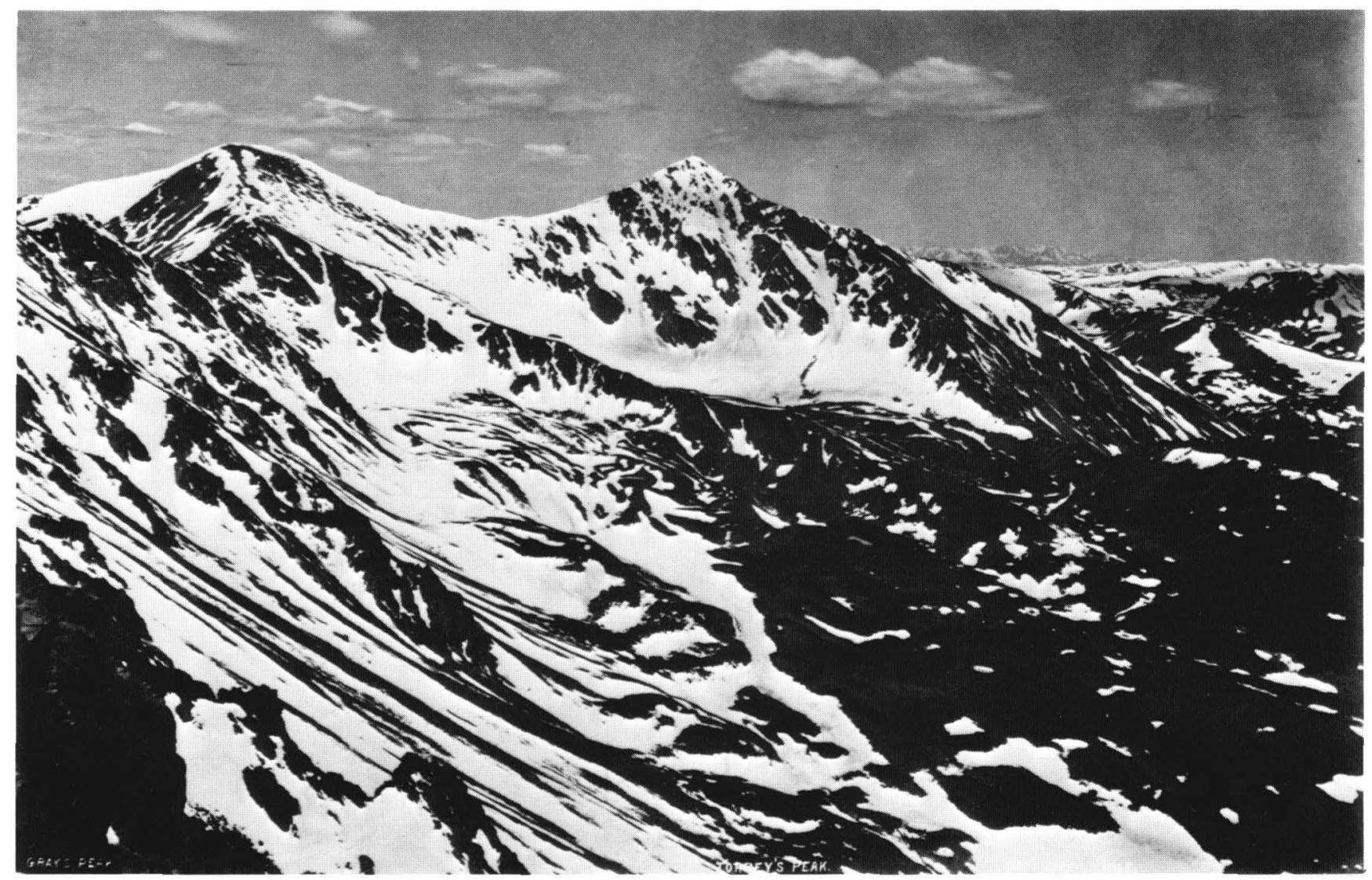

Figure 28. View of Torreys Peak looking toward the west. Peaks of the Continental Divide are visible behind it on the horizon. Clear Creek is out of view to the right. (U.S. Geological Survey photograph by W. H. Jackson, 1873.)

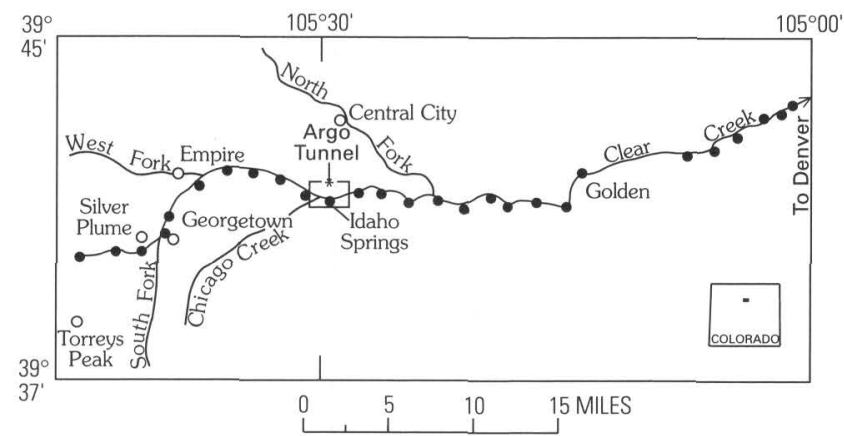

Figure 29. Location of sample collection sites along Clear Creek. Samples were taken from near the Continental Divide to within 3 miles of its confluence with the South Platte River. 


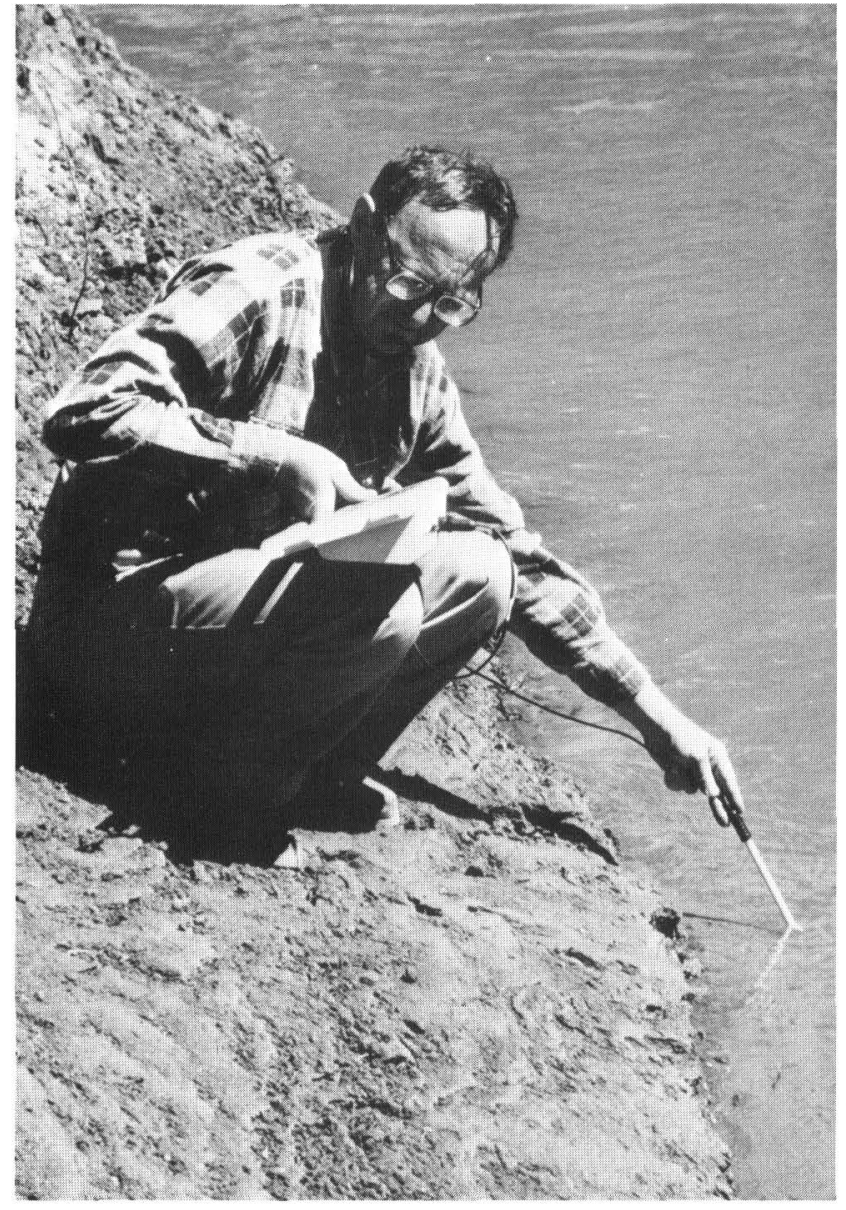

Figure 30. U.S. Geological Survey research chemist Walter H. Ficklin measuring $\mathrm{pH}$ with a portable meter. Walt died suddenly on October 11, 1993, after 25 years with the U.S. Geological Survey (photograph by Larry P. Gough).

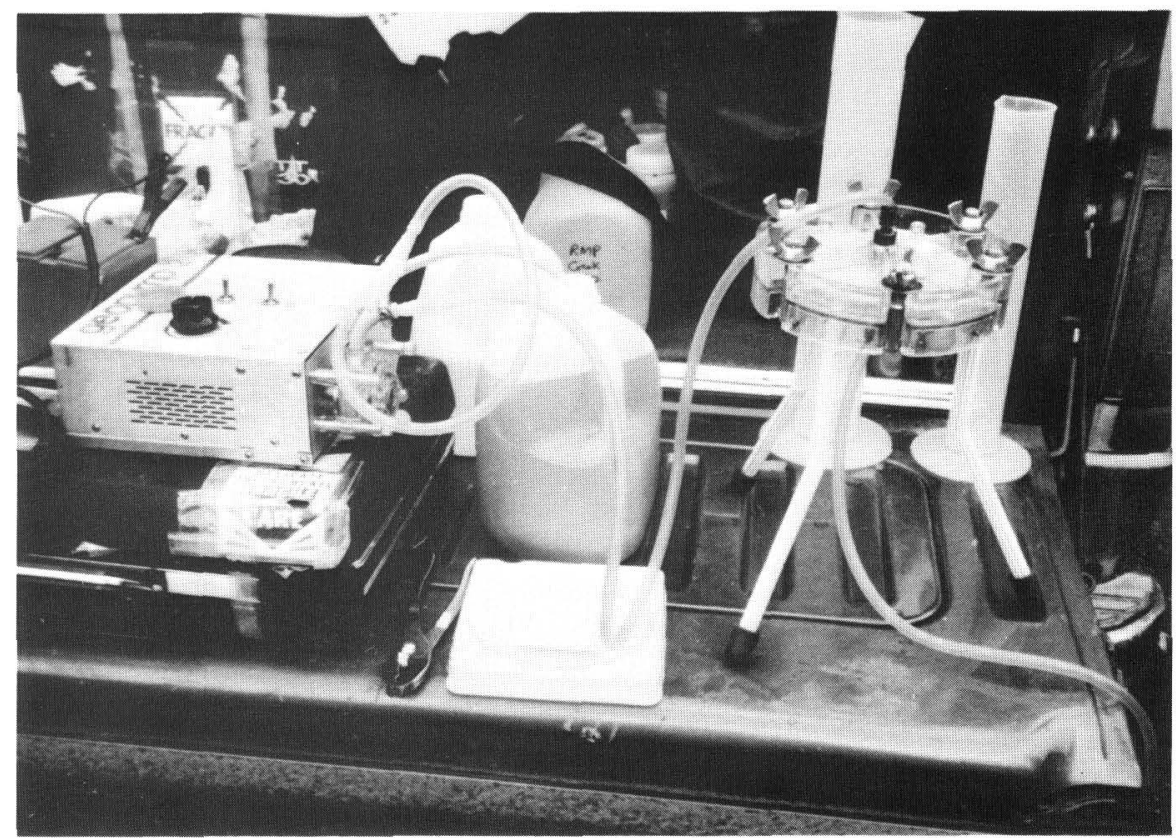

Figure 31. Typical filter apparatus for water samples. Raw water sample from jug passes through filter held in tripod-like structure and is collected in bottles (photograph by Geoffrey S. Plumlee). 

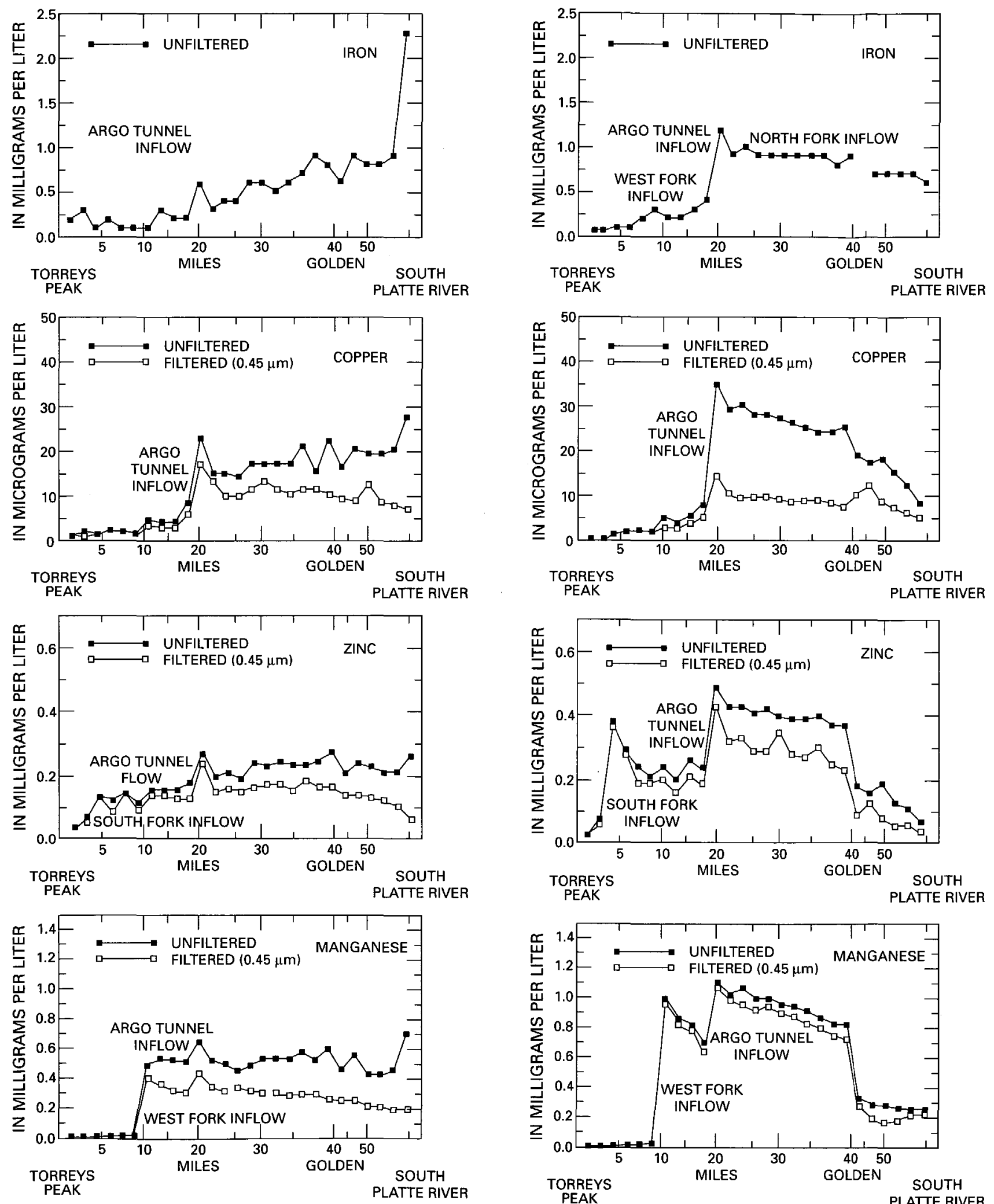

Figure 32. Influence of various inflows on the dissolved (passed through $0.45 \mu \mathrm{m}$ filter) and total (unfiltered) concentrations of iron, manganese, copper, and zinc in water collected from Clear Creek in June 1986. Dissolved concentrations of iron were below the determination limit of $0.1 \mathrm{mg} / \mathrm{L}$ and are not shown in the graph. $\mu \mathrm{m}=$ micrometer; $\mathrm{mg} / \mathrm{L}=$ milligrams per liter (roughly equivalent to parts per million).

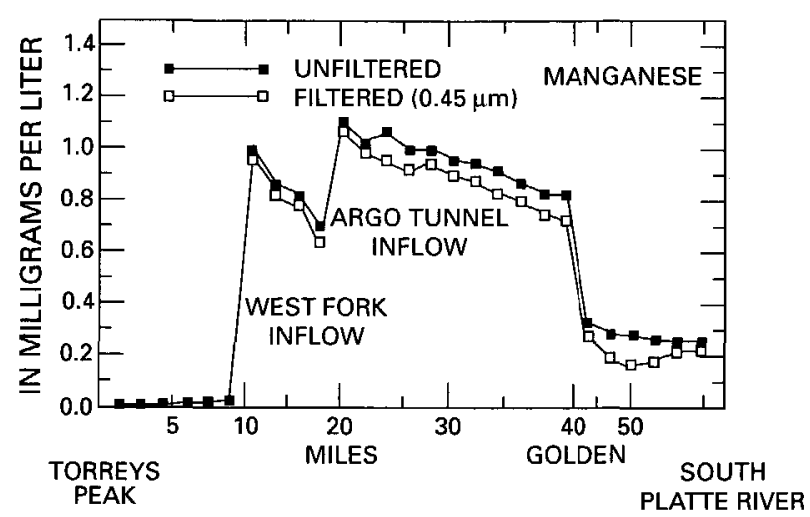

Figure 33. Influence of various inflows on the dissolved (passed through $0.45 \mu \mathrm{m}$ filter) and total (unfiltered) concentrations of iron, mangancse, copper, and zinc in water collected from Clear Creek in October 1986. Dissolved concentrations of iron were below the determination limit of $0.1 \mathrm{mg} / \mathrm{L}$ and are not shown in the graph. Scc figure 32 and table 2 for definitions of various units. 
Table 2. Dissolved constituents in Argo Tunnel water, August 1985, and Clear Creek, October 1985.

\begin{tabular}{lrrr}
$\begin{array}{l}\text { Constituent, } \\
\text { concentration }\end{array}$ & $\begin{array}{c}\text { Argo Tunnel } \\
\text { water }\end{array}$ & Clear Creek at Argo Tunnel \\
& & Upstream & Downstream \\
\hline Sulfate, $\mu \mathrm{g} / \mathrm{L}^{1}$ & $2,000,000$ & 29,000 & 44,000 \\
Calcium, $\mu \mathrm{g} / \mathrm{L}$ & 400,000 & 14,000 & 15,000 \\
Magnesium, $\mu \mathrm{g} / \mathrm{L}$ & 110,000 & 3,000 & 3,300 \\
Iron, $\mu \mathrm{g} / \mathrm{L}$ & 37,000 & $<100$ & $<100$ \\
Manganese, $\mu \mathrm{g} / \mathrm{L}$ & 31,000 & 640 & 1,100 \\
Sodium, $\mu \mathrm{g} / \mathrm{L}$ & 19,000 & 8,300 & 8,700 \\
Zinc, $\mu \mathrm{g} / \mathrm{L}$ & 9,600 & 190 & 430 \\
Copper, $\mu \mathrm{g} / \mathrm{L}$ & 5,400 & 18 & 14 \\
Potassium, $\mu \mathrm{g} / \mathrm{L}$ & 4,000 & 1,700 & 1,700 \\
Molybdenum, $\mu \mathrm{g} / \mathrm{L}$ & 170 & no data & no data \\
Arsenic, $\mu \mathrm{g} / \mathrm{L}$ & 120 & $<1$ & $<1$ \\
pH, std. units & 3.2 & 7.5 & 7.6 \\
\hline
\end{tabular}

${ }^{1}$ Micrograms per liter (equivalent to parts per billion).

dissolved and suspended phases. In each case, part of the total concentration is accounted for by suspended materialthe difference between the unfiltered and filtered lines for a given element. Iron is present primarily in the suspended phase, and manganese, copper, and zinc are present in both dissolved and suspended phases. Note that much more manganese, copper, and zinc are present in the suspended phase downstream from the Argo Tunnel inflow. This indicates that reactions at the Argo Tunnel inflow cause metals to be partitioned to the suspended sediment phase.

\section{FACTORS INFLUENCING METAL TRANSPORT IN CLEAR CREEK}

Dissolved metal concentrations decrease in Clear Creek downstream from the Argo Tunnel inflow due to oxidation, precipitation, and adsorption reactions and due to dilution effects. (See "Generation and Interactions of Mine Drainage at the Argo Tunnel" by Smith, p. 39.) Many metals become adsorbed onto hydrous oxides of iron, aluminum, and manganese and are then transported with the oxides. The $\mathrm{pH}$ range for adsorption is different for each metal and each type of oxide. Adsorption of positively charged metal cations (such as copper and zinc) generally increases as the $\mathrm{pH}$ of the stream water increases. Figure 34 demonstrates that the proportion of copper and zinc associated with the suspended phase increases with increasing stream water $\mathrm{pH}$ in Clear Creek in June 1986 downstream from the Argo Tunnel. This indicates that both copper and zinc may be adsorbed onto hydrous oxides that precipitate when drainage from the Argo Tunnel enters Clear Creek. However, this pH-dependent partitioning to the suspended phase is not apparent in data from October 1986.

Argo Tunnel water also contributes dissolved arsenic to Clear Creek; but below the tunnel inflow, dissolved arsenic cannot be detected (table 2). Figure 35 shows that just downstream from the Argo Tunnel at least some of the arsenic becomes loosely bound (soluble in dilute hydrochloric acid) to streambed sediment. A similar increase in sediment-borne arsenic is seen at the confluence of the North Fork of Clear Creek with Clear Creek. Hydrous iron oxides associated with suspended material may transport arsenic as well.

\section{CONCLUSIONS}

Argo Tunnel water affects the quality of Clear Creek water from its inflow at Idaho Springs until its further dilution when it mixes with South Platte River water-a distance 

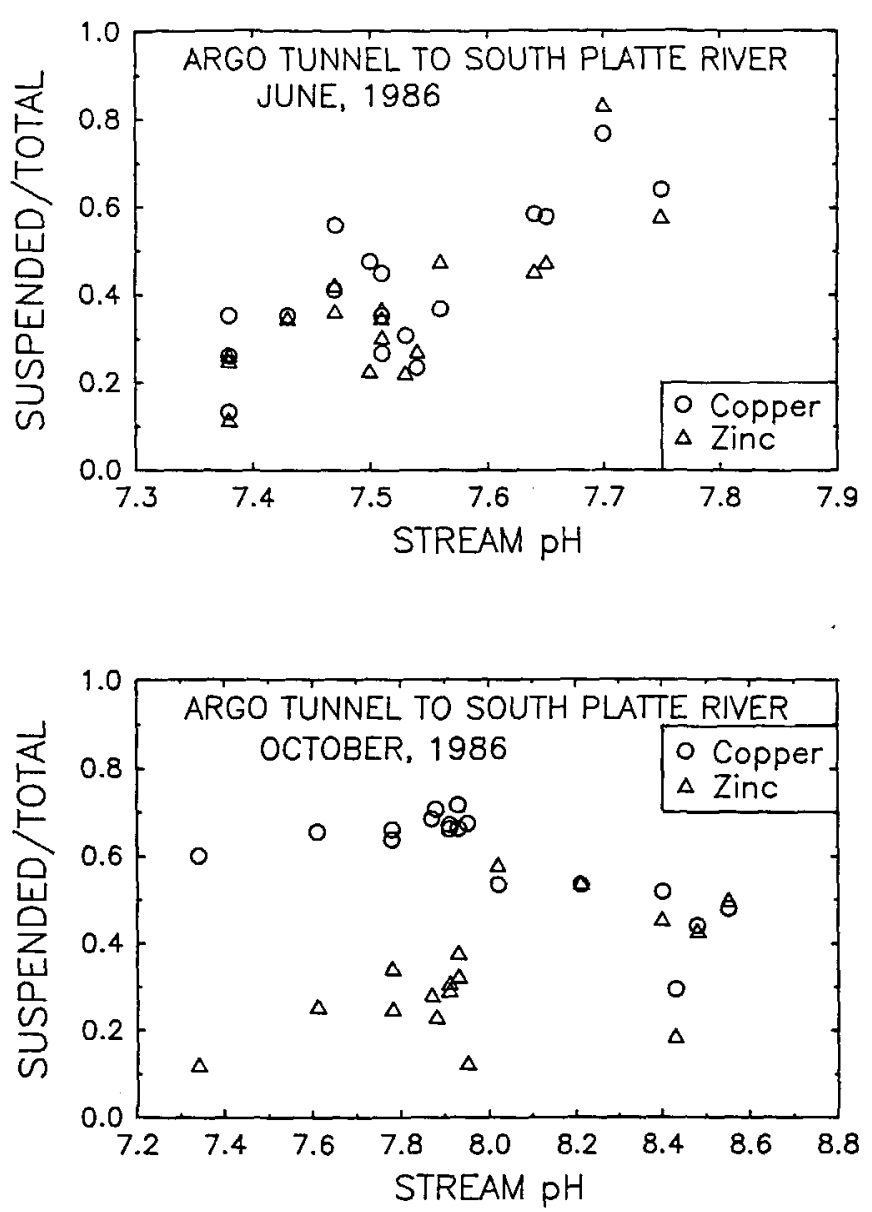

Figure 34. Proportion of suspended load of copper and zinc versus stream water $\mathrm{pH}$ downstream from the Argo Tunnel drainage into Clear Creek in June and October 1986.

of nearly 35 miles. Dissolved and suspended-sediment concentrations of iron, manganese, copper, and zinc increase due to the inflow of the Argo Tunnel. In Clear Creek, iron from the Argo Tunnel is transported primarily in the suspended phase; manganese, copper, and zinc are transported in both dissolved and suspended phases. Loosely bound arsenic appears to be associated with the streambed sediment along Clear Creek, showing a dramatic increase in concentration just downstream from confluences with the

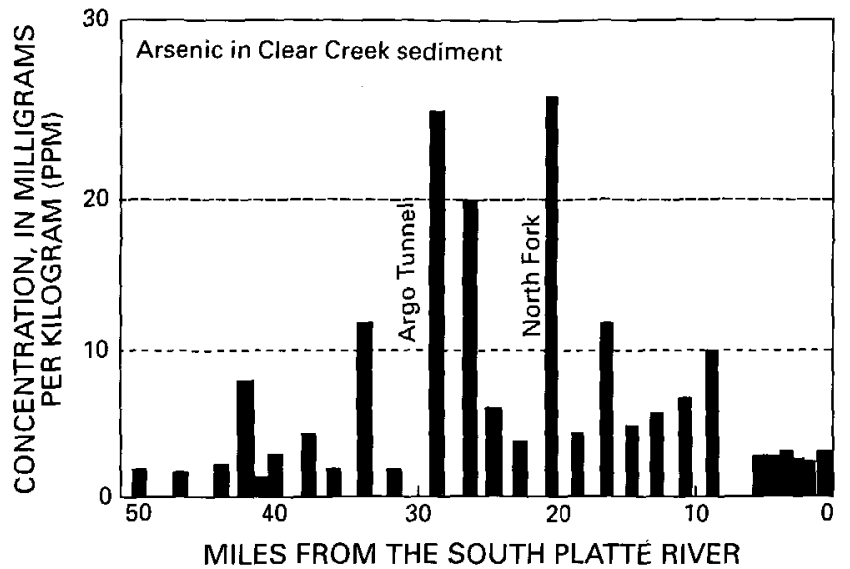

Figure 35. Distribution of loosely bound arsenic in Clear Creek sediment from near the Continental Divide to its confluence with the South Platte River.

Argo Tunnel drainage and with the North Fork of Clear Creek.

\section{REFERENCES}

Benjamin, M.M., and Leckie, J.O., 1981, Competitive adsorption of $\mathrm{Cd}, \mathrm{Cu}, \mathrm{Zn}$, and $\mathrm{Pb}$ on amorphous iron oxyhydroxide: Journal of Colloid and Interface Science, v. 83, p. 410-419.

Ferguson, J.F., and Gavis, Jerome, 1972, A review of the arsenic cycle in natural waters: Water Research, v. 6, p. 1259-1274.

Kimball, B.A., and Wetherbee, G.A., 1988, Instream chemical reactions of acid mine water entering a neutral stream near Leadville, Colorado, in G.E. Mallard and S.E. Ragone, eds., Proceedings of the Technical Meeting, Phoenix, Arizona, September 26-30, 1988, U.S. Geological Survey Toxic Substances Hydrology Program: U.S. Geological Survey Water Resources Investigations Report 88-4420, p. 567.

Smith, K.S., 1994, Generation and interactions of mine drainage at the Argo Tunnel: U.S. Geological Survey Circular 1097, p. 39-41.

Stumm, Werner, and Morgan, J.J., 1981, Aquatic Chemistry, 2nd Edition: New York, John Wiley and Sons, Inc., 780 p.

Wentz, D.A., 1974, Effect of mine drainage on the quality of streams in Colorado 1972-73: Colorado Water Resources Circular No. 21, Colorado Water Conservation Board, Denver, Colorado, $117 \mathrm{p}$. 


\title{
CONSTRUCTED WETLAND TREATMENT OF ACID MINE DISCHARGE AT IDAHO SPRINGS, COLORADO
}

\author{
By John C. Emerick, Thomas R. Wildeman, Ronald R. Cohen, and Ronald W. Klusman
}

\begin{abstract}
Acid mine drainage affects the water quality and aquatic resources of many streams and rivers in the mineral belt of the Southern Rocky Mountains. In an effort to develop low-cost effective methods to treat mine discharge using constructed wetlands, a pilot-scale treatment system has been maintained at the Big Five Tunnel in Idaho Springs, Colorado, since October 1987. This experimental system has been used to assess the importance of substrate type, flow characteristics, vegetation, and other factors on treatment effectiveness. During the life of the pilot system, modifications and additions have been made in an effort to refine knowledge of treatment processes and to develop design criteria for large-scale systems. This system has been effective for removal of most metals studied, including iron, zinc, and copper. In general, results indicate that treatment systems incorporating a mechanism to force vertical flow through the substrate are more effective than systems relying on lateral flow. Low flow rates provide more effective metal removal than high flow rates.
\end{abstract}

\section{INTRODUCTION}

Waters with low $\mathrm{pH}$ and high metal concentrations associated with drainage from mineralized zones have one of the most serious impacts on surface water in the Rocky Mountain region. These waters form as a result of geochemical processes involving the oxidation of metal sulfides found in mineralized rock. Reactions are initiated by exposure of the rock to moisture and oxygen. This occurs naturally in places where the host rock is fractured and results in so-called "iron seeps" or "iron bogs," whose presence has been used in geochemical exploration for minerals. Manmade situations cause greater concern. Where sulfide-bearing rock has been exposed in underground mine workings, or at the surface in mine dumps or mill tailings, the geochemical sulfide weathering processes have been accelerated. These conditions often promote the formation of acid drainage and acid leachate from surface waste piles. (See "Influence of Mine Drainage on Clear Creek, Colorado" by Ficklin and Smith, 1993, p. 43). In both cases, the major environmental concerns are to maintain the quality of the receiving waters for fisheries habitat, and to avoid potential threat to human populations.

State and federal agencies are particularly concerned with inactive mines because of the lack of adequate treatment, poor records of ownership, and the large numbers of these sites in western mineral belts. In Colorado, several mining districts have been placed on the National Priority List for action under the Comprehensive Environmental Response, Compensation, and Liability Act of 1980 (known as CERCLA or Superfund), including the Idarado Mine near Telluride, the Eagle Mine near Minturn, the California Gulch district near Leadville, and the Central City-Idaho Springs district.

These problems have highlighted the need for an effective and relatively inexpensive technology to treat acid mine drainage and acid leachate from surface waste piles. Although various methods of conventional treatment exist, such technologies have either a high equipment cost, a high maintenance cost, or both. For several years we have been examining the potential of using natural biogeochemical processes in a constructed wetland scheme to treat acid mine drainage. Coal mining regions of the Eastern United States have used this technology with some success, but its effectiveness for remediation of metal mine discharges in mountain climates has not been established with certainty.

In 1987, as part of the remedial investigation connected with the Central City-Idaho Springs Superfund Project, scientists constructed an experimental pilot-scale wetland to evaluate its effectiveness and to determine the most important biogeochemical processes involved in metal removal and remediation of acid conditions. The Environmental Protection Agency (EPA) initially funded the work through a subcontract with Camp, Dresser, and McKee, and later through the EPA's Emerging Technology Program. The experimental wetland was constructed at the portal of the Big Five Tunnel, at the western edge of Idaho Springs, Colorado.

This report summarizes results of some studies at the wetland and presents perspectives on the design of operational systems. It is not intended to provide a detailed description of methods, or even a synopsis of all the studies that have been conducted at the site; much of that information is available in a book by Wildeman and others (1992). Detailed discussions on the role of vascular plants and bacteria can be found in a book by Hammer (1989). Herlihy and 
Mills (1985) and Wakao and others (1979) address the role of bacteria in treatment of mine drainage. Also of special interest are reports by Kerndorf and Schnitzer (1980), who discuss metal sorption to humic acids, and by Benjamin and Leckie (1981), who discuss metal sorption to hydrous iron oxides.

\section{SITE CONDITIONS AND CONSTRUCTION OF THE ORIGINAL TREATMENT SYSTEM}

Excavation of the Big Five Tunnel began in December 1900 as a drainage tunnel for several gold and silver mines in the Idaho Springs district. The site is located in the valley bottom at an elevation of approximately $2,280 \mathrm{~m}(7,600 \mathrm{ft})$ and less than $100 \mathrm{~m}$ from Clear Creek. Because of its location, the climate is cool, and cold air drainage from the surrounding slopes can produce freezing conditions even during the summer. Water flow from the tunnel is relatively constant throughout the year, averaging $1.34 \mathrm{~L} / \mathrm{sec}^{33}$. The chemical characteristics also are relatively uniform over time. Table 3 shows mean concentrations for the more important metals in the drainage. Mean temperature is approximately $13^{\circ} \mathrm{C}$, and $\mathrm{pH}$ is usually about 2.6 . The major anion is sulfate, averaging $2,100 \mathrm{mg} / \mathrm{L}$.

Construction of the treatment system was completed in the fall of 1987 (fig. 36). In its original configuration, the system was $3.05 \mathrm{~m}$ ( $10 \mathrm{ft}$ ) wide by $18.3 \mathrm{~m}(60 \mathrm{ft})$ long, with a foundation constructed of concrete and wood to allow a

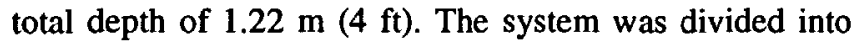
three equally sized cells, A, B, and C, each $6.1 \mathrm{~m}(20 \mathrm{ft})$ long. Each cell was lined with Hypalon, an acid-resistant liner fabric, to prevent leakage.

Several media were tried in the cells. Cell A was filled with mushroom compost consisting of approximately 50 percent animal manure and 50 percent barley mash wastes from a local brewery. Cells $B$ and $C$ were filled with a substrate consisting of equal parts of peat, aged steer manure, and decomposed wood shavings and sawdust. In addition to the above substrate, the bottom of cell $\mathrm{C}$ was filled to a depth of $12 \mathrm{~cm}(5 \mathrm{in})$ with limestone rock prior to laying the organic substrate. Following installation of the organic substrate, several species of aquatic plants were transplanted into each cell (fig. 37)—primarily cattail (Typha latifolia), sedges (Carex aquatilis and C. utriculata), and arctic rush (Juncus arcticus). These plants were obtained from nearby wetland areas and from Shadow Mountain Reservoir near Grand Lake, Colorado.

Flow into and through the cells was regulated by a system of polyvinyl chloride (PVC) pipe and valves. The pipes

\footnotetext{
${ }^{33}$ Liters per second, a liter of liquid is slightly more than a quart.
}

Table 3. Average concentrations and daily output (loading) for selected metals in the Big Five Tunnel effluent.

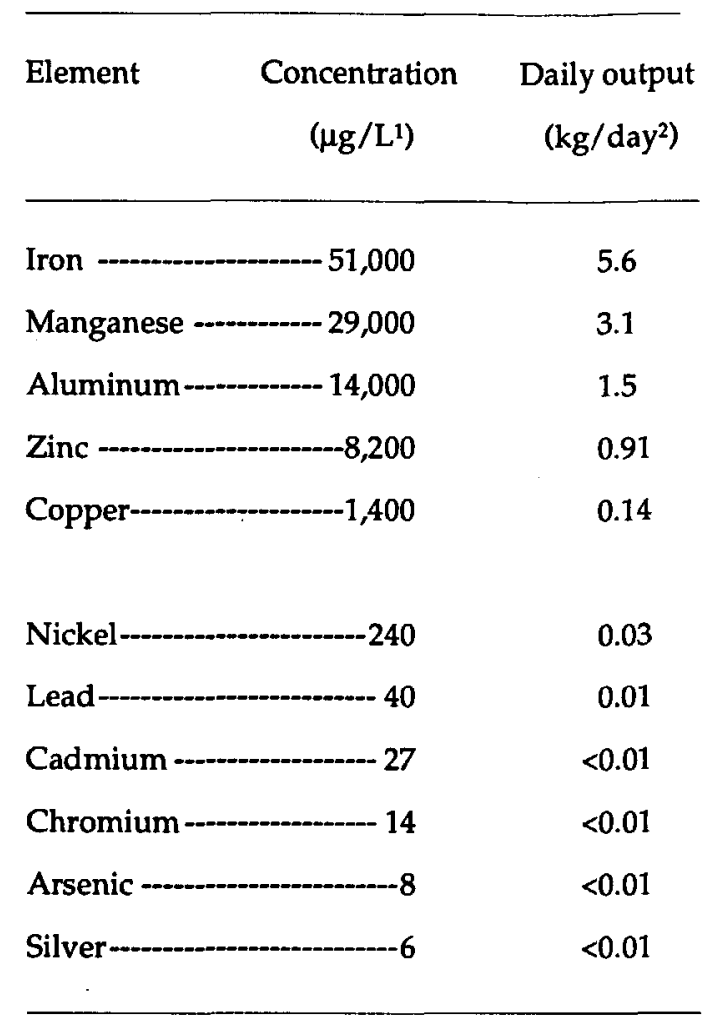

'Micrograms per liter (equivalent to parts per billion).

${ }^{2}$ Kilograms per day, a kilogram is about 2.2 pounds.

carried mine drainage from the portal to a $30-\mathrm{cm}$ (12-in) wide rock basket at the head of each cell. The basket extended across the entire width of the cell and was held in place with plastic fencing. This configuration allowed water to be distributed over the entire surface of the substrate and to flow laterally through the substrate toward the drain at the downstream end of each cell. Saturation of each cell was controlled by overflow into a standpipe attached to the drain. Water eventually percolated to the top of the substrate, where it was drawn off by the standpipe. A PVC drain pipe was installed at the downstream end of each cell. The initial flow rate of $3.8 \mathrm{~L} / \mathrm{min}$ ( $1 \mathrm{gal} / \mathrm{min}$ ) was selected according to guidelines published by the U.S. Bureau of Mines from similar investigations on treatment systems in eastern coal mining areas.

During most of the project, monthly samples of water, substrates, and plants were collected for analysis. Substrates and plants were analyzed for major cations and trace elements; water samples were analyzed for principal anions, cations, trace elements, and nutrients (phosphate and nitrate). 


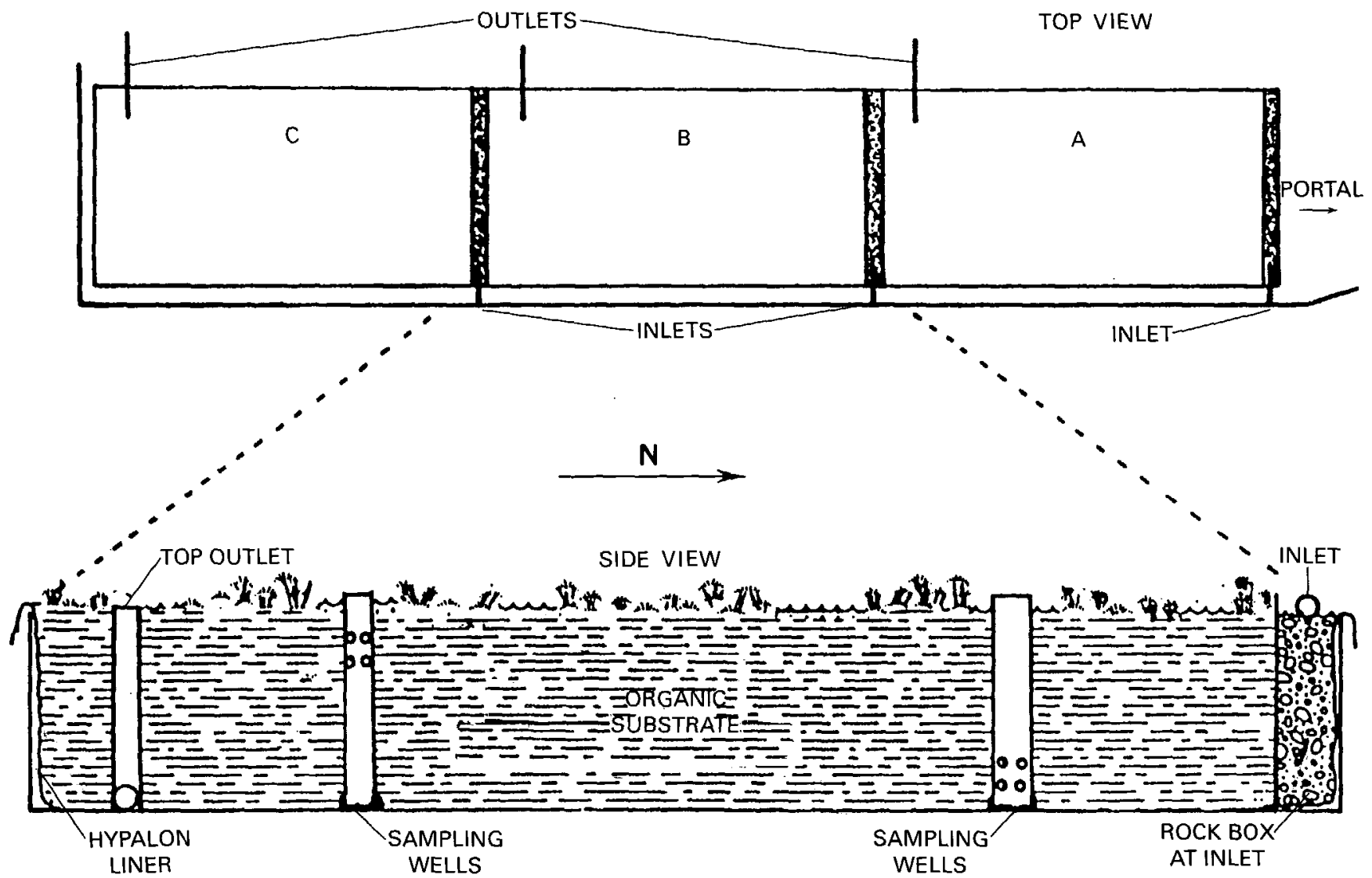

Figure 36. Plan view and cross section of the Big Five Tunnel constructed wetland looking west.

Several conclusions resulted from the first year of operation. First, we found an unacceptable degree of "shortcircuiting" and channelization taking place. This allowed the mine drainage to rise to the surface close to the rock box and flow over the top of the cell to the drain. Secondly, flow rates appeared to be too high for the cells. We therefore felt that the drainage had insufficient contact with the substrate and that more metal could be removed by the system.

\section{DESIGN MODIFICATIONS}

During 1988 and 1989, several changes were made. Cell A was rebuilt with a system of longitudinal walls to increase the flow path and with transverse redistribution baffles that were designed to collect water from the top surface and return it to the bottom (fig. 38).

Cell $\mathrm{B}$ was divided into two $3.05-\mathrm{m}$ by $3.05-\mathrm{m}$ (10-ft by $10-\mathrm{ft}$ ) cells that were redesigned to promote vertical flow (fig. 39). Each half of cell B was fitted with a perforated PVC distribution system at the top and at the bottom of each cell so that mine drainage could either be admitted to the top of the cell and drawn off the bottom (downflow system), or be admitted to the bottom of the cell and drawn off the top (upflow system). A plastic stock tank was added to the inlet circuit of each subcell to allow additional precipitation of ferric oxyhydroxides from the mine drainage before entry into the cell, thereby minimizing clogging of the system. Changes were also made in the substrates. The original peatbased substrate was replaced by mushroom compost identical to that used in cell $\mathrm{A}$, and no vegetation was transplanted into cell $B$ after it was rebuilt.

At the same time of cell B reconstruction, two new cells were built (fig. 37). Cell D was designed to further treat the effluent of cell $A$ by surface flow. Its dimensions

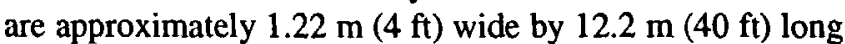
by $45 \mathrm{~cm}(1.5 \mathrm{ft})$ deep. Cell $\mathrm{E}$ was designed as a circular downflow cell, approximately $3.05 \mathrm{~m}(10 \mathrm{ft})$ in diameter by $0.61 \mathrm{~m}(2 \mathrm{ft})$ deep. It was constructed by excavating a small impoundment, lining it with Hypalon, installing a PVC drain at the bottom under a layer of gravel, and placing filter fabric over the gravel. Both cells D and cell E were filled with the peat-based substrate and were planted with vegetation removed from cell $B$. Figure 40 shows the approximate location of all cells at the Big Five Tunnel site.

\section{SUMMARY OF RESULTS}

Although several interrelated studies on the hydrology, microbiology, geochemistry, and vegetation were conducted, only a general summary of cell behavior will be 


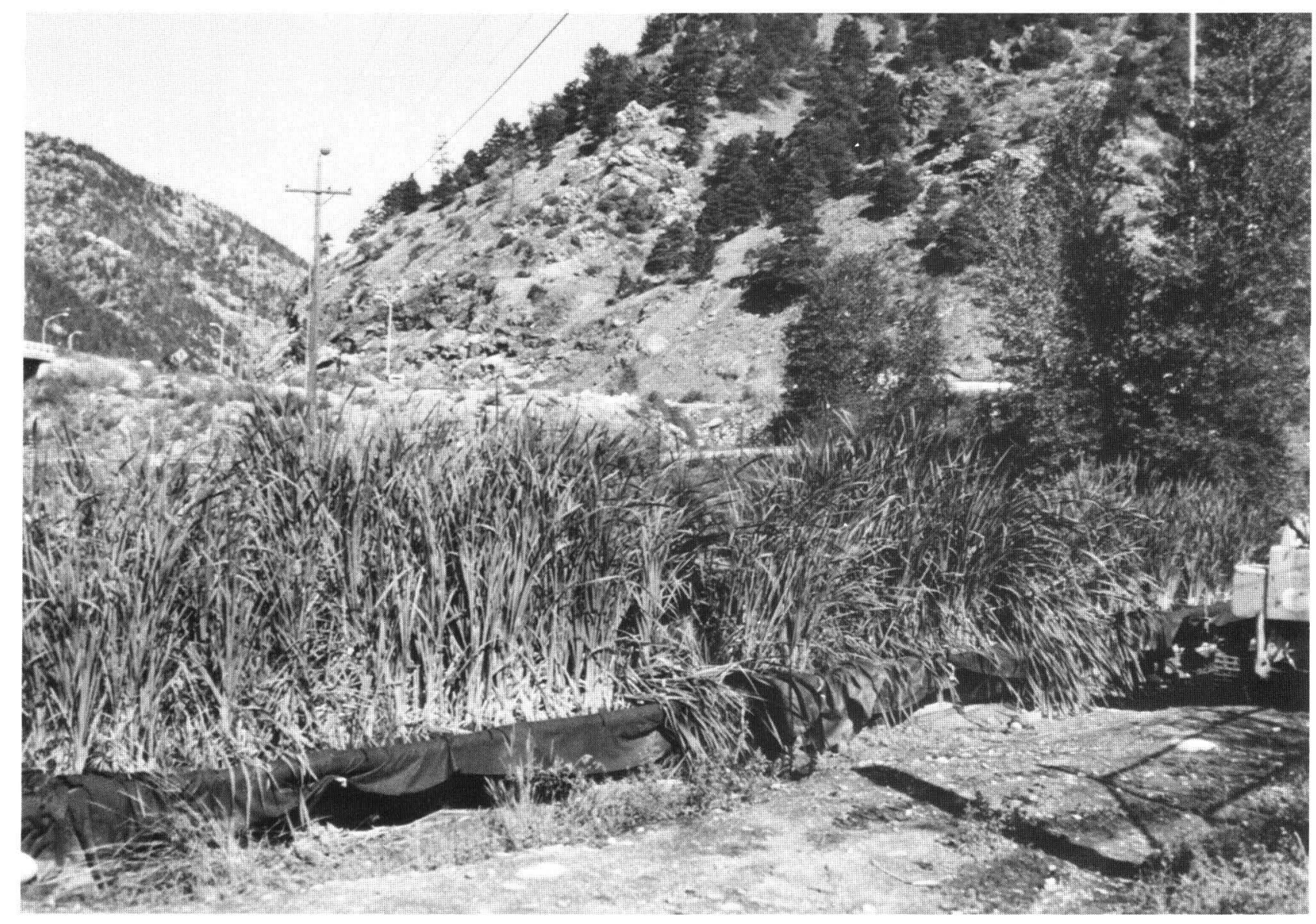

Figure 37. View toward the west of cattails growing in cells A, B, and C of the constructed wetland. Individual cells are not discernible in this photograph. However, the acid-resistant liner fabric, Hypalon, can be seen. Colorado School of Mines photograph (printed with permission).

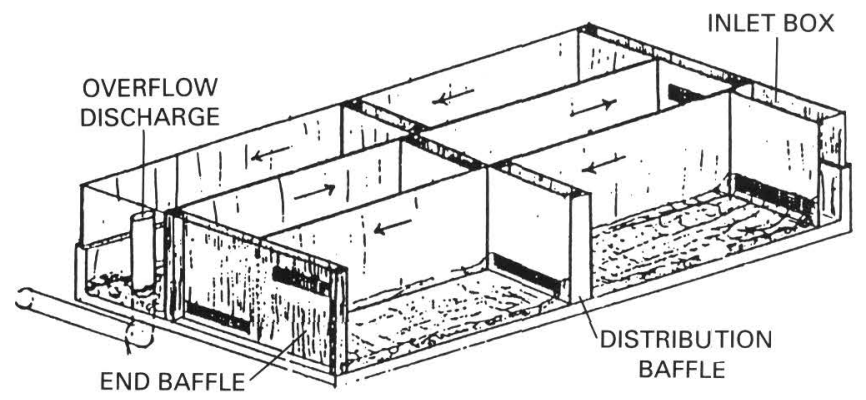

Figure 38. Cutaway view of the modified design of cell A.

discussed here. Table 4 presents data from the 11-month period following the last of the major modifications and shows the percentage removal of manganese, iron, copper, and zinc from the drainage by each cell.

Cell A, in spite of its reconstruction, continued to show poor removal of manganese and iron. This was due in part to the design of the modifications. Some leakage occurred

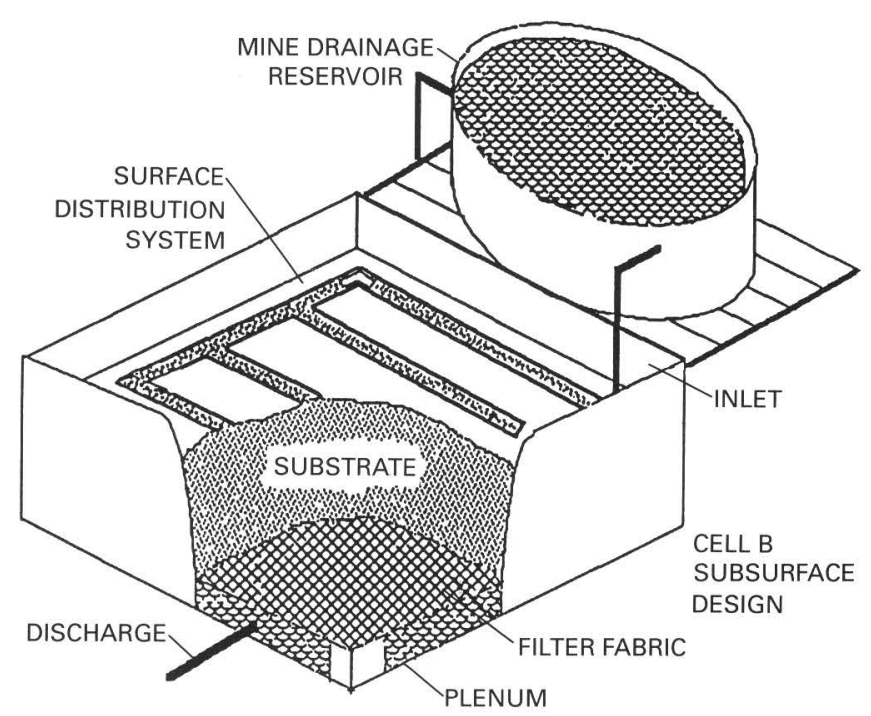

Figure 39. Cutaway view of the modified design of a cell B subcell. 
Table 4. Treatment effectiveness of all cells at the Big Five Tunnel constructed wetland site for selected metals. Data are means of monthly observations and analyses of samples collected during the period from October 1989 through August 1990. Values are shown as the percentage of total metal removed from the mine drainage.

\begin{tabular}{|c|c|c|c|c|c|c|c|}
\hline \multirow[t]{2}{*}{ Cell } & \multirow[t]{2}{*}{$N^{1}$} & $\underline{\mathrm{Mn}}$ & $\mathrm{Fe}$ & $\mathrm{Zn}$ & $\mathrm{Cu}$ & \multirow{2}{*}{$\begin{array}{c}\text { Effluent } \\
\mathrm{pH}\end{array}$} & \multirow{2}{*}{$\begin{array}{l}\text { Flow } \\
\left(\mathrm{L} / \mathrm{min}^{4}\right)\end{array}$} \\
\hline & & \multicolumn{4}{|c|}{ Percentage Removal } & & \\
\hline A (Lateral flow) & 11 & 0.2 & 36 & 61 & 83 & 4.7 & 1.0 \\
\hline$D(\text { Surface flow })^{2}$ & 7 & 13 & 73 & 99 & 100 & 6.3 & 0.84 \\
\hline \multicolumn{8}{|l|}{$B$ (Upflow half) ${ }^{3}$} \\
\hline First 6 months & 10 & 18 & 54 & 52 & 65 & 5.1 & 0.63 \\
\hline Last 6 months & 5 & 34 & 91 & 97 & 100 & 6.8 & 0.34 \\
\hline B (Downflow half) & 11 & 22 & 76 & 40 & 83 & 5.4 & 0.50 \\
\hline$C$ (Lateral flow) & 9 & 2 & 50 & 35 & 65 & 4.4 & 1.0 \\
\hline E (Downflow) & 11 & 10 & 86 & 100 & 97 & 6.2 & 0.51 \\
\hline
\end{tabular}

\footnotetext{
${ }^{1} N$ is the number of monthly observations during the period. Although the total period of observation was 11 months, the number of monthly observations was fewer for cells $\mathrm{C}$ and $\mathrm{D}$ (due to winter freezing problems) and for the upflow half of cell $\mathrm{B}$ (flow problems).

${ }^{2}$ Cell D was receiving the effluent from cell $A$.

${ }^{3}$ Problems with vertical channelization and flow were experienced during the first 6 months of operation. The second row of values reflects the operation of the cell during the last 5 months after the problems were rectified.

${ }^{4}$ Liters per minute.
}

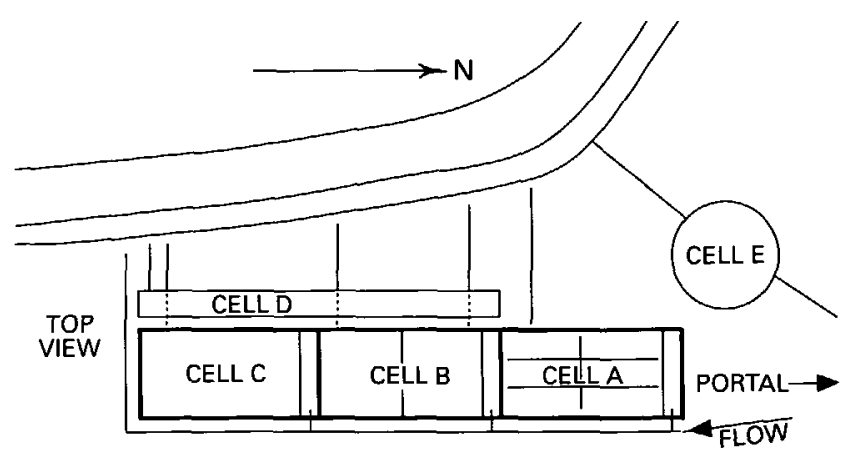

Figure 40. Location of the treatment cells of the Big Five Tunnel system as of spring 1991. around the walls, and clogging of screened ports in the redistribution baffles limited flow in some sections of the system.

The modifications to cell $\mathrm{B}$ which incorporated a vertical flow design produced promising results. It removed more manganese in general than the other cells, as well as a higher proportion of the other elements. The downflow subcell initially performed better. When flow problems were solved in the upflow subcell, however, this cell seemed to produce the best overall performance.

Cell $\mathrm{C}$ is the only cell that remained unmodified since the treatment system was constructed. Although cell $\mathrm{C}$ did not perform as well as the others, it was in operation longer than the rest, and therefore the most data has been accumulated for this cell. Figure 41 (top) shows the percentage removal of manganese, iron, and zinc by cell C from November 1987 through August 1990. The 

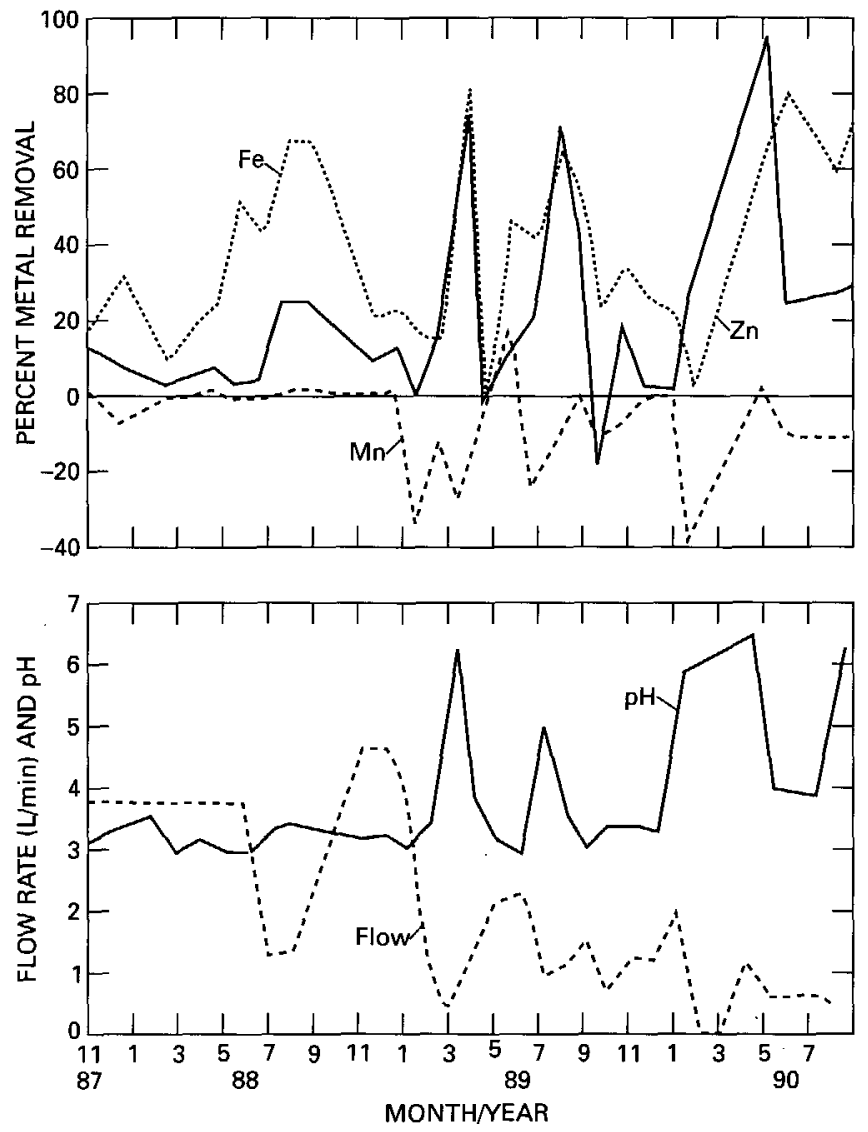

Figure 41. Graph showing treatment effectiveness of cell C. Metal values are shown as percentage of removal compared to concentrations in the mine drainage.

bottom part of figure 41 shows the variation in $\mathrm{pH}$ and effluent flow rate for the same time period. The flow rate for the first 7 months is probably not as constant as shown because it was monitored and adjusted only every few weeks, and the inlet valve was frequently clogged. Beginning in July 1988 , water samples and flow rate measurements were taken simultaneously prior to cleaning of the inlet valve.

Figure 41 shows a relatively clear inverse relationship between flow rate and $\mathrm{pH}$. Lower flow rates are consistent with higher $\mathrm{pH}$, showing removal of acid. Lower flow rates also correlate with higher percent removal of iron and zinc. Although not shown in this figure, the pattern of copper removal is similar to that of zinc. These relationships have been observed in other cells as well.

Manganese behaves differently from the other elements, principally because it precipitates more effectively in an oxidizing environment, rather than in the reducing (oxygen-poor) environment of this treatment system. Manganese will not precipitate in a reducing environment unless the $\mathrm{pH}$ in the wetland increases significantly.

Cell D, which received the output of cell $A$, showed the greatest efficiency for removal of most metals. However, cell $\mathrm{D}$ often froze during the winter because it is a relatively shallow surface flow cell.

Cell $\mathrm{E}$ originally was constructed to utilize substrate and plants left over from the reconstruction of cells B and D. It has been rather effective throughout most of its operation at removing metals and raising $\mathrm{pH}$ of the mine drainage. This is significant because it was less expensive to construct and it may represent a more realistic prototype of future small treatment systems.

\section{CONCLUSIONS}

The studies of the past 3 years of the pilot treatment system have provided a data base to support several conclusions, although ongoing work at Colorado School of Mines and elsewhere may produce results that will modify some statements below.

The two principal methods by which the wetlands treat acid mine drainage are (1) by metal and hydrogen ion $\left(\mathrm{H}^{+}\right.$or proton) adsorption, and (2) by transformation of metals into insoluble compounds. Adsorption of metals onto an organic substrate increases the residence time as a transitional phase but is not important for long-term retention. Adsorption will, however, provide a readily available source of metals for bacterial reactions. Adsorption of metals and protons will also help buffer the wetland to sudden $\mathrm{pH}$ changes (mostly acidic).

The major metal removal in the wetland takes place by the microbially mediated process called dissimilatory sulfate reduction. Certain bacteria use sulfate $\left(\mathrm{SO}_{4}\right)$ present in the mine drainage instead of oxygen $\left(\mathrm{O}_{2}\right)$ as a terminal electron receptor for cellular reactions. These reactions produce hydrogen sulfide, $\left(\mathrm{H}_{2} \mathrm{~S}\right)$, which precipitates metals as metal sulfides thereby removing them from solution. The reactions proceed as long as a reducing environment is maintained and other anaerobic bacteria are present that use organic carbon as a food source. The decomposition of organic matter by anaerobic bacteria releases ammonia $\left(\mathrm{NH}_{3}\right)$, bicarbonate ions $\left(\mathrm{HCO}_{3}{ }^{-}\right)$, and methane $\left(\mathrm{CH}_{4}\right)$ all of which raise the $\mathrm{pH}$ sufficiently for the sulfate reduction to occur.

Metals, such as copper and zinc, can be removed effectively by these processes, iron somewhat less effectively, and $\mathrm{pH}$ can be increased on a long-term basis. Iron removal is a key aspect in the functioning of the system due to the role of iron in forming acidity (fig. 27). In addition, iron plays a key role by its absorption of other metals on its oxides.

Plants function mainly to stabilize the substrate surface, reduce channelization, and provide a source of organic matter for the microbes. Many plant species would probably work well in constructed wetlands, as long as they can tolerate saturated soils, low $\mathrm{pH}$, and high metal concentrations. Ideally, the plants should have high biomass production to provide a suitable source of carbohydrates for 
microbial populations. Although plants absorb metals through their roots, they are relatively unimportant for direct long-term removal of metals. Most of the metals that are absorbed by the plant tissues return to the soil when the plants die and decompose. Of the species studied at the Big Five wetland, cattails worked best. Plants may pump oxygen into the upper part of the wetland, however, thereby producing oxidizing conditions and decreasing the amount of sulfate reduction.

Substrates that buffer to $\mathrm{pH} 5.5$ or higher enhance sulfate reduction and allow a new wetland to function effectively from the beginning. The minimum desirable limits of hydraulic conductivity (rate of water movement) for substrates is $10^{-5} \mathrm{~cm} / \mathrm{sec}^{34}$ The use of peat is, therefore, not advisable because of its tendency to buffer the aqueous phase to low $\mathrm{pH}^{\prime} \mathrm{s}(<5.5)$ and its low hydraulic conductivity $\left(<10^{-5} \mathrm{~cm} / \mathrm{sec}\right)$.

Flow rates were the major limiting factor in our wetland treatment. Lower flow rates were better for metal removal and reduction of acidic "shock" by Big Five Tunnel drainage water to the micro-organisms responsible for sulfate reduction. A vertical saturated-flow design was also more effective than one relying on lateral flow. Circulation through the substrate was poor in the lateral systems because water tended to flow on the surface or cause channelization in the substrate thereby limiting contact of the mine drainage water with the substrate. Both problems were minimized in vertical flow systems.

Removal efficiency depends strongly on the loading factor-a function of flow rate and surface area available for reactions to take place. More than $24 \mathrm{~m}^{2} / \mathrm{L} / \mathrm{min}$ $\left(1000 \mathrm{ft}^{2} / \mathrm{gal} / \mathrm{min}\right)$ was needed for reasonable removal at the Big Five system, assuming a substrate depth of $0.61-$ $1 \mathrm{~m}(2-3 \mathrm{ft})$. Mine drainage with different metal and acid concentrations would require a different volume of substrate. This can be determined by bench-scale tests (laboratory simulation of field tests).

Plumbing should be kept simple to avoid clogging by hydrous ferric oxides; some parts of the treatment cell may need insulation to prevent freezing. Sharp bends and vertical rises are particularly vulnerable to accumulations of iron

\footnotetext{
${ }^{34}$ Centimeters per second, there are about 2.5 centimeters per inch.
}

Published in the Central Region, Denver, Colorado

Manuscript approved for publication September 28, 1993

Graphics by Michael F. Duncan, Margo L. Johnson, Shawn K.

Smith, Richard P. Walker, Norma J. Maes, Arthur L. Isom, and

Carol Quesenberry

Edited by Thomas Kohnen

Photocomposition by Marie Melone precipitates. To minimize freezing, the plumbing of the entire system should be placed in areas that receive winter sun.

\section{ACKNOWLEDGMENTS}

Many people have contributed to the studies at the Big Five Project. These include Dr. David Updegraff, Dr. E.A. Howard, Robin Madel, Margaret Staub, Wafa Batal, Judy Bolis, Larry Chang, John Deitz, Pat Keller, Leslie Laudon, Peter Lemke, Steve Machemer, Mahani Mamat, Leslie Moe, Dee Mohamed, Nita Mohdnoordin, Tom Oliver, Scott Plummer, Julie Reynolds, and Chris Sellstone, of the Colorado School of Mines; Dr. John Gormley and James Gusek of Denver Knight Piesold; Dr. Rick Chappell, Susan Morea, and Dr. Roger Olsen of Camp, Dresser, and McKee; Dr. Edward R. Bates, Holly Fliniau, James Kreissl, Dr. James Lazorchek, and Mark Smith of the U.S. Environmental Protection Agency; and Rick Brown, Jeff Deckler, and Jeb Love of the Colorado Department of Health. The involvement and cooperation of all these individuals is appreciated and attests to the multidisciplinary nature of this project.

\section{REFERENCES}

Benjamin, M.M., and Leckie, J.O., 1981, Competitive adsorption of $\mathrm{Cd}, \mathrm{Cu}, \mathrm{Zn}$, and $\mathrm{Pb}$ on amorphous iron oxyhydroxide: Journal of Colloid and Interface Science, v. 83, p. 410-419.

Hammer, Donald, A., ed., 1989, Constructed wetlands for wastewater treatment-municipal, industrial, and agricultural: Boca Raton, Florida, Lewis Publishers, Inc., 831 p.

Herlihy, Alan T., and Mills, Aaron L., 1985, Sulfate reduction in freshwater sediments receiving acid mine drainage: Applied and Environmental Microbiology, v. 49, p. 179-186.

Kerndorf, H. and Schnitzer, M., 1980, Sorption of metals onto humic acid: Geochimica et Cosmochimica Acta, v. 44, p. 1701-1708.

Wakao, Norio, Takahashi, T., Sakuria, Y., and Shiota, H., 1979, A treatment of acid mine water using sulfate-reducing bacteria: Journal of Fermentation Technology, v. 57, p. 455-452.

Wildeman, T.R., Brodie, G.A., and Gusek, J.J., 1992, Wetland Design for Mining Operations: Vancouver, B.C., Bitek Publishers, $400 \mathrm{p}$.

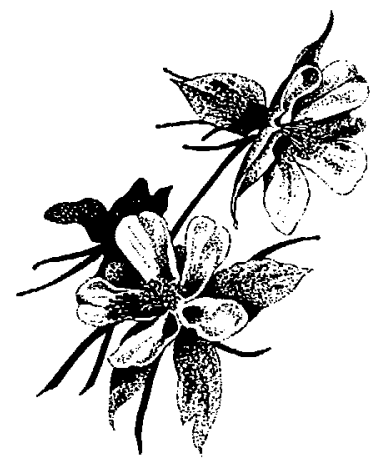






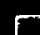

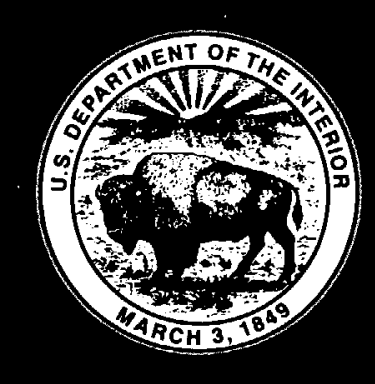

